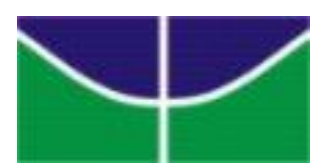

UNIVERSIDADE DE BRASÍLIA - UnB FACULDADE UnB PLANALTINA - FUP

PROGRAMA DE PÓS-GRADUAÇÃO EM MEIO AMBIENTE E DESENVOLVIMENTO RURAL

DIMENSÕES DA AGROECOLOGIA NA PRODUÇÃO E COMERCIALIZAÇÃO DE AGRICULTORES FAMILIARES NO DISTRITO FEDERAL E ENTORNO

NÁDIA SILVÉRIO OLIVEIRA IRINEU

Brasília

2016 


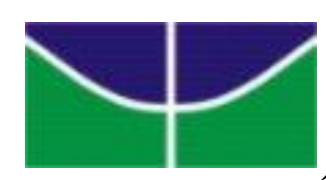

UNIVERSIDADE DE BRASÍLIA - UnB

FACULDADE UnB PLANALTINA - FUP

PROGRAMA DE PÓS-GRADUAÇÃO EM MEIO AMBIENTE E DESENVOLVIMENTO RURAL

\section{DIMENSÕES DA AGROECOLOGIA NA PRODUÇÃO E COMERCIALIZAÇÃO DE AGRICULTORES FAMILIARES NO DISTRITO FEDERAL E ENTORNO}

NÁDIA SILVÉRIO OLIVEIRA IRINEU

ORIENTADORA: JANAÍNA DEANE DE ABREU SÁ DINIZ CO-ORIENTADORA: VÂNIA FERREIRA ROQUE-SPECHT DISSERTAÇÃO DE MESTRADO EM MEIO AMBIENTE E DESENVOLVIMENTO RURAL 
IRINEU, Nádia Silvério Oliveira. Dimensões da agroecologia na produção e comercialização de agricultores familiares no Distrito Federal e Entorno. Brasília: Faculdade UnB Planaltina, Universidade de Brasília, 2016, 94 p. Dissertação de Mestrado.

Documento formal autorizando reprodução desta dissertação de mestrado para empréstimo ou comercialização, exclusivamente para fins acadêmicos, foi passado pelo autor à Universidade de Brasília e acha-se arquivado na Secretaria do Programa. O autor reserva para si os outros direitos autorais de publicação. Nenhuma parte desta dissertação de mestrado pode ser reproduzida sem a autorização por escrito do autor. Citações são estimuladas, desde que citada a fonte.

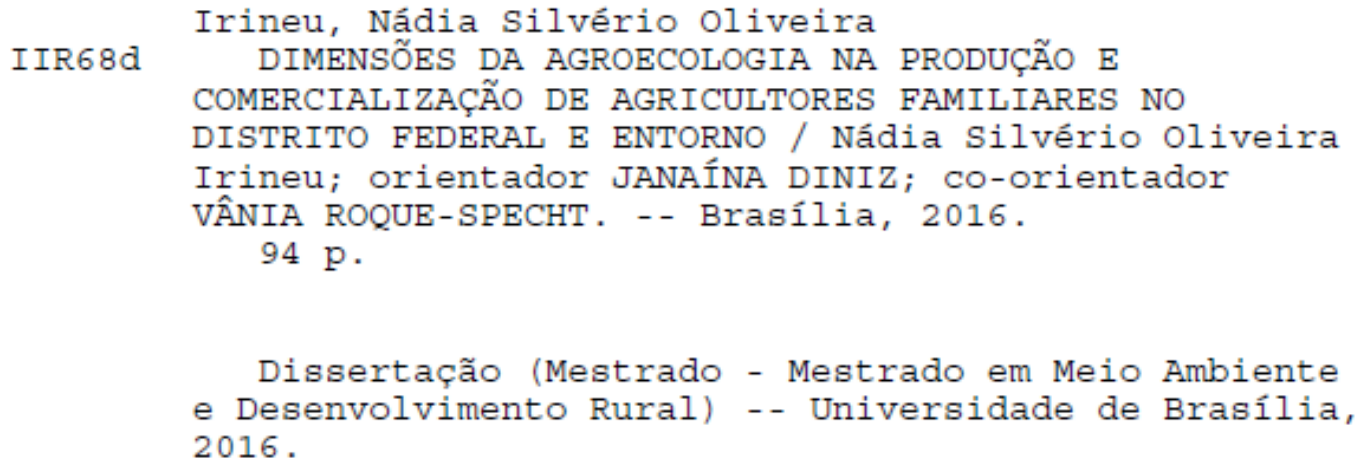

1. Agroecologia. 2. Dimensões da agroecologia. 3. Sistemas agroflorestais. 4. Agricultura familiar. I. DINIZ, JANAÍNA, orient. II. ROQUE-SPECHT, VÂNIA, co orient. III. Título. 
UNIVERSIDADE DE BRASÍLIA - UnB

FACULDADE UnB PLANALTINA - FUP

PROGRAMA DE PÓS-GRADUAÇÃO EM MEIO AMBIENTE E

DESENVOLVIMENTO RURAL

Termo de Aprovação

\title{
DIMENSÕES DA AGROECOLOGIA NA PRODUÇÃO E COMERCIALIZAÇÃO DE AGRICULTORES FAMILIARES NO DISTRITO FEDERAL E ENTORNO
}

\author{
NÁDIA SILVÉRIO OLIVEIRA IRINEU \\ DISSERTAÇÃO DE MESTRADO SUBMETIDA \\ AO PROGRAMA DE PÓS-GRADUAÇÃO EM \\ MEIO AMBIENTE E DESENVOLVIMENTO \\ RURAL, COMO PARTE DOS REQUISITOS \\ NECESSÁRIOS À OBTENÇÃO DO GRAU DE \\ MESTRE EM MEIO AMBIENTE E \\ DESENVOLVIMENTO RURAL
}

APROVADO POR:

JANAÍNA DEANE DE ABREU SÁ DINIZ, DOUTORA (FUP - UnB) (ORIENTADORA)

MOISÉS VILLAMIL BALESTRO, DOUTOR (FUP - UnB) (EXAMINADOR INTERNO)

MARIANE CARVALHO VIDAL, DOUTORA (EMBRAPA Hortaliças) (EXAMINADOR EXTERNO)

LAURA MARIA GOULART DUARTE, DOUTORA (FUP - UnB) (MEMBRO SUPLENTE)

BRASÍLIA/DF, 27 DE MAIO DE 2016 
Retrato do artista quando coisa

\author{
A maior riqueza \\ do homem \\ é sua incompletude. \\ Nesse ponto \\ sou abastado. \\ Palavras que me aceitam \\ como sou \\ - eu não aceito. \\ Não aguento ser apenas \\ um sujeito que abre \\ portas, que puxa \\ válvulas, que olha o \\ relógio, que compra pão \\ às 6 da tarde, que vai \\ lá fora, que aponta lápis, \\ que vê a uva etc. etc. \\ Perdoai. Mas eu \\ preciso ser Outros. \\ Eu penso \\ renovar o homem \\ usando borboletas.
}

\title{
Manoel de Barros
}

Dedico esse trabalho às pessoas mais importantes do mundo pra mim: minha família! 


\section{AGRADECIMENTOS}

Eu sou grata a esse momento de vida que me deu a oportunidade, o tempo e o espaço para realizar o mestrado. Sou grata ao grande Arquiteto Universal por permitir tudo o que aconteceu, o que acontece e o que acontecerá na minha vida e na natureza.

Sou grata aos meus pais, Geraldo e Leny, ambos professores de exatas, por me ensinarem desde cedo os valores que carrego até hoje, por me incentivarem sempre e por terem investido tanto na minha educação.

Sou grata aos meus irmãos, Filipe e Ariádne, pela companhia e incentivo.

Sou grata ao meu consorte, Adauto, por compreender minha ausência em muitos momentos e, principalmente, pelo respeito e amor.

Sou grata à orientação da professora Janaína Diniz e da professora Vânia Roque-Specht que me indicaram caminhos e fizeram o que foi possível para me auxiliar. Sou grata até pelos puxões de orelha.

Sou grata às contribuições valorosas dos professores Moisés Balestro e Laura Duarte na banca de qualificação que me permitiu visualizar de forma mais clara os rumos da pesquisa.

Sou grata pela participação e contribuição na banca de defesa da pesquisadora Mariane Vidal e (novamente) do professor Moisés Balestro, que me conhece desde a graduação e sinto que me incentivou desde aquela época.

Sou grata à Maria Cristina Madeira, que pôde flexibilizar meus horários de trabalho para que eu pudesse concluir os créditos das disciplinas e posteriormente ir para a pesquisa de campo com mais tempo. Sou grata pelos livros emprestados, pelas dicas, conversas e principalmente pelo apoio e amizade.

Sou grata aos colegas do MADER que caminharam e cresceram junto comigo nesses dois anos de aprendizado coletivo. Em especial, as amigas Juliana e Thaís, que também me acompanhou em uma visita de campo.

Sou grata aos meus primos, Tainah e Eduardo, que traziam leveza e risadas a alguns dias que pareciam exaustivos.

Sou grata a todos os meus amigos que me emprestavam seus ouvidos e às vezes os ombros.

Sou grata à disposição dos agricultores Maurício, Juã, Valdir e Wátila que me atenderam com boa vontade e carinho. Eu aprendi um tanto pelo exemplo de vida dessas pessoas que têm um ofício tão bonito de vender vida em forma de folhas, frutas e verduras. De uma forma tão humana de entender e trabalhar com a natureza.

Sou grata a todos os acontecimentos que me fizeram perceber como eu me encontrava no início do mestrado e como me encontro agora concluindo essa etapa, não só acadêmica, mas de vida.

Sou grata a todos que de alguma maneira me auxiliaram nessa trajetória.

Minha profunda gratidão. 
"L'amor che move il sole e l'altre stelle".

(O amor que move o sol e as outras estrelas)

Dante Alighieri 


\section{RESUMO}

A agroecologia é um campo de conhecimento científico que fornece as bases para enfrentar a crise ecológica e social, por vezes advinda do modelo de agricultura empresarial que hoje é predominante no mundo. Alguns agricultores familiares no Brasil e no mundo vêm produzindo de forma agroecológica alimentos livres de agrotóxicos, aumentando a biodiversidade e beneficiando o planeta. Dessa forma, esta dissertação apresenta estudo de caso com quatro agricultores familiares do Distrito Federal e Entorno que produzem e comercializam de forma orgânica/agroecológica. Trata-se de pesquisa qualitativa, a partir de estudo de casos múltiplos, por meio da qual foram realizadas visitas às propriedades e entrevistas semiestruturadas com base em cinco dimensões da agroecologia: ambiental, escala, econômica, social e política. A partir da literatura existente sobre agricultura familiar, agroecologia e dimensões da agroecologia foi realizada uma análise crítica comparativa dos dados coletados na pesquisa de campo com os dados existentes na literatura sobre o tema. Os quatro agricultores produzem por meio da técnica de Sistemas Agroflorestais (SAFs) e escoam a produção principalmente em feiras orgânicas, além de participarem de mercados institucionais como o Programa de Aquisição de Alimentos (PAA) e o Programa de Aquisição da Produção da Agricultura do DF (PAPA/DF). Houve diferentes justificativas - relacionadas às dimensões da agroecologia - quanto à autodenominação dos entrevistados como agricultores orgânicos e/ou agroecológicos. O volume de produção apresentado indica que eles conseguem manter uma constância na oferta dos produtos nos lugares onde comercializam, além de conseguirem organizar esquemas informais de troca de produtos entre eles. Os quatro agricultores demonstraram forte comprometimento com a produção ecológica, com o respeito à natureza e têm a pretensão de continuar trabalhando com agricultura orgânica/agroecológica no futuro.

Palavras-chaves: dimensões da agroecologia, agroecologia, sistemas agroflorestais, agricultura familiar. 


\begin{abstract}
The science of Agroecology offers an alternative to the model of commercial agriculture that currently predominates. In Brazil and in the world, many family farms have been producing agrotoxin-free food in an agroecological way, increasing biodiversity and benefiting the planet. This dissertation presents a case study of four family farms in and around the Federal District (DF) of Brazil, which use organic and agroecological production and commercialization systems. The present qualitative study realized visits to these farms and semi-structured interviews, based on five agroecological dimensions: environment, scale, economy, social and politics. A critical analysis of data collected in the field was realized based on the current literature on family farms, agroecology and agroecological dimensions. It was found that, the four family farmers use agroforestry systems as their form of production. Organics fairs are their main form of commercialization, while also selling at institucional markets including the Food Acquisition Programme (PAA) and the DF Food Production Acquisition Programme (PAPA-DF). In relation to their type of production, whether organic or agroecological, disparities between the family farms, were found. Production volume indicated that each farm offers a constant amount products at their commercial locations, in addition to organizing informal exchanges that supplement the necessity of farmers who may be in need of produce at their organic fair. The four family farms expressed strong involvement with ecological production, environmental respect and share the perspective of continuing to work through organic/agroecological methods in the future.
\end{abstract}

Key-words: dimensions of the agroecology, agroecology, agroforestry systems, family farmers 


\section{LISTA DE FIGURAS}

Figura 01. Municípios brasileiros por percentual de estabelecimentos com agricultura familiar

Figura 02. Dimensões da sustentabilidade pela agroecologia abordadas na dissertação

Figura 03. Volume de comercialização de frutas, legumes, raízes e folhagens dos agricultores A, B, C e D.

Figura 04. Canais de comercialização do Agricultor Familiar A

Figura 05. Canais de comercialização do Agricultor Familiar B

Figura 06. Canais de comercialização do Agricultor Familiar C

Figura 07. Canais de comercialização do Agricultor Familiar D

\section{LISTA DE MAPAS}

Mapa 01. Localização das propriedades dos agricultores familiares da pesquisa no DF e Entorno.

\section{LISTA DE QUADROS}

Quadro 01. Agriculturas Alternativas

Quadro 02. Utilização das terras nos estabelecimentos segundo a agricultura familiar

Quadro 03. Breve comparativo entre os sistemas de cultivo orgânico e convencional

Quadro 04. Políticas públicas (PAA, PAPA-DF, PRONAF, Mais Alimentos e Prospera) acessadas pelos agricultores familiares no DF e Entorno.

Quadro 05. Principais fontes de renda dos agricultores A, B, C e D.

\section{LISTA DE TABELAS}

Tabela 01. Evolução da produção orgânica do Distrito Federal 


\section{LISTA DE ABREVIATURAS E SIGLAS}

ACI - Assentamento Colônia I

AGE - Associação de Agricultura Ecológica

APP - Área de Preservação Permanente

Asprosaf - Associação dos produtores agroflorestais

CAR - Cadastro Ambiental Rural

CC - Circuitos curtos de comercialização

CEASA - Central de Abastecimento do Distrito Federal

Codeplan - Companhia de Planejamento do Distrito Federal

CONAB - Companhia Nacional de Abastecimento

Coopafama - Cooperativa de agricultores agroecológicos do Assentamento Colônia I

DF - Distrito Federal

Emater - Empresa Brasileira de Assistência Técnica e Extensão Rural

EMBRAPA - Empresa Brasileira de Pesquisa Agropecuária

FAO - Organização das Nações Unidas para Alimentação e Agricultura

FOEB - Feirinha Orgânica da Estação Biológica

GTRA - Grupo de trabalho de apoio à Reforma Agrária

GVP - Grupo Vida e Preservação

IBGE - Instituto Brasileiro de Geografia e Estatística

ICC - Instituto Central de Ciências

INCRA - Instituto Nacional de Colonização e Reforma Agrária

MAPA - Ministério da Agricultura

MDA - Ministério do Desenvolvimento Agrário

PAA - Programa de Aquisição de Alimentos da Agricultura Familiar

PAPA/DF - Programa de Aquisição da Produção da Agricultura

PIB - Produto Interno Bruto

PLANAPO - Plano Nacional de Agroecologia e Produção Orgânica

PNAE - Programa Nacional de Alimentação Escolar

PNAPO - Política Nacional de Agroecologia e Produção Orgânica

PRONAF - Programa Nacional de Fortalecimento da Agricultura Familiar

PROSPERA - Programa de Microcrédito Produtivo Orientado do Governo do Distrito Federal

SAF - Secretaria da Agricultura Familiar

SAFs - Sistemas Agroflorestais 


\section{SUMÁRIO}

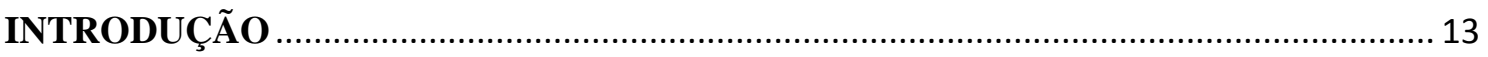

CAPÍTULO I - AGRICULTURA FAMILIAR NO CONTEXTO BRASILEIRO ….......... 20

1.1. BREVES CONSIDERAÇÕES HISTÓRICAS SOBRE O DESENVOLVIMENTO DA

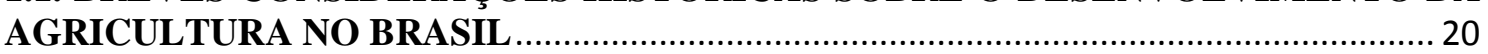

1.2. CONCEITUANDO A AGRICULTURA FAMILIAR NO BRASIL ............................. 22

1.3. AGRICULTURA FAMILIAR NO DISTRITO FEDERAL ......................................... 26

1.3.1 Considerações sobre algumas políticas públicas da agricultura familiar ................... 29

CAPÍTULO II - AGROECOLOGIA: A ECOLOGIA DOS SISTEMAS AGRÍCOLAS ... 34

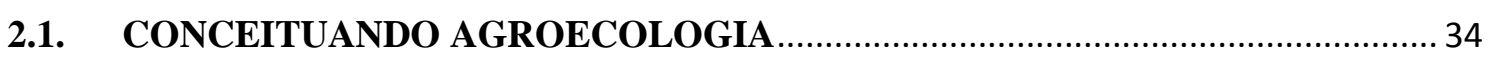

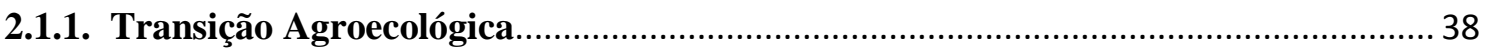

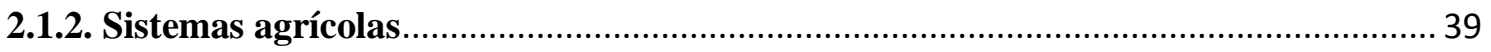

2.2. UM OLHAR SOBRE OS MERCADOS AGROECOLÓGICOS E ORGÂNICOS NO

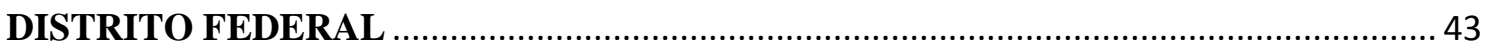

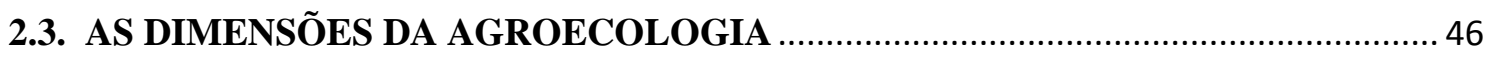

CAPÍTUlo III - AS DIMENSÕES DA AGROECOLOGIA PELA PRÁtica dOS

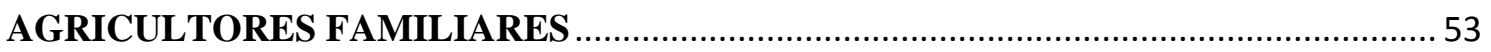

3.1. CARACTERIZAÇÃO DAS PROPRIEDADES DOS AGRICULTORES ................ 55

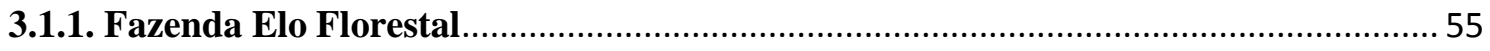

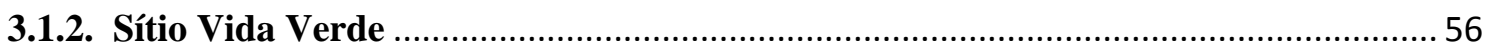

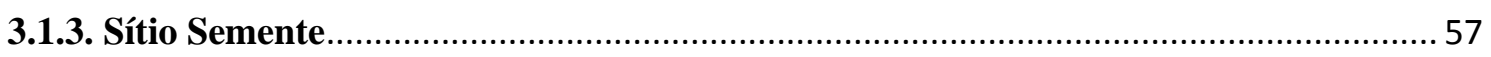

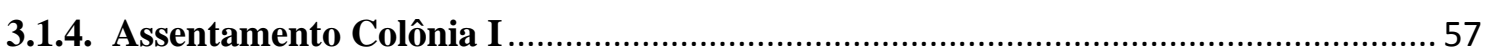

3.2 CONSIDERAÇÕES SOBRE AS DIMENSÕES DA AGROECOLOGIA PELOS

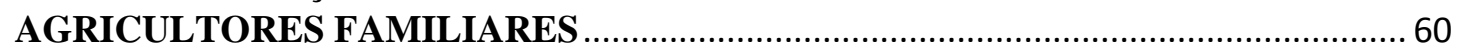

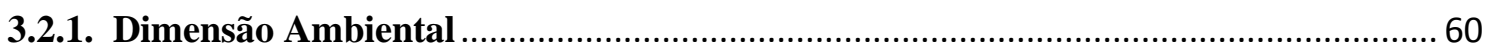

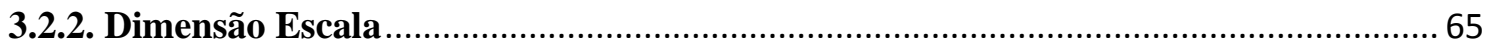

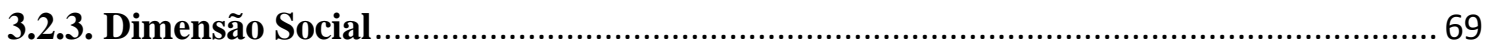

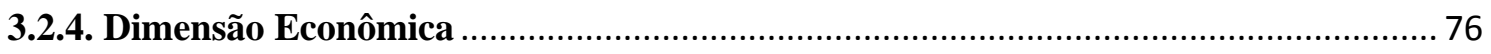

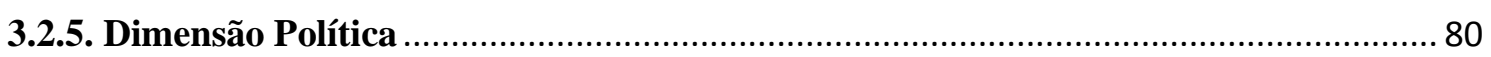

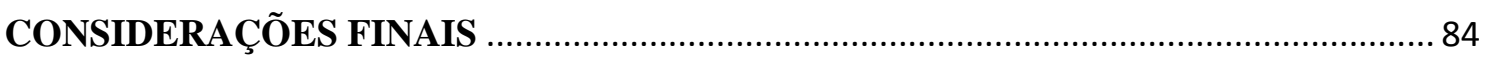

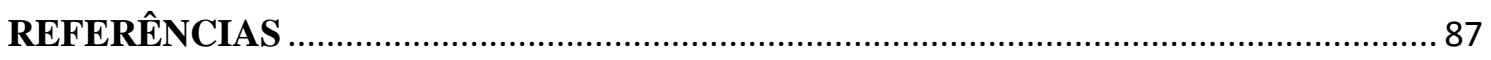

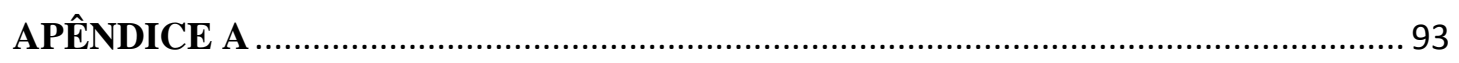

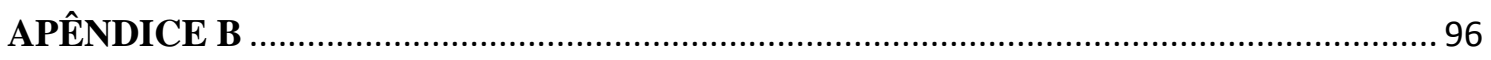




\title{
INTRODUÇÃO
}

A Revolução Verde, como foi denominado o pacote de inovações tecnológicas na agricultura, iniciou-se nos anos 1940 no México (SAUER e BALESTRO, 2009). Mas teve seu maior desenvolvimento tecnológico e uma maior disseminação nos Estados Unidos, entre o final dos anos 60 e início dos 70, impulsionada pelos avanços nas pesquisas genéticas e também nas áreas de química, mecânica e do próprio desenvolvimento do setor industrial agrícola. Assim, a modernização agrícola, mesmo alcançando inegáveis padrões altos de produtividade, não respeitava a integridade do meio ambiente e, portanto, sujeitava-se às perspectivas econômicas de curto prazo, segundo Petersen (2009, p.6):

\begin{abstract}
A modernização baseada nos preceitos técnico-científicos da Revolução Verde introduziu mudanças substanciais nas formas de gestão técnica e econômica dos sistemas agrícolas, [...] A industrialização da agricultura induziu processos de especialização produtiva; a disseminação do empreendedorismo baseado na economia de escala; e uma forte dependência da agricultura a insumos comerciais e a mercados de produtos dominados por grandes complexos agroindustriais. [...] cujo traço mais caracterizado é uma racionalidade econômica movida pelas expectativas de curto prazo para a recuperação do capital investido, em detrimento de quaisquer preocupações com o bem-estar social e com a integridade do meio ambiente.
\end{abstract}

Chegou no Brasil apenas em 1970, devido a incentivos governamentais, com crédito barato e criação de uma rede pública de assistência técnica e extensão rural, além da criação também de cursos universitários e técnicos para a disseminação do pacote tecnológico (SAUER e BALESTRO, 2009). Os impactos negativos da Revolução Verde ao longo do tempo incluem desde a redução da biodiversidade, o estreitamento da base genética dos alimentos, ênfase nos monocultivos e na produção de commodities até os impactos ambientais como as mudanças climáticas, contaminação da camada de ozônio e contaminantes químicos na cadeia alimentar humana (CAPORAL, 2009).

No Brasil, como os recursos públicos àquela época estavam voltados à disseminação do pacote tecnológico para a produção monocultora de grande escala, houve a exclusão de grande parte dos agricultores familiares. Assim, a atual realidade fundiária e agrária do país teve como base essa produção monocultural em larga escala financiada com recursos públicos (SAUER e BALESTRO, 2009).

O modo de produção vigente, da agricultura industrializada, com cadeias produtivas detalhadas e atendendo a pré-requisitos estabelecidos pelas indústrias de 
processamento e também pelas grandes cadeias de varejo, acaba por padronizar a cadeia alimentar. Assim, consequentemente afeta pequenos agricultores familiares, que muitas vezes não conseguem atender a todos os critérios impostos, e assim por vezes não conseguem competir com os agricultores de larga escala. Dessa forma, Darolt (2013) sugere que uma das soluções para essa competição desigual seria a aproximação da comunidade urbana da rural, impulsionando a comercialização de produtos de base ecológica. A agricultura, assim como as relações ecológicas e sociais envolvidas na produção, no processamento e no consumo de alimentos, pode ser também um espaço para o estudo da interação entre os problemas sociais e ecológicos do mundo (SCHMITT, 2001).

Van der Ploeg (2008a) destaca que há três processos de transição que estão remodelando a agricultura: a industrialização, o recampesinato e a desativação (tradução livre). A industrialização da agricultura é multidimensional e um processo de múltiplos níveis. O maior exemplo disso é a expansão territorial das propriedades e consequente aumento da escala ${ }^{1}$. Essa industrialização causa a desconexão entre o ato de produzir e a própria produção com a natureza, a partir do momento em que o capital ecológico é substituído pelo capital industrial e financeiro. O recampesinato, por sua vez, representa o retorno ao capital ecológico por meio da construção ativa de novos degraus de autonomia como as novas relações com o consumidor a partir da venda direta, e o engajamento em novas redes que ligam a cidade com o campo. A desativação representa a diminuição das atividades agrícolas e frequentemente o aumento de outras atividades econômicas com o objetivo de desenvolver o campo como um 'espaço de consumo', exemplificados (não somente) pelos espaços de lazer e reservas naturais.

É necessário destacar também três grupos de formas de agricultura: capitalista, empresarial e camponesa. Em uma explicação mais generalista, a agricultura capitalista se refere ao agronegócio de modelo exportador; a agricultura empresarial se refere àquela que é dependente do mercado, investe nos insumos, é um pouco mais capitalizada e pode ser capitaneada por um empresário que investe no campo; por fim a agricultura camponesa se refere à clássica agricultura de subsistência, que tem como característica principal a multifuncionalidade, se baseia no uso sustentável do capital ecológico (VAN DER PLOEG, 2008b).

\footnotetext{
${ }^{1}$ Van der Ploeg (2008a) conceitua escala como a relação entre o volume de produção e a força de trabalho.
} 
O movimento da agricultura agroecológica promove standards ${ }^{2}$ compatíveis com a agricultura familiar, dessa forma, ganha força ao contrapor e ser uma alternativa aos standards dominantes. Assim a agricultura familiar está em processo de adaptação a esses standards, ao mesmo tempo em que se mobilizam para conseguir um novo standard que seja compatível com suas condições técnicas e econômicas (WILKINSON, 2008). Nessa linha de raciocínio, a agroecologia aparece como um possível caminho para o desenvolvimento rural, como ressalta Altieri (2004, p.36):

O enfoque da agroecologia é nos agricultores com poucos recursos, isto é, aqueles que têm o menor acesso aos insumos tecnológicos e poucas relações com o mercado. A agroecologia vê esses agricultores como o ponto de partida para uma estratégia de desenvolvimento rural sustentável.

A agroecologia, depois do surgimento da agricultura alternativa e outras correntes de agriculturas sustentáveis, surge como mais um caminho alternativo e também como um campo de conhecimento científico que fornece as bases para enfrentar a crise ecológica e social pós-Revolução Verde. A intenção da Agroecologia é resumida por Comunello (2010, p.2):

\begin{abstract}
Na proposta agroecológica, grosso modo, a intenção é de produzir alimentos livres de agrotóxicos e fertilizantes químicos, sem o uso de sementes melhoradas geneticamente ou transgênicas, com baixo uso de derivados do petróleo, em um ambiente biodiverso, por agricultores locados em pequenas unidades. Além disso, em determinados momentos, esses movimentos pretenderam e/ou pretendem questionar muito mais do que apenas um modelo moderno de agricultura, predominante, mas os próprios padrões da moderna sociedade.
\end{abstract}

As questões ambientais referentes à crise alimentar, mudanças climáticas e um possível esgotamento dos combustíveis fósseis elevam o debate sobre a transição agroecológica e a reconstrução do sistema agroalimentar ao nível mundial (SCHMITT, 2009).

A agroecologia é um tema que vem crescendo nas últimas décadas, mas que, mesmo assim, ainda possui uma literatura incipiente que abranjam além dos aspectos técnicos e de sistemas de produção. Desse modo, esse estudo procura contribuir a partir de um recorte de outros aspectos, como os sociais, econômicos, políticos e ambientais, a

\footnotetext{
${ }^{2}$ Wilkinson (2008) traz a palavra standard que em uma tradução livre significa 'padrão', se referindo ao conjunto de exigências que o setor privado impõe tais como condições sanitárias, rastreabilidade, qualidade da água e medidas de ordem ambiental.
} 
fim de colaborar com a análise do panorama da agroecologia no Distrito Federal (DF) e, assim, colaborar com o panorama geral do tema no país.

\section{Problema de pesquisa}

A produção agrícola mundial hoje é capaz de alimentar todo o planeta, erradicando a fome e a desnutrição. E os agroecossistemas, de uma forma geral, produzem alimentos suficientes para que cada habitante do planeta consuma $2.807 \mathrm{kcal}$, o que é um valor acima do mínimo convencionado. Mesmo assim, existem 790 milhões de indivíduos que sofrem com desnutrição crônica e ainda 1.200 milhões de indivíduos que não tem o mínimo de alimentos para sobreviver (MOLINA, 2009).

O Brasil tem muito a contribuir por sua vasta biodiversidade e produção agrícola, porém ainda se divide principalmente entre o modelo químico-dependente agroexportador com uma produção monocultora em larga escala e os agricultores familiares, que ainda são responsáveis por boa parte do abastecimento agrícola interno.

É sabido que mesmo dentro da categoria da agricultura familiar há heterogeneidade no sentido de agricultores que plantam em sistemas monoculturais, assim como agricultores familiares capitalizados e até integrados a cadeias produtivas do agronegócio. Na dissertação trabalharemos com os agricultores familiares com mãode-obra familiar e que produzem em sistemas agroflorestais com base nos princípios agroecológicos. Assim destaca Sachs (2001, p. 263):

\footnotetext{
Graças à sua reserva de terras cultiváveis, variedade de climas e extraordinária biodiversidade, o Brasil é ainda um país de fronteira agrícola. Para o bem ou para o mal? Se partir unicamente para a monocultura de grãos, criará quanto muito um par de milhões de empregos novos e, segundo tudo indica, consolidará a sua posição de país campeão de concentração de renda e de desigualdades sociais abissais. Se conseguir, no entanto, um padrão mais equilibrado de product-mix com forte participação de hortigranjeiras, frutas, culturas perenes de produtos tropicais e produções agroflorestais, gerará muitos milhões de empregos diretos e indiretos, acionando a espiral virtuosa de crescimento a partir de dentro.
}

Essa citação de Sachs (2001) continua atual, pois o Brasil ainda é um país de fronteira agrícola, mas que vem crescendo em pesquisa e produção agroecológica e podemos verificar a contribuição de vários agricultores familiares nesse sentido, inclusive neste trabalho.

O modelo hegemônico de agricultura de larga escala baseado em monoculturas, principalmente de cereais, não traz benefícios em aspectos de biodiversidade, produtividade sustentável e segurança alimentar. Assim como destaca Caporal (2009, p.268): 
Com o atual modelo de desenvolvimento rural e agrícola, será impossível parar os processos de destruição de nossos biomas, pela simples análise histórica do que vem ocorrendo ao longo das últimas cinco décadas. Ou seja, o avanço sobre as chamadas fronteiras agrícolas é consequência inevitável de um modelo que exige mais escala de produção, mais área contínua de monoculturas, mais concentração de terra e, portanto, mais destruição do meio ambiente.

O sistema econômico vigente tem como premissa básica o consumo e a maximização do lucro. A agricultura industrializada, capitalizada e patronal é parte essencial desse sistema que serve principalmente para alimentar os países ainda descritos como desenvolvidos, em detrimento ao restante do planeta. Assim, a agroecologia vem não somente como uma alternativa de produção de alimentos limpos e sustentáveis, mas também com uma proposta de uma nova forma de consumir e interagir com a natureza. São ideias e processos que podem dar base a uma quebra de paradigma e um novo modelo de sociedade. Arl (2008, p.161) nos traz a seguinte compreensão:

\footnotetext{
A agroecologia desafia a fusão da ciência, projeto e processo, propondo uma nova inserção e relação ecológica necessária para uma relação produtiva sustentável, e, ao mesmo tempo, partilha de novas condições e relações sociais e econômicas entre os humanos, em um novo projeto de sociedade. Trata-se de uma nova identidade biológica que insere a espécie humana como parte da natureza (uma nova identidade como espécie), associada a uma nova identidade sociopolítica.

Essa fusão de projeto e processo confere à agroecologia uma dimensão estratégica, ou seja, muito mais do que uma estratégia de resistência e sobrevivência, ela é uma importante tarefa de quebra de paradigmas na construção de uma nova ordem existencial.
}

Ao contrário dos sistemas produtivos convencionais, que tentam controlar o ambiente agrícola ao mesmo tempo em que simplificam as redes de interações ecológicas por meio de insumos externos e energia não renovável, a agroecologia busca estudar os agroecossistemas para desenvolver sistemas que intensifiquem os fluxos e ciclos naturais dos sistemas de produção (MARCO REFERENCIAL EM AGROECOLOGIA - EMBRAPA, 2006).

Devido à existência de diversos enfoques sobre a agroecologia, torna-se um desafio elaborar políticas públicas que consigam atender de forma satisfatória aos anseios dos agricultores familiares e da sociedade. É necessário que se estude melhor como se dá a prática da agroecologia nas propriedades e como ela reflete nos consumidores e, de uma forma geral, qual a sua contribuição para o desenvolvimento rural sustentável. Destacando-se o texto de Schmitt (2009, p.186): 
A construção de interfaces entre o conhecimento produzido a partir de práticas concretas de manejo de agroecossistemas em contextos sociais e ambientais específicos e a constituição de um campo dos conhecimentos que busca proporcionar "as bases científicas para apoiar o processo de transição do modelo convencional para estilos de agricultura de base ecológica ou sustentável" é um processo complexo, que envolve pontos críticos de interseção entre distintas visões de mundo, implicando em descontinuidades e assimetrias em termos de valores, conhecimentos, interesse e poder entre os diferentes agentes envolvidos. Coloca-se nesse sentido, como um desafio para a agroecologia, enquanto abordagem que busca promover um diálogo de saberes, desenvolver um referencial teórico e prático capaz de dar conta da heterogeneidade do conhecimento, da agência humana e da complexidade das redes que dão suporte à produção e reprodução de determinados modos de organização da agricultura e do desenvolvimento rural.

A investigação a que este trabalho se propõe tem como principal foco os agricultores familiares no Distrito Federal envolvidos na temática agroecológica/orgânica. Pretende-se averiguar quais fatores levam esses agricultores familiares a produzir e comercializar produtos agroecológicos/orgânicos no Distrito Federal.

O objetivo geral desta dissertação é analisar em que medida as dimensões da agroecologia são incorporadas/identificadas no sistema produtivo dos agricultores familiares do DF, a fim de contribuir com subsídios para elaboração de políticas públicas para a agricultura familiar. Estudamos o caso de quatro agricultores familiares situados no Distrito Federal e Entorno que passaram pelo processo de transição agroecológica e produzem de acordo com princípios agroecológicos. Assim, os objetivos específicos são: i) caracterizar os agricultores familiares do estudo; ii) analisar as dimensões da agroecologia pela ótica dos dados obtidos nas entrevistas; iii) identificar de que forma as dimensões da agroecologia consideradas nesse trabalho são operacionalizadas nos sistemas de produção dos agricultores familiares.

Este trabalho está dividido em três capítulos. Em relação à parte teórica, o primeiro capítulo traça o conceito de agricultura familiar e o panorama da agricultura familiar no Distrito Federal, ao passo que o segundo capítulo apresenta a conceituação de agroecologia, aprofundando um pouco mais as categorias de análise referentes às dimensões da agroecologia. No terceiro capítulo apresentamos a caracterização das propriedades dos agricultores familiares e a discussão dos dados obtidos a partir das 
entrevistas e visitas de campo. Por fim, apresentamos as considerações finais à dissertação. 


\section{CAPÍTULO I - AGRICULTURA FAMILIAR NO CONTEXTO BRASILEIRO}

"El estudio de la agricultura ha sido siempre de particular interés para la humanidad. Desde las comunidades humanas, que hace 10.000 años establecieron los primeros cultivos e iniciaron asentamientos permanentes, hasta el siglo XXI, en que la globalización es cada vez mayor, entender el funcionamiento de los sistemas agrícolas ha sido un objetivo prioritario para nuestras sociedades". Gliessman et al. (2007).

\subsection{BREVES CONSIDERAÇÕES HISTÓRICAS SOBRE O DESENVOLVIMENTO DA AGRICULTURA NO BRASIL}

Os países capitalistas desenvolvidos, que atualmente possuem os melhores indicadores de desenvolvimento humano, desde o Estados Unidos até o Japão, apresentam um aspecto em comum: uma agricultura familiar desenvolvida que teve um papel essencial nessas economias na garantia de uma transição equilibrada de uma economia de base rural para uma economia urbana industrial, tendo contribuído para a estruturação de uma economia dinâmica e de uma sociedade equitativa. Ao compararmos esse histórico da agricultura familiar nos países em desenvolvimento percebemos um certo contraste, pois houve diversos desequilíbrios socioeconômicos que foram associados às estratégias de modernização e industrialização adotadas nesses países (GUANZIROLI et al., 2001).

Essas estratégias de modernização agrícola trouxeram consequências ao desenvolvimento rural de países em desenvolvimento, como destacam Guanziroli et al. (2001, p. 15):

\footnotetext{
Estas estratégias basearam-se no estímulo à modernização da grande propriedade tradicional, por meio, sobretudo, de generosos subsídios, o que provocou a redução prematura da demanda relativa por mão-de-obra agrícola, além de inflacionar os preços da terra que acirraram os conflitos fundiários e a consequente expulsão de pequenos produtores na fronteira agrícola. Além disso, o próprio segmento de produtores rurais familiares subsistindo dentro e nas franjas do latifúndio foi duramente atingido pelas políticas de modernização de viés industrial e pela ausência e/ou insuficiência de políticas voltadas para apoiar, consolidar e expandir a produção familiar, em particular programas de reforma agrária, crédito, pesquisa e assistência técnica.
}

Duas razões principais explicam a escolha por esse tipo de estratégia de modernização agrícola. A primeira refere-se à necessidade de manter a concentração de terras nas mãos das oligarquias ainda vigentes (década de 60), enquanto que a segunda 
apoiou teoricamente a primeira razão ao passo que desenhava o papel da agricultura como pouco expressivo na estimulação do crescimento e do desenvolvimento econômico. Ao setor agrícola só bastava financiar a industrialização, assim como fornecer mão-de-obra barata e gerar lucros por meio da agroexportação (GUANZIROLI et al., 2001). Contudo, afirmam os mesmos autores:

\begin{abstract}
Em nenhum momento levou-se em consideração as consequências socioeconômicas e políticas da adoção desta estratégia, em particular sobre a distribuição de renda, tal era a confiança na leitura teórica que colocava todas as expectativas na indústria como dínamo do crescimento, e nas cidades como locus de desenvolvimento. [...] A estratégia adotada era justificada pela necessidade de "modernizar" o campo, de superar as estruturas arcaicas e as limitações associadas à vida rural e aos camponeses, mediante o estímulo à penetração e difusão de empresas agrícolas capitalistas (GUANZIROLI et al., 2001, p. 16).
\end{abstract}

Ainda sobre a estratégia de modernização da agricultura Flores e Macêdo (2000, p. 57) observam:

\begin{abstract}
A estratégia de modernização da agricultura para a produção de grãos para fins de exportação baseou-se no emprego dos chamados pacotes tecnológicos, ao invés de se fundamentar em tecnologias adequadas às necessidades dos agricultores familiares, e como consequência não desencadeou a esperada mudança social.
\end{abstract}

No Brasil a discussão sobre a agricultura misturava-se com a questão agrária principalmente na década de 60 quando se falava sobre os rumos que seguiria a industrialização do país. Contudo, entre 1967 e 1973, o Brasil viveu um período conhecido como o "milagre brasileiro" e nesse período a questão agrária foi pouco foi discutida, tanto por causa da repressão política quanto por causa do entendimento da época que a questão agrícola era sinônima do aumento da produtividade agrícola ocorrida no mesmo período. Poucos reconheciam que o aumento da produção agrícola apenas beneficiava produtos de exportação (café, soja, etc) no lugar de produtos alimentícios (arroz, feijão) e alguns diziam que era uma situação passageira e que logo se normalizaria, o que não ocorreu nas décadas seguintes (GRAZIANO DA SILVA, 1994). Sobre a expansão da agricultura capitalista nas décadas de 60 e 70, Graziano da Silva (1994, p.12) destaca:

E essa expansão destruiu outros milhares de pequenas unidades de produção, onde o trabalhador rural obtinha não apenas parte da sua própria alimentação, como também alguns produtos que vendia nas cidades. Foi essa mesma expansão que transformou o colono em bóia-fria, que agravou os conflitos entre grileiros e posseiros, fazendeiros e índios, e que concentrou ainda mais a propriedade da terra. 
Essa questão de divisão de terras no Brasil vem desde a colonização quando houve grandes porções de terras doadas a particulares, as chamadas sesmarias e dessa forma surgiu a necessidade de exportação em grande escala e como havia escassez de mão de obra incentivou-se a manutenção do já existente tráfico de escravos da época (GRAZIANO DA SILVA, 1994).

\subsection{CONCEITUANDO A AGRICULTURA FAMILIAR NO BRASIL}

A agricultura familiar vem de um longínquo processo histórico, pois era praticada desde o Brasil Colônia. Naquela época as grandes extensões de terra foram doadas a alguns poucos senhores e as pequenas propriedades ficaram relegadas ao interior de grandes fazendas ou áreas de menor interesse econômico. Assim, os primeiros agricultores familiares eram índios, negros e europeus não pertencentes ao grupo de favorecidos pela Coroa. Esses agricultores praticavam uma agricultura de subsistência para a comunidade local, indo de encontro ao modelo agrário exportador. Desse modo, nossa herança de diversas formas de organização da produção da agricultura familiar vem principalmente das culturas negra e indígena (BRASIL, 2002).

No Brasil, o processo de industrialização e urbanização somente começou a ocorrer no século XX, pelos idos dos anos 1930, diferentemente da Europa, que passou por esses processos no século XIX. Nessa época, o governo brasileiro incentivou o processo de implantação de indústrias, assim como as migrações de pequenos agricultores do Sudeste para o Centro-Oeste facilitando a compra de terras a preços mais baixos. Algumas décadas mais tarde, entre 1960 e 1970, o modelo agrícola da Revolução Verde aparece associando mecanização e insumos químicos com o aumento de produtividade. Não podemos negar o aumento de produtividade, porém houve a piora da qualidade dos alimentos e do meio ambiente. O maior símbolo da Revolução Verde no Brasil foi a incorporação da monocultura da soja, principal produto do modelo agroexportador no Cerrado e no Centro-Oeste. Contudo, o pacote tecnológico oferecido pela Revolução Verde era caro e causava dependência da indústria multinacional, assim os agricultores familiares não conseguiram aderir e muitos abandonaram o campo (BRASIL, 2002).

Houve um processo de diferenciação da agricultura brasileira na década de 60 em três regiões do país, segundo Graziano da Silva (1994, p.37): 
a) O Centro-Sul, onde a agricultura se moderniza rapidamente pela incorporação de insumos industriais (fertilizantes e defensivos químicos, máquinas e equipamentos agrícolas, etc.);

b) O Nordeste, que após a incorporação da fronteira do Maranhão (em meados dos anos sessenta) e, mais recentemente, a da Bahia, permanece sem grandes transformações fundamentais no conjunto de sua agropecuária;

c) O Amazônia, incluindo aí boa parte da região Centro-Oeste (Mato Grosso e Goiás), que representou a zona de expansão da fronteira agrícola a partir do início dos anos sessenta.

A agricultura familiar no Brasil é diversificada, pois ao mesmo tempo em que inclui famílias que vivem e produzem em minifúndios ${ }^{3}$ em condições de extrema pobreza, também inclui agricultores inseridos na produção do agronegócio com renda muito superior à renda que define a linha da pobreza. Por exemplo, um agricultor familiar que produz em um minifúndio no sertão nordestino não pode ser comparado com um agricultor familiar integrado às grandes agroindústrias brasileiras. É necessário reconhecer a diferenciação entre os agricultores familiares para a reflexão do desenvolvimento da agricultura familiar e da potencialidade da agricultura alternativa como estratégia de desenvolvimento (BUAINAIN; SOUZA FILHO, 2006). Em relação a essa heterogeneidade observada entre os agricultores familiares, Buainain e Souza Filho (2006, p. 15) consideram:

A diferenciação dos agricultores familiares está associada à própria formação dos grupos ao longo da história, a heranças culturais variadas, à experiência profissional e de vida particulares, ao acesso e à disponibilidade diferenciada de um conjunto de fatores, entre os quais os recursos naturais, o capital humano, o capital social e assim por diante. A diferenciação também está associada à inserção dos grupos em paisagens agrárias muito diferentes umas das outras, ao acesso diferenciado aos mercados e à inserção socioeconômica dos produtores, que resultam tanto das condições particulares dos vários grupos como de oportunidades criadas pelo movimento da economia como um todo, pelas políticas públicas etc. As diferenças são tantas que talvez seja um equívoco conceitual seguir tratando grupos com características e inserção socioeconômicas tão distintas sob o mesmo label — agricultores familiares — apenas porque têm um traço comum: utilizar majoritariamente mão-deobra familiar.

$\mathrm{Na}$ literatura sobre agricultura familiar há o dilema sobre a justificativa e a existência desses agricultores. Como destacam Buainain e Souza Filho (2006, p. 18):

Na chamada visão romântica, os agricultores familiares o são por tradição e opção, não por imposição. A hipótese de que não buscam a maximização do lucro e sim um conjunto de outros objetivos que incluem desde a preservação do patrimônio para as gerações futuras até a geração de ocupação para os membros da família é tomada como paradigma de uma racionalidade

\footnotetext{
${ }^{3}$ Minifúndio é uma área inferior a dimensão da pequena propriedade, ou seja, menor que 01 módulo fiscal.
} 
econômica própria, não como o resultado de restrições reais enfrentadas no passado e no presente.

Entretanto, esses mesmos autores reconhecem que por vezes a agricultura familiar é conceituada de forma errônea e estereotipada, como observam "um setor atrasado do ponto de vista econômico, tecnológico e social, voltado fundamentalmente para a produção de produtos alimentares básicos e com uma lógica de produção de subsistência" (BUAINAIN e SOUZA FILHO, 2006, p. 21).

A agricultura familiar está espalhada por todo o território nacional, com menos incidência na região Centro-oeste e na região Norte. Nas demais regiões a presença da agricultura familiar é maior que $60 \%$, chegando a $80 \%$ nas regiões Sul e Nordeste (BUAINAIN; SOUZA FILHO, 2006). Podemos observar a incidência da agricultura familiar nos estabelecimentos rurais do país, como mostra a Figura 1.

Figura 1. Municípios brasileiros por percentual de estabelecimentos com agricultura familiar.

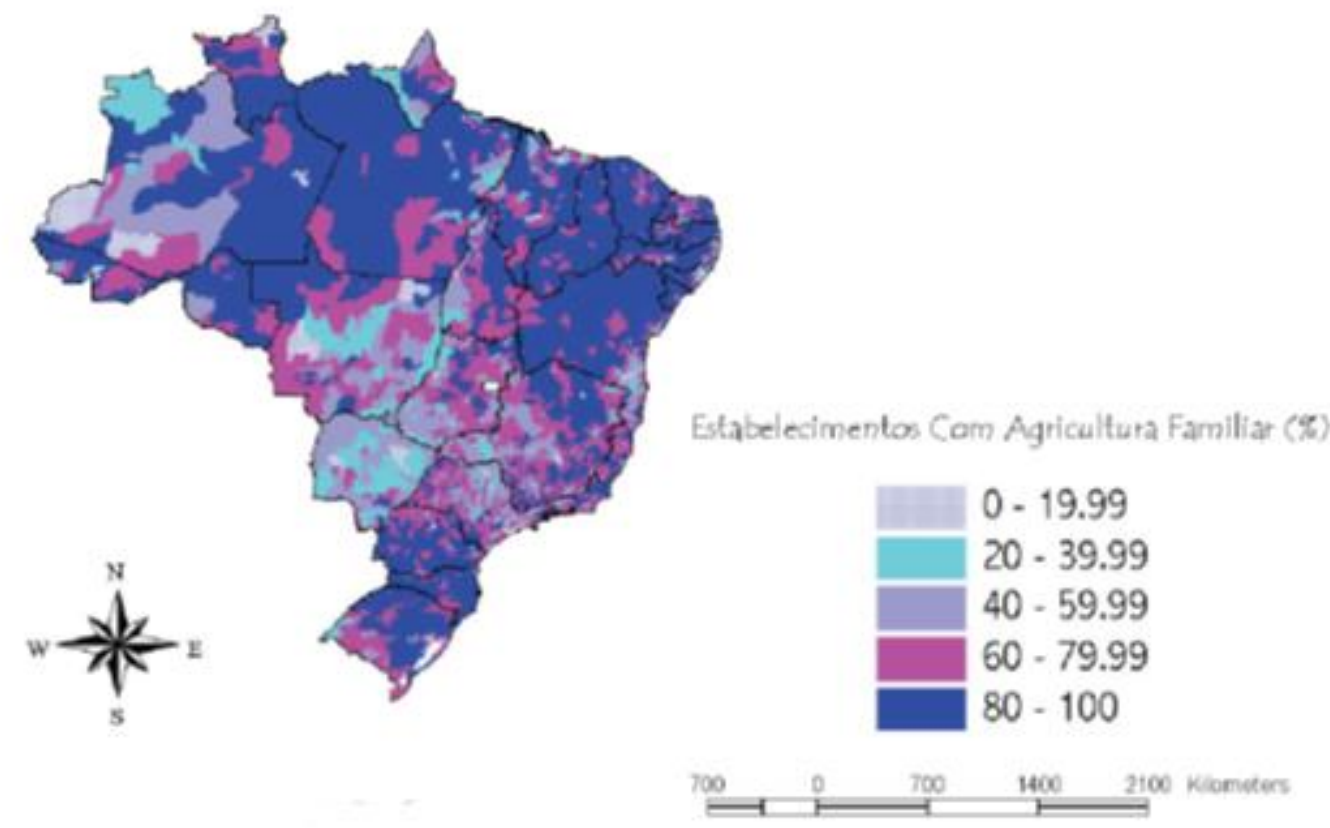

Fonte: Novo Retrato da Agricultura Familiar - FAO/INCRA (apud Buainain e Souza Filho, 2006, p. 24).

O conceito de agricultura familiar é polêmico na literatura sobre o assunto, contudo o denominador comum a todos os conceitos de agricultura familiar é a utilização de mão-de-obra familiar. É necessário que a definição ou o conceito de 
agricultura familiar vá além de simplificações ou uma afirmação absoluta sobre quem pode ser encaixado nessa categoria. É um tanto diversa a produção, os costumes e o contexto em que se encontram os agricultores familiares das regiões do Brasil, como afirma Schneider (2006, p. 09):

[...] o estudo da agricultura familiar requer uma análise sociológica multidimensional sobre a diversidade das formas sociais familiares, que pode começar pelo estudo da organização do trabalho e da produção e sua relação com a natureza, mas passa pelo entendimento dos mecanismos de construção das estratégias de interação com o ambiente social e econômico e reclama a compreensão dos aspectos culturais e simbólicos que caracterizam as suas relações domésticas (parentesco, gênero etc.) assim como os múltiplos meios de exercício da ação política.

$\mathrm{Na}$ agricultura familiar, encontramos novas configurações de vida social que demonstram a inversão da lógica de interpretação de que aquele era um espaço de atraso e exclusão. O local onde a agricultura familiar está inserida é um espaço que possibilita diversidade produtiva e interação com o meio ambiente, de forma que oferece uma condição de bem-estar e qualidade, assim as famílias não precisam sair do campo para a cidade para consegui-las (SANTOS; ARAÚJO; MAIA, 2012). Assim, a agricultura familiar reforça a função social da propriedade rural e é a forma de produção que melhor se ajusta às condições ambientais e socioeconômicas de uma região, conforme destaca Codeplan (2015, p. 48):

\footnotetext{
Os censos agropecuários de diferentes períodos, 1995/96 e 2006 [...] destacam a agricultura familiar como a modalidade de produção melhor ajustada às exigências socioambientais e econômicas de uma região, explicada pelas formas mais equilibradas de distribuição e aproveitamento dos recursos naturais (terra, água, flora e fauna etc.). É a que mais se harmoniza à função social da propriedade rural, principio balizador do aproveitamento racional das riquezas naturais de um país, com equidade e justiça.
}

Em se tratando de diversidade, pluriatividade é um termo utilizado na literatura para explicar o processo de diversificação do trabalho que acontece dentro das propriedades dos agricultores familiares. Ela se dá quando as famílias possuem outras atividades, além da agrícola, ou seja, atividades não-agrícolas, que auxiliam na renda familiar. A pluriatividade tende a ser mais intensa quando as relações entre os agricultores e o ambiente social e econômico em que estão inseridos forem mais complexos e diversificados (SCHNEIDER et al., 2006). Contudo, nem sempre as atividades não-agrícolas exercidas por agricultores familiares são consideradas dentro do conceito da pluriatividade, conforme destacam Schneider et al. (2006, p. 141): 
[...] a pluriatividade refere-se a um fenômeno que se caracteriza pela combinação das múltiplas inserções ocupacionais das pessoas que pertencem a uma mesma família. Portanto, ainda que a pluriatividade seja tributária da combinação de atividades agrícolas e não-agrícolas, não se deve confundir as atividades não-agrícolas com a pluriatividade, pois esta decorre das decisões e das estratégias dos indivíduos e das famílias rurais que podem, ou não, optar pela combinação de mais de um tipo de trabalho.

Não se pode esquecer que os indivíduos que formam uma determinada família podem optar entre combinar duas ocupações (assumindo a condição de pluriativos) ou escolher pela troca de ocupação, deixando o trabalho agrícola e passando a ocuparem-se exclusivamente com atividades nãoagrícolas, mesmo sem deixar de residir no meio rural.

E os mesmos autores, Schneider et al. (2006, p. 138) complementam sobre a função da agricultura, além da produção agrícola:

[...] a pluriatividade serve, ainda, para mostrar a transição da própria função da agricultura que, além de produzir alimentos e gerar emprego, favorecendo o processo de acumulação de capital, se apresenta hoje como um setor multifuncional, que não deve ser analisado apenas pela sua eficiência produtiva, mas também pela sua contribuição à preservação ambiental e à própria dinamização do espaço rural.

A pluriatividade começou a ser reconhecida dentro do contexto de estudos de fenômenos socioeconômicos associados a dinâmicas do meio rural denominadas como "novo rural" ou "ruralidade contemporânea". Esses fenômenos se dividem principalmente entre o aumento das atividades não-agrícolas junto a novas identidades sociais no meio rural e a crise de reprodução da agricultura familiar (CARNEIRO, 2006).

Assim temos que a agricultura familiar é heterogênea, podendo ser pluriativa ou não, em todas as regiões do Brasil devido as especificidades de clima, tipo de colonização e outras variáveis sociais, ambientais e econômicas. Nesse trabalho estudaremos a agricultura familiar no Distrito Federal.

\subsection{AGRICULTURA FAMILIAR NO DISTRITO FEDERAL}

O Centro-Oeste é composto pelos estados de Goiás, Mato Grosso, Mato Grosso do Sul e Distrito Federal, todos em região de Cerrado. Essa região era originalmente ocupada por diversos povos indígenas e somente no século XVIII, após a colonização, vieram os mineradores. Os colonizadores vieram em busca de minérios e, além deles, chegaram também escravos e índios que acompanhavam os pecuaristas, que por sua vez abasteciam a população dos centros mineradores. Assim formou-se uma sociedade 
sertaneja, de fazendeiros pecuaristas, vaqueiros e agricultores até a metade do século XX. Na segunda metade do século o governo incentivou políticas de ocupação dessas áreas pela agricultura modernizada (voltada para o mercado de grãos) e para a construção da nova capital do país (BRASIL, 2002).

Em relação às outras regiões do Brasil, a agricultura familiar no Centro-Oeste se mostra pouco expressiva. O Censo agropecuário 1995/1996 registrou 4.859.732 estabelecimentos rurais no país, desses, mais de 1/3 foram classificados como familiares e a menor classificação foi a da região Centro-Oeste com $66,8 \%$ de estabelecimentos familiares (BUAINAIN; SOUZA FILHO, 2006). Ainda segundo Buainain e Souza Filho (2006, p. 27): “[...] o Centro-Oeste contava com apenas $4 \%$ do total de estabelecimentos familiares no Brasil e menos de $13 \%$ da área ocupada pelos agricultores familiares".

No Centro-Oeste temos o Distrito Federal que possui um território de $5.779,999 \mathrm{~km}^{2}$ e uma área rural com 4.213,520 km² (EMATER-DF, 2009). Segundo Diniz et al. (2014, p. 242), “a estrutura agrária do DF é composta por chácaras, localizadas em colônias agrícolas, núcleos rurais e assentamentos de reforma agrária, com área média não ultrapassando 20 hectares (ha). ". Em relação ao espaço rural do DF temos os seguintes dados segundo a Codeplan (2015, p. 52):

155,44 mil ha às culturas em geral (lavouras, hortaliças e silvicultura); 1,36 mil ha às frutíferas; 144,10 mil ha às pastagens; e, o restante, às reservas legais e às áreas de preservação, abrangendo respectivamente 90,44 mil ha e 43,29 mil ha.

O Distrito Federal possui contradições em relação à ocupação e utilização da terra para a produção agropecuária, pois, apesar de se destacar no quantitativo de produção e representação no Produto Interno Bruto (PIB) por municípios, essa colocação é devida principalmente à participação da agricultura empresarial produtora de commodities e não devido à produção da agricultura familiar, que se encontra em um contexto de desigualdade em termos de extensão de terras e renda (CODEPLAN, 2015). Assim, de acordo com o Censo agropecuário de 2006, a agricultura familiar no DF é responsável por $11 \%$ do valor bruto da produção agropecuária. Segundo a Codeplan (2015, p. 25) a produção agropecuária “[...] cresceu 145,36\% no decênio 2000 a 2010, tem-se mantido com baixa participação na constituição do PIB local, que atingiu $R$ \$ 149,90 bilhões, o oitavo do País, em 2010”. Em relação ao papel da agricultura familiar no DF, o documento da Codeplan $(2015$, p.) destaca: 
Em contexto adverso, de incipientes recursos tecnológicos e financeiros etc., e áreas reduzidas, não raro localizadas em regiões marginais - em termos de solos apropriados, recursos hídricos e infraestrutura básica -, a agricultura familiar, definida na Lei $n^{\circ} 11.326 / 2006$, tem compensado, mesmo que parcialmente, os problemas de abastecimento interno, com a diversidade de produtos - principalmente os hortifrutigranjeiros, em que pese representar apenas $11 \%$ do valor bruto da produção no DF.

Dessa forma, na Lei $\mathrm{n}^{\circ}$. 11.326, de 24 de julho de 2006, é considerado agricultor familiar:

Art. $3^{\circ}$ Para os efeitos desta Lei, considera-se agricultor familiar e empreendedor familiar rural aquele que pratica atividades no meio rural, atendendo, simultaneamente, aos seguintes requisitos:

I - não detenha, a qualquer título, área maior do que 4 (quatro) módulos fiscais;

II - utilize predominantemente mão-de-obra da própria família nas atividades econômicas do seu estabelecimento ou empreendimento;

III - tenha percentual mínimo da renda familiar originada de atividades econômicas do seu estabelecimento ou empreendimento, na forma definida pelo Poder Executivo; (Redação dada pela Lei n 12.512, de 2011)

IV - dirija seu estabelecimento ou empreendimento com sua família.

Assim como em outras regiões do país, no DF também existe a contradição entre a agricultura familiar e a agricultura empresarial principalmente no que concerne a questão de ocupação e utilização do território rural, além de aspectos sociais (tamanho da terra) e econômicos (concentração de renda) (CODEPLAN, 2015). Sobre essas questões Codeplan (2015, p. 35) destaca:

Isto foi reforçado com o fato de o Distrito Federal, a partir dos anos 70, despontar como um dos polos irradiadores de desenvolvimento do país, sobretudo em relação à região Centro-Oeste - uma das expressões do agronegócio brasileiro na atualidade, passando o seu território rural, inicialmente reservado à produção de alimentos, a integrar-se ao referido modelo, a ponto de se destacar como produtor de commodities no ranking nacional, o que esclarece, sob essa ótica, a concentração também acentuada da terra, do crédito e de outros serviços de apoio à agricultura empresarial.

E sobre a questão fundiária no Distrito Federal, o texto da Codeplan (2015, p.

39) afirma:

No Distrito Federal a questão fundiária se inclui entre os seus maiores problemas. As irregularidades relativas à concentração excessiva e indevida de suas terras, enquanto bens de natureza pública e/ou privada, utilizados em desacordo com o princípio da função social da propriedade rural, comprometem a democratização de seu acesso e, por consequência, a sustentabilidade econômica e socioambiental almejada para região. 
Além da questão fundiária também há aspectos relacionados à implementação e eficácia de políticas públicas para a agricultura familiar, tanto no DF quanto no país, que necessitam ser melhor estudadas.

\subsubsection{Considerações sobre algumas políticas públicas da agricultura familiar}

O desempenho da agricultura familiar é dependente de diversos fatores internos e externos ao contexto dos agricultores deste segmento, assim Souza Filho e Batalha (2005, p. 09) destacam:

[...] o desempenho da agricultura familiar é determinado por um conjunto grande de variáveis, sejam decorrentes das políticas públicas e da conjuntura macroeconômica, sejam decorrentes de especificidades locais, mesorregionais e regionais.

Adicionalmente, o desenvolvimento da agricultura familiar encontra desafios históricos como o acesso restrito aos fatores de produção como terra e capital, a ausência de políticas agrícolas e agrárias específicas, assim como a falta de legislação apropriada que viabilizem a produção, a agregação de valor e a comercialização dos produtos processados (ORSI, 2002).

Há ainda uma certa dificuldade dos agricultores familiares no acesso à terra e aos recursos de produção importantes, como a água. No Brasil existem basicamente quatro tipos de acesso à terra: a) a propriedade; b) a ocupação de terras livres ou improdutivas; c) os assentamentos mediante a desapropriação de terras improdutivas e d) as várias formas de dependência do proprietário da terra a variar pela região. A história da agricultura familiar nos auxilia a compreender as políticas públicas que o governo implantou de acordo com os interesses de distintos grupos e classes, para organizar as relações do campo em cada período de tempo e região do país (BRASIL, 2002).

A questão agrária e latifundiária vem sendo desenhada desde a época da colonização. Em relação à concentração de terras no Brasil afirmam Buainain et al. (2005, p. 22):

A estrutura agrária é sem dúvida, um dos condicionantes mais fortes do desenvolvimento da agricultura familiar. No plano mais geral, com exceção de umas poucas áreas, os agricultores familiares podem ser caracterizados como ilhas em meio às médias e grandes propriedades. Essa concentração de 
terra e do poder não ensejou um ambiente favorável para o desenvolvimento local e para a agricultura familiar. No plano micro, disponibilidade, localização e qualidade das terras apropriadas pelos agricultores familiares também se colocam como variáveis que condicionam o potencial de desenvolvimento, a organização e as decisões dos produtores.

É possível observar ausência de políticas públicas voltadas à agricultura familiar antes da década de 90. No Brasil, o programa mais amplamente conhecido é o Programa Nacional de Fortalecimento da Agricultura Familiar (Pronaf) que foi lançado em 1996 e ampliado somente em 2004, a partir daí os agricultores tiveram legitimidade para serem sujeitos e beneficiários de políticas públicas importantes (BUAINAIN; SOUZA FILHO, 2006). Sobre o Pronaf destacam Grisa \& Schneider (2014, p. 132):

O Pronaf se constituiu na principal política agrícola para a agricultura familiar (em número de beneficiários, capilaridade nacional e recursos aplicados) e, historicamente, tem contado com um montante crescente de recursos disponibilizados, atingindo no Plano Safra da Agricultura Familiar 2014/2015, o valor de R $\$ 24,1$ bilhões.

Assim, como desdobramento do contexto da agricultura familiar temos, além da criação do Pronaf, que indicou a urgência de políticas para o desenvolvimento rural, a criação do Ministério do Desenvolvimento Agrário (MDA) em 1999, da Secretaria da Agricultura Familiar (SAF) em 2001 e a Lei da Agricultura Familiar em 2006, que a reconheceu como categoria social, a conceituou e serviu como base para as políticas públicas da categoria (GRISA; SCHNEIDER, 2014). Essa estrutura é reconhecida mundialmente, como também destacam Grisa \& Schneider (2014, p.127):

[...] Brasil é destacado por organizações internacionais multilaterais pela estrutura política e institucional que construiu ao longo dos anos para a agricultura familiar, cujos formatos, objetivos e políticas têm sido “exportados" para outros países.

Dessa forma, a agricultura familiar foi reconhecida como categoria social e política pelo Estado brasileiro por volta da década de 90 e com esse reconhecimento iniciaram-se a construção de políticas diferenciadas para esse grupo. De uma forma didática pode-se destacar as políticas públicas voltadas para a agricultura familiar a partir de três gerações principais, a primeira para o fortalecimento do aspecto agrícola e agrário da categoria social, a segunda em políticas assistenciais e a terceira para a construção de mercados que fortaleçam a segurança alimentar e a sustentabilidade ambiental (GRISA; SCHNEIDER, 2014). A terceira geração de políticas públicas voltadas a essa construção de mercado de fortalecimento da segurança alimentar são representadas nesse trabalho pelo Programa de Aquisição de Alimentos (PAA), 
localmente pelo Programa de Aquisição da Produção da Agricultura do Distrito Federal (PAPA-DF) e pelo Política Nacional de Agroecologia e Produção Orgânica (PNAPO).

\section{Programa de Aquisição de Alimentos (PAA)}

O Programa de Aquisição de Alimentos (PAA) é uma política pública que tem como finalidade fortalecer os agricultores familiares, em especial os que produzem em pequenas quantidades por meio de canais de comercialização nos próprios locais de origem. Esse programa foi concebido visando políticas agrícolas e de segurança alimentar com o intuito de fortalecer a política mundial de combate à fome. Dessa forma, o PAA procura distribuir os alimentos oriundos da agricultura familiar para grupos em situação de insegurança alimentar, além de facilitar a comercialização em âmbito local (MATTEI, 2007). O funcionamento do PAA é descrito por Mattei (2007, p.01):

[...] essa política pública se destina à aquisição de produtos fornecidos pelos agricultores familiares, sendo possibilitada a compra sem licitação de produtos da agricultura familiar até um limite máximo por agricultor ao ano, sendo que os preços não podem ultrapassar o valor dos preços praticados nos mercados locais.

A compra dos alimentos é feita por intermédio da Companhia Nacional de Abastecimento (CONAB) e entregue aos grupos em situação de insegurança alimentar, conforme destaca Müller (2007, p. 73):

Por meio da Companhia Nacional de Abastecimento (CONAB) os alimentos são comprados dos agricultores familiares organizados em grupos formais [...] e entregues às instituições, tais como escolas, creches, associações comunitárias, hospitais, etc., ou a populações vulneráveis à insegurança alimentar $[\ldots]$.

Segundo Schmitt e Grisa (2013, p. 234), o PAA possibilita:

(i) o estímulo a redes locais de produção e distribuição de alimentos oriundos da agricultura familiar para populações em insegurança alimentar; (ii) a regulação de preços por meio da compra de produtos específicos destinados à formação de estoques públicos; (iii) a aquisição de alimentos e formação de estoques pelas próprias organizações sociais (associações e cooperativas),

\footnotetext{
${ }^{4}$ O PAA foi instituído pela Lei $\mathrm{n}^{\circ}$. 10.696. de 02/07/2003 regulamentado pelo Decreto $\mathrm{n}^{\mathrm{o}} .4 .772$ de 02/07/2003 e alterado pelo Decreto ${ }^{\circ}$. 5.783 de 15/08/2006.
} 
visando sustentação de preços e agregação de valor; (iv) a compra e doação de leite a famílias em situação de vulnerabilidade social por meio de um circuito público de distribuição; e (v) o abastecimento de hospitais, presídios, restaurantes universitários e outros estabelecimentos públicos com produtos da agricultura familiar.

No que concerne a contribuição dos mercados institucionais para a produção orgânica e agroecológica, assim como para a agricultura familiar, Grisa e Schneider (2014, p.139) destacam:

[...] PAA e $\mathrm{PNAE}^{5}$ têm contribuído para a valorização da produção local/ regional, ecológica/orgânica e têm ressignificado os produtos da agricultura familiar, promovendo novos atributos de qualidade aos mesmos, associados, por exemplo, à justiça social, equidade, artesanalidade, cultura, tradição etc.

\section{Programa de Aquisição da Produção da Agricultura do Distrito Federal (PAPA/DF)}

O Programa de Aquisição da Produção da Agricultura (PAPA/DF) foi criado pela Lei $\mathrm{n}^{\circ} 4.752$ de 07 de fevereiro de 2012 e tem como finalidade segundo o artigo $1^{\circ}$ da referida Lei:

[...] garantir a aquisição direta de produtos agropecuários e extrativistas, in natura ou manufaturados, e de artesanato produzidos por agricultores ou suas organizações sociais rurais e urbanas, por povos e comunidades tradicionais e pelos beneficiários da reforma agrária.

Nessa lei é garantido que os agricultores familiares e demais beneficiários ou organizações que se enquadrarem na Lei Federal no 11.326 de 24/07/2006 (que é a lei que conceitua os agricultores familiares) podem participar do PAPA/DF e também garante que a aquisição de produtos pelo PAPA/DF seja dispensada de licitação devido à Lei Federal 12.512 de 14 de outubro de 2011.

\section{Política Nacional de Agroecologia e Produção Orgânica (PNAPO)}

A Política Nacional de Agroecologia e Produção Orgânica (PNAPO) foi instituída pelo Decreto $\mathrm{n}^{\mathrm{o}}$. 7.794 , de 20 de agosto de 2012. Essa política tem como objetivo:

\footnotetext{
${ }^{5}$ Programa Nacional de Alimentação Escolar (PNAE).
} 
Art. $1^{\circ}[\ldots]$ integrar, articular e adequar políticas, programas e ações indutoras da transição agroecológica e da produção orgânica e de base agroecológica, contribuindo para o desenvolvimento sustentável e a qualidade de vida da população, por meio do uso sustentável dos recursos naturais e da oferta e consumo de alimentos saudáveis.

A PNAPO traz algumas definições para fins de entendimento do decreto, entre elas destaca-se as definições de produção de base agroecológica e transição agroecológica:

Art. 2o Para fins deste Decreto, entende-se por:

$[\ldots]$

III - produção de base agroecológica - aquela que busca otimizar a integração entre capacidade produtiva, uso e conservação da biodiversidade e dos demais recursos naturais, equilíbrio ecológico, eficiência econômica e justiça social, abrangida ou não pelos mecanismos de controle de que trata a Lei $\mathbf{n}^{\mathbf{o}}$ 10.831, de 2003, e sua regulamentação; e

IV - $\quad$ transição agroecológica - processo gradual de mudança de práticas e de manejo de agroecossistemas, tradicionais ou convencionais, por meio da transformação das bases produtivas e sociais douso da terra e dos recursos naturais, que levem a sistemas de agricultura que incorporem princípios e tecnologias de base ecológica.

Baruja, Dellai e Brandão (2014, p. 03) destacam:

No âmbito da PNAPO, podemos destacar dois órgãos que atuam de forma direta na gestão dessa política. O primeiro é a Câmara Interministerial de Agroecologia e Produção Orgânica- CIAPO, que tem como tarefa elaborar o Plano Nacional de Agroecologia e Produção Orgânica - PLANAPO. E a Comissão Nacional de Agroecologia e Produção Orgânica - CNAPO, que tem a missão de promover a participação da sociedade na elaboração do PLANAPO, propondo as diretrizes, objetivos e as ações prioritárias a ser desenvolvidas.

Ainda segundo Baruja, Dellai e Brandão (2014, p. 04) “Com o lançamento do PNAPO [...] o Brasil passa a ser o primeiro país a criar uma política de Estado específica para o incentivo a agroecologia e a produção orgânica [...]”.

O Plano Nacional de Agroecologia e Produção Orgânica (PLANAPO) é um instrumento de operacionalização da PNAPO, como está explícito no decreto (7.794 de 20/08/2012) que regulamento a Política, no art. $4^{\circ}$, inciso I. 


\section{CAPÍTULO II - AGROECOLOGIA: A ECOLOGIA DOS SISTEMAS AGRÍCOLAS}

"A agroecologia é uma ciência dialética. Como tal, não tem dogmas nem receitas, porém tem princípios. É o caminho mais racional para a produção de alimentos limpos". Machado e Machado Filho (2014).

\subsection{CONCEITUANDO AGROECOLOGIA}

É visível o esgotamento da agricultura convencional ou moderna, assim um dos caminhos viáveis para o desenvolvimento rural sustentável do planeta pode ser pela via da agricultura de base agroecológica. Assim destaca Oliveira, Wehrmann e Sauer (2015, p.66):

Quanto à adoção de práticas mais sustentáveis é fato que o atual modelo de produção agrícola vem mostrando sinais de esgotamento devido aos diversos problemas a ele relacionados, tais como: uso inadequado dos recursos naturais, contaminação do solo e dos recursos hídricos, perda da biodiversidade pela expansão das monoculturas, contaminação dos alimentos por uso excessivo dos agrotóxicos, entre outros. Nesse contexto surgem diversas alternativas que devem ser experimentadas na busca por um modelo de desenvolvimento rural, que seja includente, sustentado e sustentável, contemplando assim as diversas dimensões da sustentabilidade; um exemplo é a agricultura de base agroecológica.

Não é recente a busca do homem por uma agricultura menos agressiva ao meio ambiente, que proteja os recursos naturais e que perdure no tempo, fugindo do modelo convencional de agricultura que foi imposto no início do século XX. Assim, em diversos países começaram a surgir propostas alternativas de agriculturas, com variadas denominações como: natural, biológica, ecológica, orgânica, biodinâmica e permacultura, dentre outras. O quadro 01, elaborado por Caporal (1998), pontua os principais autores e princípios das agriculturas alternativas:

Quadro 01. Agriculturas Alternativas

\begin{tabular}{|c|c|c|}
\hline & Principais protagonistas e & Princípios básicos e alcance \\
seguidores & \\
\hline Agricultura Orgânica & Albert Howard: desenvolve & Princípios: uso de composto, \\
& pesquisas na Índia (anos 1920); & plantas de raízes profundas, \\
& publica An agricultural & atuão de micorrizas na saúde \\
& destament na Inglaterra (1940). & dos cultivos. Difundida em \\
& Técnicas aprimoradas po L.E. & vários continentes. O IFOAM - \\
& Balfour (Método Howard- & International Federation of \\
& Balfour). Introduzida nos EUA & Organic Agriculture Movements \\
\hline
\end{tabular}




\begin{tabular}{|c|c|c|}
\hline & $\begin{array}{l}\text { por J. I. Rodale (anos 1930). } \\
\text { Outros: N. Lampkin (1990). }\end{array}$ & $\begin{array}{l}\text { - atua na harmonização de } \\
\text { normas técnicas, certificação de } \\
\text { produtos e intercâmbio de } \\
\text { informações e experiências. }\end{array}$ \\
\hline Agricultura Biodinâmica & $\begin{array}{l}\text { Rudolf Steiner desenvolve uma } \\
\text { série de conferências para } \\
\text { agricultores na Alemanha (anos } \\
\text { 1920) e estabelece os } \\
\text { fundamentos básicos da } \\
\text { biodinâmica. Pesquisas práticas } \\
\text { realizadas nos EUA, Alemanha } \\
\text { e Suiça (p.e PFEIFFER, 1938; } \\
\text { KOEPF, SHAUMANN; } \\
\text { PETTERSON, 1974). }\end{array}$ & $\begin{array}{l}\text { Princípios: antroposofia (ciência } \\
\text { espiritual), preparados } \\
\text { biodinâmicos, calendário } \\
\text { astrológico; possui marcas } \\
\text { registradas (Demeter y Biodyn). } \\
\text { Muito difundida na Europa. } \\
\text { Presente no Brasil: Instituto } \\
\text { Biodinâmico de } \\
\text { Desenvolvimento Rural, } \\
\text { Estância Demétria e Instituto } \\
\text { Verde Vida. }\end{array}$ \\
\hline Agricultura Natural & $\begin{array}{l}\text { Mokiti Okada: funda a Igreja } \\
\text { Messiânica e estabelece as bases } \\
\text { da agricultura natural; M. } \\
\text { Fukuoka: método semelhante, } \\
\text { porém afastado do caráter } \\
\text { religioso (Japão, anos 1930). As } \\
\text { ideias de Fukuoka se difundiram } \\
\text { na Austrália como } \\
\text { Permacultura, através de B. } \\
\text { Mollison (1978). }\end{array}$ & $\begin{array}{c}\text { Princípios: composto com } \\
\text { vegetais (inoculados com } \\
\text { "microorganismos eficientes"), } \\
\text { valores religiosos e filosófico- } \\
\text { éticos. Movimento organizado } \\
\text { pela MOA-International e } \\
\text { WSAA (EUA). Shiro Miyasaka } \\
\text { dirige a atuação da MOA no } \\
\text { Brasil. }\end{array}$ \\
\hline Agricultura Biológica & $\begin{array}{l}\text { Inicia-se com o método de } \\
\text { Lemaire-Boucher (França, anos } \\
\text { 1960). Grupo dissidente funda a } \\
\text { "Nature et Progrés". Grande } \\
\text { influência do investigador } \\
\text { francês Claude Aubert, que } \\
\text { critica o modelo convencional e } \\
\text { apresenta os fundamentos } \\
\text { básicos de L'agriculture } \\
\text { biologique (1974). }\end{array}$ & $\begin{array}{c}\text { Princípios: a saúde dos cultivos } \\
\text { e alimentos depende da saúde } \\
\text { dos solos; ênfase no manejo de } \\
\text { solos e na rotação de cultivos. } \\
\text { Influenciada pelas ideias de A. } \\
\text { Voisin e pela Teoria da } \\
\text { Trofobiose (Chaboussou, 1980). } \\
\text { Difundida na França, Suiça, } \\
\text { Bélgica e Itália. }\end{array}$ \\
\hline Agricultura Ecológica & $\begin{array}{l}\text { Surge nos EUA (anos 1970), } \\
\text { estimulada pelo movimento } \\
\text { ecológico e influenciada por } \\
\text { trabalhos de Rachel Carson, W. } \\
\text { A. Albrecht, S. B. Hill, E. F. } \\
\text { Schumacher. Na Alemanha } \\
\text { recebeu importante contribuição } \\
\text { teórico-filosófica e prática do } \\
\text { professor H. Vogtmann } \\
\text { (Universidade de Kassel): } \\
\text { Okologicshe Landbau (1992). }\end{array}$ & $\begin{array}{l}\text { Princípios: conceito de } \\
\text { agroecossistema, métodos } \\
\text { ecológicos de análise de } \\
\text { sistemas; tecnologias suaves, } \\
\text { fontes alternativas de energia. } \\
\text { Está difundida em vários países. } \\
\text { Sua introdução no Brasil está } \\
\text { ligada a J. A. Lutzenberger, } \\
\text { L.C. Pinheiro Machado, } \\
\text { A.M.Primavesi, A.D. Paschoal e } \\
\text { S. Pinheiro, dentre outros. }\end{array}$ \\
\hline
\end{tabular}

Fonte: elaborado por Caporal (1998, p.47).

Nesse contexto, surge a Agroecologia, como um novo enfoque científico para dar suporte a uma possível transição para uma agricultura mais sustentável e contribuir para os processos de desenvolvimento rural sustentável. A partir dos princípios da agroecologia foi possível construir agriculturas de base ecológica ou sustentáveis (CAPORAL e COSTABEBER, 2004). Na atual conjuntura, a agroecologia é também 
uma luta política que mostra que é possível viver de outra forma, que é um novo caminho a ser seguido pela humanidade (ARL, 2008).

A agroecologia pode ser vista tanto como enfoque científico quanto como movimento social. Isso porque várias iniciativas de inovação agroecológica ocorreram em diversas regiões do país, antes que o conceito em si tivesse a credibilidade suficiente no âmbito acadêmico, e mesmo assim já demonstrando os benefícios da agroecologia para as populações rurais e para a conservação dos ecossistemas em que elas estão inseridas (MARCO REFERENCIAL EM AGROECOLOGIA - EMBRAPA, 2006).

A agroecologia é, portanto, uma ciência que abarca dimensões sistêmicas diversas e por isso não podemos classificar como agroecologia as agriculturas de base ecológica que, por exemplo, se diferenciam da agricultura convencional apenas por não utilizarem agrotóxicos ou fertilizantes químicos na sua produção. Algumas das razões para essa não utilização de químicos, não exclusivamente, podem ser, como afirmam Caporal e Costabeber (2004, p.9) “(...) corresponder a uma agricultura pobre, desprotegida, cujos agricultores não têm ou não tiveram acesso aos insumos modernos por impossibilidade econômica, por falta de informação ou por ausência de políticas públicas adequadas para este fim".

Ou seja, a partir da existência do conceito de agroecologia ocorre o interesse de alguns em ajustar aspectos da produção agrícola, até na agricultura convencional, para atender aos aspectos sociais, ambientais e de viabilidade econômica. Mesmo assim, é nítido que os ajustes muitas vezes têm foco nos aspectos tecnológicos no que tange a substituição de insumos, porém esse foco não modifica a raiz dos problemas ambientais da agricultura moderna, que vêm da cultura de sistemas em larga escala (ALTIERI, 2004).

É importante considerar a grande diversidade presente no conceito de agroecologia, como descrito no Marco Referencial em Agroecologia (EMBRAPA, 2006, p.21):

Essa diversidade é crucial, pois denota a riqueza que a Agroecologia apresenta quando aplicada às mais diferentes condições territoriais, culturais, socioeconômicas e ecológicas do nosso país. A diversidade ecológica é a base do equilíbrio e da estabilidade dos agroecossistemas e, da mesma forma, a diversidade das ideias e das construções socioculturais é imprescindível para o fortalecimento da Agroecologia.

Assim, os enfoques que delimitam e vinculam o problema da sustentabilidade apenas aos aspectos tecnológicos de produção não conseguem vislumbrar as razões 
principais da não-sustentabilidade dos sistemas agrícolas (ALTIERI, 2004). Seguindo essa linha de raciocínio, Altieri (2004, p.16) afirma que "novos agroecossistemas sustentáveis não podem ser implementados sem uma mudança nos determinantes socioeconômicos que governam o que é produzido, como é produzido e para quem é produzido".

Outro conceito de agroecologia é exposto por Machado (2009, p. 245) quando o autor afirma que "a agroecologia nada mais é do que a agronomia dos anos de 1940 e 1950 do século passado, com a óbvia incorporação dos extraordinários avanços científicos e sociais dos últimos 60 anos".

Assim, a agroecologia é uma abordagem que integra princípios ecológicos, agronômicos e socioeconômicos às tecnologias dos sistemas agrícolas e à sociedade. Além dos aspectos técnicos também incluem as dimensões sociais, ecológicas e culturais (ALTIERI, 2004). É uma ciência e um conjunto de práticas, que envolvem especialmente os seguintes princípios básicos, de acordo com Altieri (2012, p.16): “a reciclagem de nutrientes e energia; a substituição de insumos externos; a melhoria da matéria orgânica e da atividade biológica do solo; a diversificação das espécies de plantas e dos recursos genéticos dos agroecossistemas no tempo e no espaço [...]".

Dentro do conceito de agroecologia podemos encontrar alguns tipos de sistemas diversificados de produção que possuem características variadas, entre esses os sistemas agroflorestais e a agricultura orgânica. Altieri (2004, p.66) define sistemas agroflorestais como "um sistema de uso de terras em que árvores são associadas espacialmente e/ou temporalmente com plantios agrícolas e/ou animais". Já a agricultura orgânica é definida por Altieri (2004, p. 68) como sendo "um sistema que sustenta a produção agrícola evitando ou excluindo em grande parte o uso dos fertilizantes e agrotóxicos sintéticos".

Contudo, conforme destacado pelo grupo de trabalho em agroecologia da Embrapa (EMBRAPA, 2006, p.23):

“(...) as Agriculturas Ecológicas ${ }^{6}$ nem sempre aplicam plenamente os princípios da Agroecologia, já que parte delas está orientada quase que exclusivamente aos nichos de mercado, relegando a um segundo plano as dimensões ecológicas e sociais".

\footnotetext{
${ }^{6}$ As Agriculturas Ecológicas são todas as outras denominadas agriculturas alternativas que não a Agroecologia, entre elas: a Agricultura Natural, a Agricultura Orgânica, a Agricultura Biodinâmica, a Agricultura Biológica, a Permacultura, entre outras.
} 
$\mathrm{Na}$ presente dissertação, os agricultores estudados produzem em sistemas agroflorestais e em sistemas orgânicos.

\subsubsection{Transição Agroecológica}

Em meados dos anos 1950 houve uma transição no mundo, da agricultura tradicional para a agricultura industrial, por meio da Revolução Verde. Agora vivemos um momento que está sendo marcado pela integração entre a agronomia e a ecologia, que está sendo chamado de processo de ecologização (greening process). Esses dois campos estão sendo mais explorados em suas complementaridades para gerar conhecimentos e experiências relevantes, assim como tornar eficientes as intervenções humanas nos agroecossistemas agrícolas (CAPORAL; COSTABEBER, 2007).

Desse modo, esse processo de ecologização pode seguir duas vias diferentes: a corrente ecotecnocrática ou a corrente ecossocial. Enquanto a primeira enfatiza aspectos de intensificação verde como processos produtivos próximos ao padrão dominante, incluindo avanços da biotecnologia, engenharia genética e obedece aos estímulos de mercado, a segunda seria uma corrente que engloba as formas de agriculturas dita alternativas que buscariam maior integração entre os conhecimentos sociais, econômicos, agronômicos, assim com uma base afastada do modelo tradicional, incorporando valores ambientais e de uma nova ética na relação homem-natureza (CAPORAL; COSTABEBER, 2007). Nesse contexto, Caporal e Costabeber (2007, p. 91) destacam o conceito de transição agroecológica:

[...] podemos definir a transição - caracterizada pelo processo de ecologização - como a passagem do modelo produtivista convencional ou de formas de agricultura tradicional à estilos de produção mais complexos sob o ponto de vista da conservação e manejo dos recursos naturais, o que contempla tanto a via da intensificação verde como a via da transição com base na Agroecologia. Não obstante, agregando mais complexidade ao conceito, podemos entender a transição - neste caso, agroecológica - como o "processo social orientado à obtenção de índices mais equilibrados de sustentabilidade, estabilidade, produtividade, equidade e qualidade de vida na atividade agrária", a única via capaz de atender requisitos de natureza econômica e socioambiental, entre outros. 


\subsubsection{Sistemas agrícolas}

Existem diversos sistemas de produção agrícolas, sendo que neste trabalho destacamos os sistemas agroflorestais e os sistemas orgânicos, pois são os sistemas que estão no contexto dos agricultores familiares da presente pesquisa. Segundo o Censo Agropecuário do Instituto Brasileiro de Geografia e Estatística (IBGE) em 2006, quadro 02, destaca-se que o percentual de estabelecimentos que produzem em sistemas agroflorestais representa $5,7 \%$ do total de estabelecimentos da agricultura familiar e a área produtiva corresponde a apenas 3,6\% do total da área.

\section{Quadro 02. Utilização das terras nos estabelecimentos segundo a agricultura familiar}

\begin{tabular}{|c|c|c|c|c|c|c|c|}
\hline \multirow{2}{*}{\multicolumn{2}{|c|}{ Agricultura Familiar }} & \multicolumn{4}{|c|}{ Matas e/ou florestas } & \multicolumn{2}{|c|}{ Sistemas agroflorestais } \\
\hline & & \multicolumn{2}{|c|}{$\begin{array}{c}\text { Matas e/ou florestas } \\
\text { naturais destinadas à } \\
\text { preservação permanente ou } \\
\text { reserva legal }\end{array}$} & \multicolumn{2}{|c|}{$\begin{array}{l}\text { Matas e/ou florestas } \\
\text { naturais (exclusiva área de } \\
\text { preservação permanente e } \\
\text { as áreas em sistemas } \\
\text { agroflorestais) }\end{array}$} & \multicolumn{2}{|c|}{$\begin{array}{l}\text { Área cultivada com espécies } \\
\text { florestais também usada para } \\
\text { lavouras e pastejo de animais }\end{array}$} \\
\hline $\begin{array}{l}\text { Estabele- } \\
\text { cimentos }\end{array}$ & $\begin{array}{l}\text { Área } \\
\text { (ha) }\end{array}$ & $\begin{array}{l}\text { Estabele- } \\
\text { cimentos }\end{array}$ & $\begin{array}{l}\text { Área } \\
\text { (ha) }\end{array}$ & $\begin{array}{l}\text { Estabele- } \\
\text { cimentos }\end{array}$ & $\begin{array}{c}\text { Área } \\
\text { (ha) }\end{array}$ & $\begin{array}{l}\text { Estabele- } \\
\text { cimentos }\end{array}$ & $\begin{array}{l}\text { Área } \\
\text { (ha) }\end{array}$ \\
\hline 4366267 & 80102694 & 794679 & 8120651 & 794358 & 10610156 & 250158 & 2895128 \\
\hline
\end{tabular}

Fonte: IBGE - Censo Agropecuário (2006)

\section{Sistemas agroflorestais (SAFs)}

As tentativas de definir exatamente o conceito de agrofloresta iniciaram-se por volta de 1977 e 1979, e os conceitos geravam em torno da inserção do elemento árvore. Mas alguns autores defendiam que era árvore no sentido de madeira ou para outro uso florestal. Nessa época alguns autores ${ }^{7}$ listavam atributos que eram desejáveis em uma agrofloresta para ser denominada agrofloresta, ou a definiam pelos seus objetivos, aplicabilidade ou função, por exemplo fixação de nitrogênio da atmosfera (no caso de leguminosas), diversidade na produção, aumento de material orgânico (SOMARRIBA, 1992). Ao comparar diversas definições e excluir as incongruências, a primeira aproximação que tiveram do conceito de agrofloresta foi, segundo Somarriba (1992, p. 234):

Agroforestry satisfies five requirements: 1) it is a form of multiple cropping,

2) at least one of the components is a woody perennial, 3) the components are

\footnotetext{
${ }^{7}$ Wiersum, 1981; Agroforestry Systems, 1981; Combe and Budowski, 1979; ICRAF, 1979 e Nair, 1985.
} 
arranged in a defined spatial and temporal order, 4) it involves product diversification, and 5) the components have significant biological and/or economical interactions.

Hoffmann (2013, p. 43) faz uma observação sobre o conceito de sistemas agroflorestais: "O conceito de sistemas agroflorestais não é novo. Novo é o termo para designar um conjunto de práticas e sistemas de uso da terra já tradicionais em regiões tropicais e subtropicais". Candiotto, Carrijo e Oliveira (2008, p. 225) observam que o princípio dos sistemas agroflorestais é baseado na sucessão ecológica que:

[...] consiste no desenvolvimento de estágios sucessivos de recuperação do ambiente florestal, sendo que, em cada fase de recuperação se procura utilizar espécies nativas adequadas para determinada finalidade. Temos, portanto, no manejo agroflorestal, a agrossilvicultura (manejo de árvores com a cultura); os sistemas silvopastoris, que combinam florestas com produção animal; e os sistemas agrossilvopastoris, onde há combinação de agricultura, florestas e produção animal.

Outra definição de agrofloresta vêm do suíço Ernst Götsch ${ }^{8}$, que aproxima o conceito de sistema agroflorestal pela sucessão natural do conceito da "Teoria de Gaia", pela visão holística e de interdependência que ela apresenta ao afirmar que a mudança em uma espécie se refletirá nas outras espécies, assim como Götsch propõe no processo de sucessão natural (PENEIREIRO, 1999). A filosofia é a base do conhecimento sobre sistemas agroflorestais por sucessão natural, Peneireiro (1999, p.75) afirma sobre a teoria criada por Götsch:

\begin{abstract}
Numa abordagem sistêmica, a agricultura, tida como uma prática modificadora dos ecossistemas e voltada para a produção, está inserida num contexto maior e faz parte da dinâmica da vida no planeta, tendo relação inclusive, com o cosmos. Ao elaborar sua teoria para compreensão da vida, que possibilita orientar a definição de ações sustentáveis em relação ao uso dos recursos naturais, Götsch chega a transcender a Teoria de Gaia, como paradigma recorrente, uma vez que ele, além de considerar o Planeta Terra um organismo vivo, onde todas as atividades dos organismos e fenômenos interagem, enxerga o Planeta dentro do contexto cósmico, sendo a vida uma das estratégias de existência do Planeta Terra. Segundo ele, a vida ocorre para que a existência seja possível; a vida é um dos instrumentários do Planeta para assegurar o equilíbrio energético a fim de possibilitar a existência.
\end{abstract}

\footnotetext{
${ }^{8}$ Ernst Götsch é um cientista suíço, nascido em 1948, que estudava melhoramento genético e mais tarde, na década de 70, iniciou estudos sobres sistemas complexos de plantio. Chegou no Brasil em 1982 e atualmente é referência internacional em Sistemas Agroflorestais Sucessionais. Mais informações em: http://agendagotsch.com/about/.
} 
Em sua teoria, Ernst Götsch apresenta fatos interessantes como: a) "tudo no cosmos é inspiração e expiração", assim o sol estaria expirando e a terra inspirando e produzindo matéria orgânica complexa, metabolizando a luz solar em componentes químicos pela fotossíntese; b) "a luz é o único limitante do sistema”, pois a água e os demais nutrientes são disponibilizados pelo planeta quando em equilíbrio; c) "não há casualidade, tudo na natureza funciona de forma sintrópica" (PENEIREIRO, 1999).

Uma definição técnica de sistemas agroflorestais é destacada por Abdo, Valeri e Martins (2009, p.51):

[...] constituem sistemas de uso e ocupação do solo em que plantas lenhosas perenes (árvores, arbustos, palmeiras) são manejadas em associação com plantas herbáceas, culturas agrícolas e/ou forrageiras e/ou em integração com animais, em uma mesma unidade de manejo, de acordo com um arranjo espacial e temporal, com alta diversidade de espécies e interações ecológicas entre estes componentes.

Os sistemas agroflorestais, assim como outros sistemas agrícolas, podem ser classificados em um grau de sustentabilidade menor para o maior dependendo do objetivo e/ou da forma como é plantado. Assim destaca Peneireiro (2003, p.02):

[...] há sistemas agroflorestais elaborados e manejados a partir de diferentes paradigmas também. Há aqueles que se tratam basicamente de consórcios simples, cujo paradigma é o mesmo da monocultura, da competição, e que se preconiza a combinação de algumas espécies para aproveitar melhor os fatores de produção, os insumos e a mão-de-obra, tendo a árvore como componente do sistema, junto com espécies agrícolas; e outros sistemas agroflorestais, como os quintais e outros, mais complexos, que se fundamentam em outro paradigma, buscando os fundamentos na própria floresta, em seus princípios ecológicos, mesmo que, muitas vezes, esse referencial teórico não esteja explícito.

Dessa forma, ao entender que os sistemas agroflorestais podem ser utilizados de diferentes formas e para diferentes necessidades é importante destacar que nesse trabalho foram estudados os sistemas agroflorestais de base agroecológica.

\section{Agricultura Orgânica}

A agricultura orgânica surgiu como um contraponto a produção agrícola convencional que se expandia no mundo e tinha ênfase na importância da matéria orgânica na produção. Foi um método alternativo de produção idealizado por Albert Howars entre 1925 e 1930 na Índia (EHLERS, 1999). Assim é uma técnica/prática agrícola que tem como objetivo produzir sem ou minimizando a quantidade de uso de 
defensivos agrícolas, agrotóxicos e demais contaminantes industriais. Contudo, a agricultura orgânica pode ou não obedecer ao arcabouço teórico da agroecologia, pois os sistemas agrícolas de base agroecológica, segundo Assis e Romeiro (2002, p. 13):

[...] caracterizam-se pela utilização de tecnologias que respeitem a natureza, para, trabalhando com ela, manter ou alterar pouco as condições de equilíbrio entre os organismos participantes no processo de produção, bem como do ambiente.

A agricultura orgânica é muitas vezes conhecida como sinônima de todos os outros tipos de produção agrícola sustentáveis, por vezes até confundida com a agroecologia em si. Por vezes a pressão de mercado e necessidade de constante abastecimento faz com que alguns agricultores de sistemas orgânicos produzam em sistemas monoculturais visando o aumento de produtividade, dessa forma valorizando os aspectos econômicos da produção em detrimento dos aspectos ecológicos, ambientais e sociais, descumprindo assim os princípios agroecológicos (ASSIS; ROMEIRO, 2002).

O objetivo principal da agricultura orgânica é produzir alimentos de uma maneira ecologicamente correta, por meio do abandono do uso de insumos químicos substituindo-os por insumo naturais e tecnologias mais adaptadas aos agroecossistemas, porém nem sempre com preocupação acerca de concentração de riquezas ou questões sociais e culturais. Por outro lado, a agroecologia, além de incorporar o objetivo da agricultura orgânica questiona os aspectos econômicos, sociais e a exploração da força de trabalho dos pequenos agricultores (CANDIOTTO; CARRIJO; OLIVEIRA, 2008).

No Brasil, a produção e comercialização de produtos orgânicos foram aprovadas pela Lei 10.831/03, que dispõe sobre a agricultura orgânica. Contudo a produção orgânica só foi regulamentada a partir do Decreto $n^{\circ}$ 6.323/07 que trata:

Art. $1^{\circ}$ [...] XVII - sistema orgânico de produção agropecuária: todo aquele em que se adotam técnicas específicas, mediante a otimização do uso dos recursos naturais e socioeconômicos disponíveis e o respeito à integridade cultural das comunidades rurais, tendo por objetivo a sustentabilidade econômica e ecológica, a maximização dos benefícios sociais, a minimização da dependência de energia não-renovável, empregando, sempre que possível, métodos culturais, biológicos e mecânicos, em contraposição ao uso de materiais sintéticos, a eliminação do uso de organismos geneticamente modificados e radiações ionizantes, em qualquer fase do processo de produção, processamento, armazenamento, distribuição e comercialização, e a proteção do meio ambiente;

Outras características da agricultura orgânica podem ser observadas no quadro 03 que detalha as diferenças entre a agricultura convencional e a agricultura orgânica. 
Quadro 03. Breve comparativo entre os sistemas de cultivo orgânico e convencional

\begin{tabular}{|c|c|}
\hline Cultivo Convencional & Cultivo Orgânico \\
\hline $\begin{array}{c}\text { - Tecnologia de produtos (aquisição } \\
\text { de insumos) }\end{array}$ & $\begin{array}{l}\text { - Tecnologia de processos (envolve } \\
\text { a relação: planta, solo e ambiente) }\end{array}$ \\
\hline $\begin{array}{c}\text { - Uso de pesticidas } \\
\text { - Fertilizantes químicos-sintéticos } \\
\text { - Baixo de teor de matéria orgânica } \\
\text { no solo } \\
\text { - Monocultura }\end{array}$ & $\begin{array}{c}\text { - Resistência natural e alternativas } \\
\text { - Fertilizantes orgânicos } \\
\text { - Solo rico em matéria orgânica } \\
\text { - Mantém a cobertura do solo } \\
\text { - Rotação de culturas e } \\
\text { biodiversidade }\end{array}$ \\
\hline $\begin{array}{l}\text { - Erosão do solo, empobrecimento } \\
\text { da vida microbiana } \\
\text { - Erradicação dos inimigos naturais } \\
\text { - Desequilíbrio mineral }\end{array}$ & $\begin{array}{c}\text { - Equilíbrio do solo e meio } \\
\text { ambiente } \\
\text { - Aumento do húmus, } \\
\text { microorganismos e insetos } \\
\text { benéficos } \\
\text { - Equilíbrio nutricional }\end{array}$ \\
\hline $\begin{array}{l}\text { - Água e alimentos contaminados } \\
\text { - Contaminação e deterioração do } \\
\text { ecossistema } \\
\text { - Descapitalização }\end{array}$ & $\begin{array}{l}\text { - Água e alimentos sadios } \\
\text { - Ecossistema equilibrado e } \\
\text { saudável } \\
\text { - Sistema auto-sustentável } \\
\text { - Geração de emprego e fixação do } \\
\text { homem no campo }\end{array}$ \\
\hline
\end{tabular}

Fonte: Saquet (2008, p.139)

\subsection{UM OLHAR SOBRE OS MERCADOS AGROECOLÓGICOS E ORGÂNICOS NO DISTRITO FEDERAL}

O recente aumento da oferta de produtos agroecológicos e orgânicos, tanto por agricultores familiares (tradicionais nesse tipo de mercado) quanto por novos entrantes (agricultores capitalizados), além do aumento da demanda da sociedade por esses produtos, estabelece um contexto que vem sendo estudado no intuito de se compreender as relações dos agricultores na construção de mercados e na aproximação com os consumidores. Assim, podemos destacar alguns notáveis trabalhos que vêm sendo desenvolvidos, com substância, na região Sul sobre como as formas de organização coletivas têm reconectado produtores e consumidores (SCARABELOT, 2012; NIEDERLE, ALMEIDA e VEZZANI, 2013).

Há produtos orgânicos oriundos tanto da agroecologia quanto do agronegócio de produtos orgânicos. Pois, o que antes era um nicho de mercado, composto quase que exclusivamente de agricultores familiares de produção orgânica e em sistemas agroflorestais também orgânicos, agora começa a ser composto por produtores 
capitalizados que estão produzindo alimentos orgânicos em escala e nem sempre com o viés social.

Dessa forma, podemos destacar que a aplicação de técnicas na agricultura do agronegócio de produtos orgânicos e da agroecologia é semelhante, porém a diferença abissal consiste na opção de desenvolvimento rural no país. Essa diferença está principalmente no fato de que a agroecologia, desde a suposta fase de transição agroecológica até a fase de amadurecimento social-produtivo se envolve com os aspectos socioculturais dos agricultores enquanto perpassa continuamente a sustentabilidade ambiental. Já o agronegócio de produtos orgânicos procura seguir a mesma lógica de produção, distribuição e comercialização dos produtos convencionais, com produção em larga escala e inevitavelmente distanciando-se da produção agrícola familiar camponesa (COSTA NETO, 2008).

De fato, a relação dos agricultores familiares com os mercados, sejam eles convencionais ou agroecológicos/orgânicos, é complexa e envolve diversos fatores. Essas relações com o mercado não são apenas utilitárias, mas também sociais, e requerem um exercício de conhecimento, habilidade, sociabilidade e poder, pois as pessoas, além das necessidades materiais, também exercem atividades como parte de estratégias e projetos de vida (NAVES, 2008).

A produção nacional de orgânicos apresenta tendência de crescimento nos próximos anos e as atividades de agricultura e pecuária relacionadas à produção orgânica realizadas por pequenos produtores englobam 1,5 milhão de hectares no país. Segundo o Cadastro Nacional de Produtores Orgânicos, disponibilizado pelo Ministério da Agricultura (MAPA), em 2014 havia 7.959 agricultores orgânicos individuais certificados ${ }^{9}$.

Dados de 2013 apontam que os produtos orgânicos são responsáveis por um faturamento de cerca de R \$ 8 milhões por ano no Distrito Federal e, segundo a Empresa de Assistência Técnica e Extensão Rural do DF (Emater -DF), o motivo do aumento do consumo de orgânicos tem ligação direta com o aumento do poder aquisitivo e o relativo barateamento dos custos da produção orgânica ${ }^{10}$. Além das motivações citadas

\footnotetext{
${ }^{9}$ Informações extraídas do site do jornal Correio Braziliense: http://www.correiobraziliense.com.br/app/noticia/economia/2014/04/08/internas_economia,422059/produ cao-organica-mostra-tendencia-de-crescimento-dizem-especialistas.shtml, acesso em 02 mar. 2015.

${ }^{10}$ Informações extraídas do site do jornal Co rreio Braziliense: http://www.correiobraziliense.com.br/app/noticia/cidades/2013/05/25/interna_cidadesdf,367890/cresceconsumo-de-organicos-no-df-faturamento-do-setor-chega-a-r-2-mi.shtml, acesso em 02 mar. 2015.
} 
pela Emater-DF, podemos afirmar que o aumento do consumo de orgânicos também está relacionado à preocupação do consumidor com a saúde, o meio ambiente e o com as relações comerciais mais justas e solidárias. Betti et al. (2013, p.289) afirmam que "o que leva o consumidor às feiras é a qualidade dos produtos, compreendida não apenas em relação ao frescor, sabor e saúde, mas também aos aspectos valorativos que associam esses produtos a novas formas de consumo ético e solidário".

Em relação ao histórico do mercado orgânico no DF, Sabourin et al. (2014) afirmam que a produção orgânica no Distrito Federal surgiu em meados da década de 1980. Logo em seguida, no ano de 1988, um pequeno grupo de agricultores criou a Associação de Agricultura Ecológica (AGE) e no ano de 2002, o Sindicato de Produtores Orgânicos no DF foi criado.

O número de unidades de produção orgânicas, de unidades certificadas, assim como de superfície cultivada e produção de hortaliças vem crescendo conforme a tabela 01. No Distrito Federal pode-se observar três principais tipos de agricultores: a) os agricultores familiares de unidades pequenas, por vezes arrendados ou assentados, b) os agricultores pluriativos, por vezes profissionais liberais e/ou servidores públicos e c) agricultores patronais (empresariais) que possuem vários assalariados permanentes (SABOURIN et al., 2014).

Tabela 01. Evolução da produção orgânica do Distrito Federal

\begin{tabular}{|c|c|c|c|}
\hline & 2006 & 2013 & \multirow{2}{*}{ Aumento (\%) } \\
\cline { 2 - 3 } & $\begin{array}{c}\text { IBGE 2006/ } \\
\text { SEBRAE 2007 }\end{array}$ & EMATER & \\
\hline $\mathrm{n}^{\text {o de unidades de produção }}$ & 161 & 220 & $73 \%$ \\
\hline $\mathrm{n}^{\text {o }}$ de unidades certificadas & 24 & 102 & $425 \%$ \\
\hline Superfície cultivada (ha) & 510 & 775 & $65 \%$ \\
\hline Produção de hortaliças (t) & 3000 & 6900 & $230 \%$ \\
\hline
\end{tabular}

Fonte: Thomas (2013, p.23)

Os agricultores familiares no Distrito Federal têm conseguido aos poucos investir no circuito da venda direta e das feiras agroecológicas por meio de modalidades de coordenação e organização específicas vistas como inovadoras, construídas 
principalmente através de relações de reciprocidade ${ }^{11}$ vinculadas à comercialização (SABOURIN et al., 2014).

\title{
2.3. AS DIMENSÕES DA AGROECOLOGIA
}

Segundo Machado Filho et al. (2010, p.01):

\begin{abstract}
A transição para a Agroecologia é um processo essencialmente mental dos atores envolvidos, que implica em mudanças de paradigmas que envolvem todas as dimensões da Agroecologia (ambiental, energética, econômica, social, política, técnica, administrativa, cultural e ética). Sem convicção, advinda do conhecimento teórico-científico e fortalecida pela prática, não é possível qualquer mudança duradoura e bem sucedida. A Agroecologia é uma ciência multi, inter e transdisciplinar. Multi porquê requer, necessariamente, conhecimentos de diversas disciplinas. Inter porquê é preciso que esses conhecimentos interpenetrem-se dialeticamente entre si e que a abordagem das questões seja holística e sistêmica. Trans porquê é preciso que os atores da Agroecologia consigam relacionar os conhecimentos e conceitos das diversas disciplinas, e esses a uma análise mais global de funcionamento da sociedade e das perspectivas de mudança.
\end{abstract}

O enfoque deste trabalho foi construído à luz da literatura sobre agroecologia, a partir da qual são fornecidas as bases científicas e tecnológicas que permitem a produção de alimentos sem agrotóxicos, além de valorizar as pequenas propriedades rurais. Os sistemas de produção agroecológicos, segundo Altieri (2012, p.15):

\footnotetext{
"são biodiversos, resilientes, eficientes do ponto de vista energético, socialmente justos e constituem os pilares de uma estratégia energética e produtiva fortemente vinculada à noção de soberania alimentar".
}

Dentro do conceito de agroecologia, a sustentabilidade deve ser vista e estudada como a busca entre o equilíbrio das diversas dimensões que podem ser conflitantes na realidade concreta, assim, essa sustentabilidade pode ser definida como a capacidade de manutenção de um agroecossistema de forma socioambientalmente produtiva (CAPORAL e COSTABEBER, 2004). Desse modo, Caporal e Costabeber (2004, p.111) afirmam que "a construção do desenvolvimento rural sustentável, a partir da aplicação dos princípios da Agroecologia, deve assentar-se na busca de contextos de sustentabilidade crescente, alicerçados em algumas dimensões básicas”.

A agroecologia, além dos aspectos técnicos, procura atender às necessidades humanas a partir do viés da sustentabilidade. Assim destacam os autores do Marco referencial em agroecologia - Embrapa (2006, p. 23):

\footnotetext{
${ }^{11}$ Reciprocidade é um conceito da teoria antropológica e da sociologia econômica, trabalhada principalmente por Mauss (2003), Lévi-Strauss (1949) e Polanyi (1957), que supõe uma relação por vezes de troca entre sujeitos, além da troca mercantil ou financeira, uma troca a partir de laços familiares, de status, de ideias.
} 
Ela se concretiza quando, simultaneamente, cumpre com os ditames da sustentabilidade econômica (potencial de renda e trabalho, acesso ao mercado), ecológica (manutenção ou melhoria da qualidade dos recursos naturais e das relações ecológicas de cada ecossistema), social (inclusão das populações mais pobres e segurança alimentar), cultural (respeito às culturas tradicionais), política (organização para a mudança e participação nas decisões) e ética (valores morais transcendentes).

Machado e Machado Filho (2014) destacam as seguintes dimensões: escala, social, política, econômica, ambiental, energética, administrativa, técnica e ética. Nesse sentido já havia escrito Machado (2009, p. 248):

(...) a agroecologia não é apenas uma técnica de produção pois se essa técnica não for acompanhada implicitamente das dimensões social, política, econômica, técnica, administrativa, energética, ambiental e cultural, será uma técnica convencional, sem o componente dinâmico que a dialética incorpora ao processo. Não é suficiente produzir: é necessário produzir respeitando a dialética da natureza com a proteção à biodiversidade e desenvolvendo o processo a partir de e incluindo as dimensões antes citadas.

Para Altieri (2004, p. 17) "para serem eficazes, as estratégias de desenvolvimento devem incorporar não somente dimensões tecnológicas, mas também questões sociais e econômicas". Dessa forma, no presente trabalho, conceituaremos mais detalhadamente as dimensões apresentadas na figura 02, pois são as dimensões que também são destacadas por Caporal e Costabeber (2014) assim as entendemos como básicas para o desenvolvimento rural sustentável por meio da agroecologia. Essas dimensões foram trabalhadas nas entrevistas com os agricultores familiares.

Figura 02. Dimensões da agroecologia abordadas na dissertação
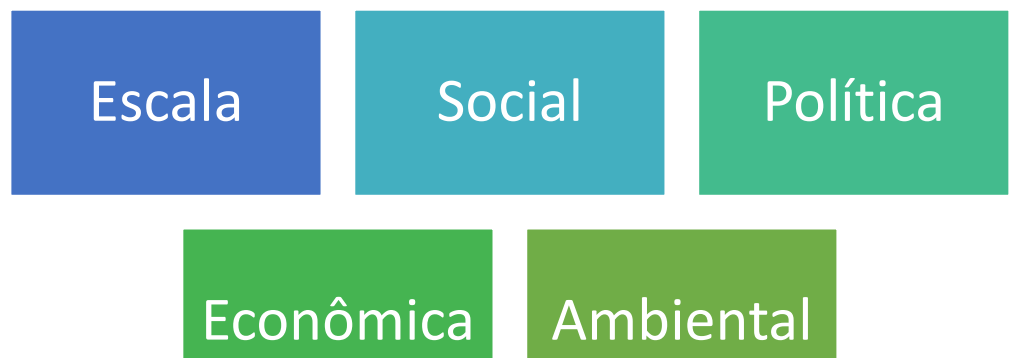

\section{A dimensão ambiental}


“Os procedimentos agroecológicos sempre são definidos a partir da proteção ambiental", afirmam Machado e Machado Filho (2014, p. 194). Enquanto o sistema de produção de monoculturas provoca a contaminação da natureza, o manejo correto do solo, pelas técnicas agroecológicas, permite o aumento de matéria orgânica (MACHADO \& MACHADO FILHO, 2014).

Caporal e Costabeber (2004, p.112) não se referem a uma dimensão ambiental, mas sim a uma dimensão ecológica e, nesse sentido, apontam os seguintes aspectos relacionados a essa dimensão para uma possível elaboração de indicadores:

a) conservação e melhoria das condições físicas, químicas e biológicas do solo; b) utilização e reciclagem de nutrientes; c) incremento da biodiversidade funcional; d) redução do uso de recursos naturais não renováveis; e) proteção dos mananciais e da qualidade da água; f) redução das contaminações por agrotóxicos; g) preservação e recuperação da paisagem natural.

Altieri (2004, p. 21) afirma que "a sustentabilidade não é possível sem a preservação da diversidade cultural que nutre as agriculturas locais”. É necessário que os agricultores utilizem na prática seu conhecimento sobre o solo, a flora e a fauna das terras onde produzem para alcançar eficiência produtiva. Assim, a sustentabilidade será alcançada com o equilíbrio das relações entre o homem, $\mathrm{o}$ ambiente e os agroecossistemas.

A sustentabilidade é um conceito multifacetado e uma dessa facetas é o controle consciente dos processos econômicos e sociais. A questão ambiental não pode mais ser tratada como apenas uma parte do problema e dissociada do processo de produção material (SAUER e BALESTRO, 2009).

Dentro desse contexto de sustentabilidade, equilíbrio de relações entre o homem, o meio e a natureza, Machado (2009, p. 245) discorre:

\begin{abstract}
Ao agro acrescentou-se a ecologia, em razão da indispensável proteção ambiental, diante da destruição desenfreada dos recursos naturais produzidos pelo agronegócio. Ao incorporar-se o sufixo ecologia ao prefixo agro, na verdade, pretendeu-se explicitar as relações dialéticas existentes na natureza, onde tudo depende do todo e, não há fenômeno sem causa e nada acontece isoladamente; qualquer parte está relacionada com todas as partes, é o conceito holístico, onde as partes se relacionam dialeticamente formando o todo, e nenhum fenômeno deve ser analisado se não em função e em relação ao todo.
\end{abstract}

Neste trabalho se considerou relevante averiguar o incremento da biodiversidade nas propriedades dos agricultores familiares, se houve a redução do uso 
de recursos naturais não renováveis e também se houve a preservação e/ou recuperação da paisagem natural.

\section{A dimensão escala}

Essa dimensão refere-se ao volume de produção alcançada, nesse caso específico pelo agricultor familiar orgânico e/ou agroecológico. Refere-se à quantidade de produção, que como dimensão da agroecologia, deve atender (em volume) da mesma forma ou melhor do que o agronegócio atende, ou seja, em escala mundial. É indiscutível que o paradigma do agronegócio pós Revolução Verde é que este alcançou altos rendimentos agrícolas, mas também causou expulsão de pequenos agricultores, aumento da marginalidade e criminalidade, destruição da biodiversidade, concentração de terra e do capital, entre outros fatos (MACHADO e MACHADO FILHO, 2014).

Essa premissa de que a produção deve atender da mesma forma (em volume) do que o agronegócio é defendido por Machado e Machado Filho porque é um benefício que se espera dos sistemas agrícolas agroecológicos, porque para haver uma transição mundial de sistemas em monocultivo para sistemas biodiversos, os agricultores familiares e os agricultores empresariais têm que reconhecer essa possibilidade de que os sistemas agroecológicos têm condição de atender a demanda mundial de produção.

Dessa forma, na dimensão escala foi observada a organização da produção dos agricultores familiares e se eles conseguiam atender às demandas dos mercados onde comercializam. Também observamos se no caso de transição agroecológica houve aumento de produção.

\section{A dimensão social}

A produção de alimentos deve beneficiar a todos que participam a montante e a jusante $^{12}$ do processo produtivo. Dessa forma, deve-se respeitar os valores básicos da cidadania a partir da diminuição da contradição capital-trabalho, assim os agricultores

\footnotetext{
${ }^{12}$ Referem-se a todos os envolvidos no fornecimento de insumos antes da produção em si (montante) e aos envolvidos nos processos pós-produção como logística e comercialização (jusante).
} 
devem fazer parte do processo de forma digna, e não apenas serem um pedaço do elo da cadeia que reforça a concentração de renda (MACHADO e MACHADO FILHO, 2014).

A dimensão social é um dos pilares da sustentabilidade, pois a preservação ambiental e a conservação dos recursos naturais têm real relevância quando os produtos oriundos dos agroecossistemas podem ser igualmente apropriados e usufruídos por toda a sociedade (CAPORAL e COSTABEBER, 2004). Além disso, a dimensão social inclui também segundo Caporal e Costabeber (2007, p.113): “[...] a busca contínua de melhores níveis de qualidade de vida mediante a produção e o consumo de alimentos com qualidade biológica superior”. Ou seja, a produção e consumo de alimentos sem utilização de agrotóxicos.

Caporal e Costabeber (2004, p. 111) destacam os seguintes aspectos indicativos de êxito ou de fracasso das estratégias orientadas pela dimensão Social:

\begin{abstract}
a) produção de subsistência (quali-quantitativa) nas comunidades rurais; b) auto-abastecimento local e regional; c) qualidade de vida da população rural; d) acesso à educação; e) acesso a serviços de saúde e previdência social; f) auto-estima das famílias rurais; g) adesão a formas de ação coletiva baseadas em processos participativos.
\end{abstract}

A partir dos indicativos acima citados, para esse trabalho consideramos relevante estudar o auto-abastecimento local e regional, por meio do desenho dos canais de comercialização dos agricultores familiares.

\title{
A dimensão econômica
}

Tecnologias produtivas devem gerar resultados financeiros para os agricultores que fazem uso delas, mas não devem comprometer as outras dimensões como a social ou a ambiental, por exemplo (MACHADO e MACHADO FILHO, 2014). Mesmo que as tecnologias produtivas sustentáveis, a partir do enfoque agroecológico, consigam um alto volume de produção (escala), elas também não devem causar externalidades ambientais negativas à sociedade. Nesse assunto, destacam Machado e Machado Filho (2014, p. 192): “a não ser em um processo produtivo que não agrida ao solo, que não utilize agrotóxicos nem fertilizantes de síntese química, sem monoculturas e sem concentração, é inviável produzir sem engendrar externalidades ambientais negativas".

É importante salientar que a soberania e a segurança alimentar de um território também se expressam na adoção de estratégias baseadas em circuitos curtos de 
mercadorias e no abastecimento local e regional, deste modo a dimensão econômica é indissociável da dimensão social (CAPORAL e COSTABEBER, 2004).

Em relação aos aspectos que podem ser estudados para a elaboração de indicadores da dimensão econômica, Caporal e Costabeber (2004, p.114) enumeram:

a) melhoria da renda familiar; b) garantia da produção de alimentos; c) estabilidade na produção e produtividade; d) redução das externalidades negativas que implicam em custos para a recuperação do agroecossistema; e) redução nos gastos com energia não renovável e insumos externos; f) ativação da economia local e regional; g) agregação de valor à produção primária; h) presença de estratégias de pluriatividade.

Para essa dimensão o que se investigou neste trabalho foi se a produção orgânica/agroecológica garantia a melhoria da renda familiar; se garantia a produção de alimentos de forma constante; se existia agregação de valor à produção primária e como era feita - se era atividade exclusiva ou não, além de investigar também a presença de estratégias de pluriatividade.

\section{A dimensão política}

A dimensão política da sustentabilidade por meio da agroecologia segundo Caporal e Costabeber (2007, p. 114):

[...] tem a ver com os processos participativos e democráticos que se desenvolvem no contexto da produção agrícola e do desenvolvimento rural, assim como com as redes de organização social e de representações dos diversos segmentos da população rural.

Mesmo ainda estando no modelo econômico capitalista, a agroecologia, sendo mais que apenas uma tecnologia, pode contribuir para uma mudança de paradigma a partir do arcabouço teórico existente, e os exemplos práticos que o comprovem (MACHADO e MACHADO FILHO, 2014). Segundo Caporal e Costabeber (2004, p. 115), a dimensão política:

(...) diz respeito, pois, aos métodos e estratégias participativas capazes de assegurar o resgate da auto-estima e o pleno exercício da cidadania. Entre os aspectos que podem auxiliar no estabelecimento de indicadores de sustentabilidade referentes à dimensão política, mencionamos: a) presença de formas associativas e de ação coletiva; b) ambiente de relações sociais adequado à participação; c) existência de espaços próprios à construção coletiva de alternativas de desenvolvimento; d) marco institucional favorável à intervenção e participação dos atores sociais locais; e) existência de representação local em defesa de seus interesses no âmbito da sociedade maior. 
Em relação à dimensão política, buscou-se responder se os agricultores familiares estão inseridos em alguma representação local que defenda seus direitos, e de que forma essa representação modificou seus processos de trabalho (produção e comercialização). 


\section{CAPÍtUlo III - AS DIMENSÕES dA AGROECOLOGIA PELA PRÁtica DOS AGRICULTORES FAMILIARES}

A agricultura familiar brasileira, como vimos no capítulo I, é heterogênea em todas as regiões do país, e no Distrito Federal principalmente, por possuir características específicas do Centro-Oeste, região tomada pelas grandes plantações do agronegócio (commoditties). O envolvimento de agricultores junto à pesquisa agroecológica é condição para o avanço do conhecimento em agroecologia. Por duas razões, a primeira é pela capacidade de inovação em suas práticas de manejo e a segunda razão é pelos agricultores serem eficientes disseminadores de conhecimentos em seus contextos sociais (MARCO REFERENCIAL EM AGROECOLOGIA - EMBRAPA, 2006).

Assim, os agricultores familiares escolhidos para essa pesquisa foram: Maurício Hoffmann da Fazenda Elo Florestal (Planaltina - DF), Juã Pereira do Sítio Semente (Lago Oeste - DF), Valdir Oliveira do Sítio Vida Verde (Ceilândia - DF) e Wátila José do Assentamento Colônia I (Padre Bernardo - GO/RIDE/DF). Esses agricultores foram selecionados a partir de uma amostragem intencional que levou em conta principalmente os aspectos de localização geográfica, pois todos eles têm suas propriedades no Distrito Federal e, também, pela facilidade de contato e abertura para participar dessa pesquisa. A amostra foi não probabilística pois nos dirigimos a determinados elementos considerados típicos do universo que estudamos (DIEHL \& TATIM, 2004).

Foi realizado um estudo de casos múltiplos, assim consequentemente sendo uma pesquisa qualitativa pois, segundo Flick (2004, p.28): “É orientada para a análise de casos concretos em sua particularidade temporal e local, partindo das expressões e atividades das pessoas em seus contextos locais". A pesquisa de campo foi realizada entre os meses de junho e julho do ano de 2015 e consistiu em visita exploratória às propriedades dos agricultores familiares para a caracterização, histórico e descrição do sistema de produção utilizado. Durante as visitas, também foram realizadas entrevistas semiestruturadas, com perguntas direcionadas às cinco dimensões da agroecologia destacadas por Machado e Machado Filho (2014): escala, social, política, econômica e ambiental. Essas entrevistas foram feitas nas propriedades de cada agricultor, com exceção da entrevista do agricultor Wátila, que foi realizada no ponto de comercialização de orgânicos mantido pela sua associação, com vendas às terças e quintas de manhã na UnB, em frente à ala norte do Instituto Central de Ciências (ICC). 
A duração das entrevistas foi de aproximadamente uma hora e meia, tendo sido utilizados um aplicativo em um tablet para a gravação e um caderno de anotações, além do roteiro com as perguntas dos principais temas das dimensões.

As entrevistas semiestruturadas foram transcritas e a partir da degravação tivemos quatro documentos divididos pelas respostas de cada agricultor respectivamente. A vantagem da entrevista é que esta técnica pode ser utilizada para todos os segmentos da população, há maior flexibilidade entre o entrevistador e o entrevistado, há oportunidade de avaliar condutas, há oportunidade de obter dados que não estejam documentados e por vezes permite que os dados sejam quantificados. A limitação pode estar relacionada à dificuldade de expressão de ambas as partes, incompreensão da pergunta por parte do entrevistado, a disposição do entrevistado em dar as informações (MARCONI \& LAKATOS, 2010). Nesse trabalho algumas perguntas foram respondidas por todos os agricultores de forma completa, como na dimensão ambiental, e outras perguntas não foram respondidas completamente.

Foram categorizadas as informações que queríamos estudar nas próprias dimensões da agroecologia: escala, social, política, econômica e ambiental. Posteriormente esses dados foram tratados qualitativamente por meio do software Sphinx, que permitiu a categorização das respostas de cada agricultor por bloco temático (as cinco dimensões). Dessa forma a utilização do software permitiu uma visualização mais organizada e de maneira mais simplificada do que se as respostas tivessem sido separadas manualmente. Assim, com essas informações destacadas em mãos fizemos a comparação das respostas dos agricultores com as características e informações presentes na literatura sobre as dimensões da agroecologia.

Para uma melhor organização das falas transcritas na discussão foram fixadas as falas do agricultor da Fazenda Elo Florestal como agricultor familiar A, as falas do agricultor do Sítio Vida Verde como agricultor familiar B, as falas do agricultor do Sítio Semente como agricultor familiar $\mathbf{C}$ e as falas do agricultor do Assentamento Colônia I como agricultor familiar D. 


\subsection{CARACTERIZAÇÃO DAS PROPRIEDADES DOS AGRICULTORES}

Mapa 01. Localização das propriedades dos agricultores familiares da pesquisa no DF e Entorno.

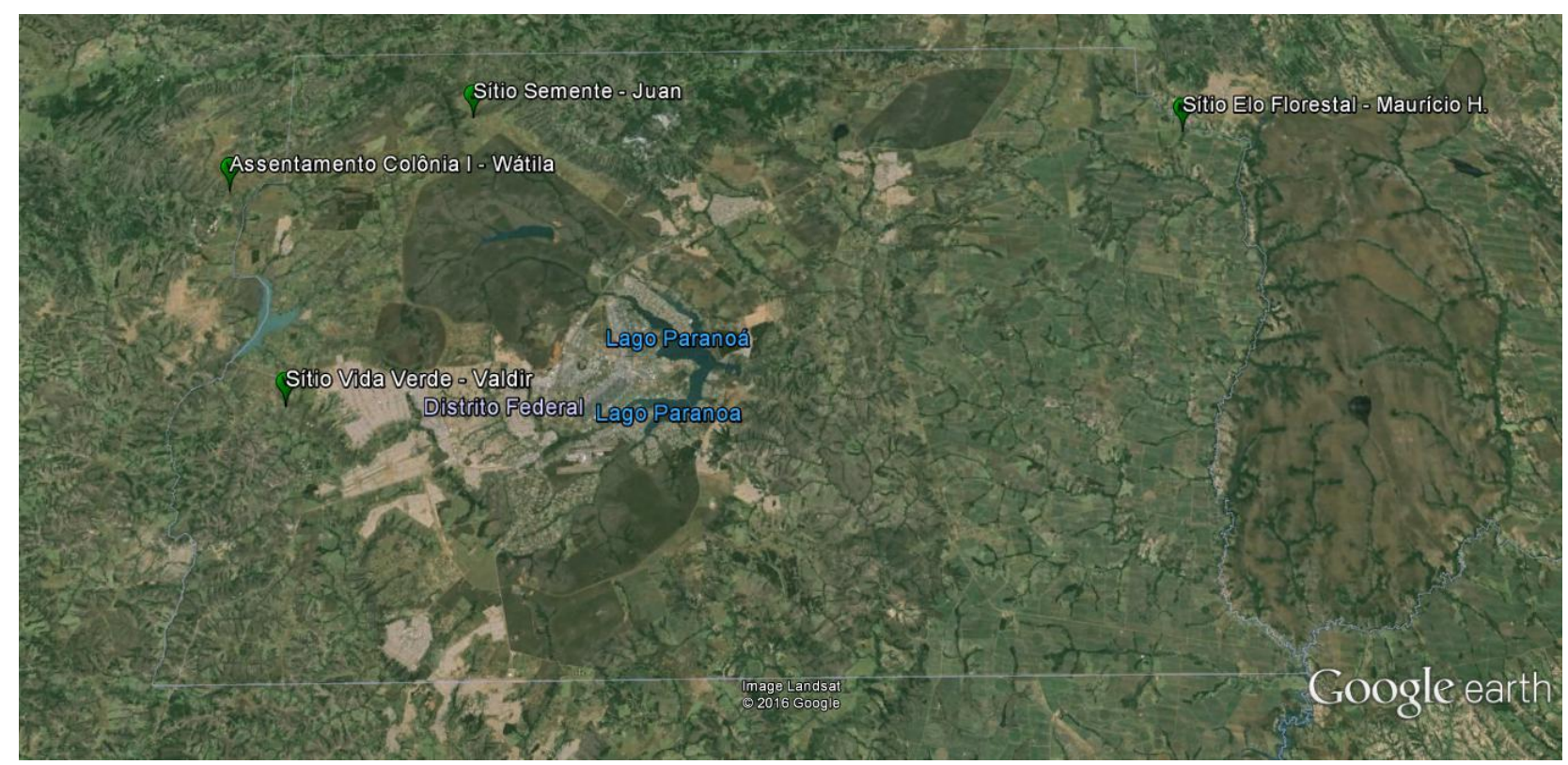

Fonte: Google earth

\subsubsection{Fazenda Elo Florestal}

A Fazenda Elo Florestal está localizada no Núcleo Rural Taquara, área rural de Planaltina-DF e é propriedade da família Hoffmann desde 1985. Nessa época era gerenciada, manejada e cuidada pelos pais do agricultor Maurício Hoffmann. Naquela época até meados de 2001, plantava-se essencialmente monocultura - milho e hortaliças em produção de sistemas de hidroponia em estufas. A partir do ano de 2001, a fazenda passou a ser responsabilidade do Maurício Hoffmann, que trabalha com Sistemas Agroflorestais (SAFs) desde 2003 no Brasil e exterior, tendo sido aprendiz de Ernst Gotsch.

Entre 2001 e 2005, o agricultor trabalhou com o que ele chama de áreas de reflorestamento. Eram áreas experimentais, onde havia mais de dez tipos de sistemas agrícolas, sendo que naquele momento ele estava definindo a tecnologia que colocaria em escala. Tecnologias como as hortas circulares e uma área com plantio de capim elefante, por exemplo. Após esse período de experimentações, a primeira tentativa de comercialização de produtos agroflorestais aconteceu por meio da horticultura em 2006, 
que logo foi abandonada por causa da baixa rentabilidade. Já em 2008, a segunda tentativa foi o bananal em escala e a partir daí mais espécies foram somando-se a essa área.

Antes da propriedade ser da família, em meados da década de 1970, a área em que se encontra a fazenda era Cerradão. Atualmente são 40 hectares de terra utilizadas como área de plantio e 35 hectares de mata de galeria. A área do bananal possui acima de 50 espécies vegetais e em toda a propriedade há em média 25 espécies por hectare. Hoje, o principal negócio da fazenda é a fruticultura, são 1,4 hectares de banana e 1,6 hectares de outras frutas (maracujá, pitaya, mamão, laranja lima, tangerina, laranja bahia e limão tahiti). Todas essas frutas são plantadas em sistemas de consórcio agroflorestal, organizadas em linha de plantio (leiras) e a irrigação é por aspersão alta. Além disso, também comercializam mel agroflorestal (da abelha Apis Mellifera) que é coletado, idealmente, duas vezes ao ano.

Por produzir em Sistemas Agroflorestais, a fazenda possui um viveiro onde são produzidas 250 mudas de árvores frutíferas por mês que são plantadas na própria fazenda. Além disso, conta com o auxílio de um funcionário que trabalha na parte de produção e manejo (o funcionário recebe porcentagem pela produção).

\subsubsection{Sítio Vida Verde}

O Sítio Vida Verde está localizado no Núcleo Rural Boa Esperança, em Ceilândia DF. A propriedade possui uma área de 08 hectares e produz em 4,9 hectares essencialmente hortifruticultura. O escoamento da produção (cerca de doze produtos) é para a Feirinha Orgânica da Estação Biológica (FOEB), para Empório Malunga e para os programas institucionais PAA e PAPA-DF. O sítio Vida Verde é uma das unidades agroecológicas mais antigas do DF que ainda, como outra fonte de renda, realiza palestras sobre sua experiência. O Seu Valdir, que é o agricultor a frente do sítio Vida Verde, até o ano de 2007 produzia de forma convencional, sobre isso ele diz: "minha produção convencional matava eu e o mundo todo". Seu Valdir relata que iniciou o processo de transição agroecológica entre os anos de 2007 e 2008, com o auxílio principalmente da Emater-DF.

É uma propriedade que passou pela experiência da transição agroecológica a partir do momento em que o agricultor do sítio visitou e conheceu uma agrofloresta. Em 
seguida, o sítio conseguiu fazer parte de um projeto $^{13}$ da Emater-DF que implantava unidades de demonstração para agroflorestas e agricultores familiares, iniciando a consciência da mudança, assim gerando segurança alimentar e renda (MORETTO; SALLES DA SILVA, 2014).

\subsubsection{Sítio Semente}

O sítio Semente está localizado no Núcleo Rural Lago Oeste, em SobradinhoDF (mapa 01). Sua produção agrícola é por meio de sistemas agroflorestais e os principais produtos são inhame, banana, mamão, alface, cenoura, jiló, rúcula, café, laranja, mandioca. O escoamento de produtos do sítio é por meio do PAPA-DF, PAA e feiras orgânicas. Além disso, o sítio recebe visitas guiadas à propriedade duas vezes por semana e também oferece um curso prático de manejo de sistemas agroflorestais (SAFs).

O agricultor familiar a frente do sítio Semente é Juã Pereira, 34 anos. Em 2004, ele já tinha o sítio e estava concluindo a faculdade de biologia, quando teve a oportunidade de estagiar na Embrapa na área de agroecologia. Posteriormente ele participou de um curso de SAFs no Instituto Oca Brasil em Alto Paraíso (GO) ministrado por Ernst Gostch. Sobre Ernst ele destaca "O Ernst é a grande inspiração, é o grande criador desse sistema agroflorestal, em todos os aspectos, no Brasil inteiro, no mundo inteiro".

\subsubsection{Assentamento Colônia I}

O Assentamento Colônia I está localizado na cidade de Padre Bernardo - GO, em uma região denominada de Monte Alto, ficando a $15 \mathrm{~km}$ de Brazlândia e $80 \mathrm{~km}$ de Brasília, esse município ocupa uma área de $3138 \mathrm{~km}^{2}$ (JACINTHO, 2007). O Assentamento Colônia I foi implementado em 1996, onde foram assentadas 24 famílias, compostas de pessoas que vieram de realidades distintas e cada família recebeu um lote de 16,5 hectares a 24 hectares (JACINTHO, 2007). A localização do assentamento na figura

A proposta de produzir organicamente veio no ano 2000 a partir de um processo de capacitação oferecido por um projeto de extensão da UnB do Grupo de

13 Projeto "Biodiversidade e transição agroecológica de agricultores familiares" apoiado pelo MCT/CNPQ/MDA/SAF/MDS/SESAN e teve como instituições participantes a Emater-DF, Embrapa Hortaliças, Embrapa Recursos Genéticos e Biotecnologia e UnB. 
trabalho de apoio à Reforma Agrária (GTRA) ${ }^{14}$ no Assentamento Colônia I e, no início dessa organização, o assentamento era formado por 24 famílias, porém apenas 12 interessaram-se pelo processo de trabalho. Wátila Santos, 32 anos, agricultor do ACI entrevistado para esse trabalho, conta que durante o processo de formação algumas famílias desacreditaram no processo e na questão dos orgânicos e atualmente (2015) apenas 04 famílias trabalham com o sistema orgânico de produção.

Palavras do Wátila sobre o início e implementação do Assentamento Colônia I:

Então, em 1996, surgiu o Assentamento, todo mundo foi pro assentamento e teve a expectativa de produzir convencional, fazer produção convencional, só que todo mundo quebrou a cara, né? Porque a gente entrou no cerrado, nas terras improdutivas sem água, sem energia elétrica, sem moradia própria de qualidade, sem qualidade de vida e tentou sobreviver e não conseguiu.

Um dos principais motivos destacados pelo agricultor para essa redução no número de famílias é a questão da falta de água no Assentamento para produzir. Ele informou que havia uma cisterna, um poço furado manualmente que mesmo com trinta ou quarenta metros de profundidade não saía água. Assim, resolveram coletivamente fazer um poço semi-artesiano, apesar do impacto ambiental, por questão de sobrevivência. Ele destaca que alguns assentados aderiram e outros não. Esses que não quiseram não tiveram sucesso.

\subsection{ENTENDIMENTO E IDENTIFICAÇÃO DOS AGRICULTORES FAMILIARES ENTREVISTADOS SOBRE AGRICULTURA ORGÂNICA E AGROECOLÓGICA}

Em um primeiro momento foi abordada a questão da identificação dos agricultores com os conceitos de agricultores orgânicos e agroecológicos. Nas entrevistas eles informavam ser agricultores orgânicos, agroecológicos ou até mesmo os dois. Alguns afirmaram que já produziam em sistemas agroflorestais/sistemas orgânicos antes do termo agroecologia estar difundido no meio acadêmico ou comercial. Por essa razão, alguns afirmaram se considerar agricultores orgânicos pela certificação que possuíam e outros agroecológicos pelas técnicas de produção utilizadas. Dessa maneira, os agricultores A e B identificaram-se como orgânicos e agroecológicos. Eles destacam:

\footnotetext{
${ }^{14} \mathrm{O}$ Grupo de Trabalho de apoio à Reforma Agrária (GTRA) da UnB, enviou um projeto para Petrobrás, com o título "Educando para a Sustentabilidade, horta orgânica e viveiro comunitário e organização social para o Projeto de Assentamento Colônia I". O projeto foi aprovado em 2001, envolvendo 12 famílias que se organizaram e formaram o "Grupo Vida e Preservação" (GVP).
} 
Orgânico porque eu tenho certificação orgânica. Hoje em dia para se dizer que é orgânico tem que ter certificação. Agroecológico porque tem princípios que eu uso que não são exigidos por lei. Sistemas agroflorestais têm uma série de princípios e técnicas que a lei não exige, por exemplo a biodiversidade. (Agricultor A)

Pra mim o princípio é tudo igual. A diferença é que em um (sistema agroecológico) vai árvores, vai espécies altas e o outro é rasteira, hortaliças geralmente é rasteira, são baixas. No meu sistema aqui eu trabalho hortaliça no sentido orgânico acompanhado de agroflorestas. (Agricultor B)

$\mathrm{O}$ agricultor $\mathrm{C}$ denomina-se orgânico com a mesma justificativa do agricultor A, porque tem certificado de orgânico, mas ressalta que (pensa que) é mais do que orgânico pois produz em sistemas agroflorestais. Já o agricultor D considera-se agroecológico e justifica:

Porque a produção agroecológica vai além da produção orgânica. Quem produz na produção agroecológica pensa além da comercialização. [...] Pensa na sustentabilidade, no processo de engajamento da sociedade. [...] Por isso a gente vai além da produção orgânica, se fosse só produção orgânica (era) só produzir, fazer pequenos agronegócios.

Nesse sentido de o agricultor denominar-se orgânico ou agroecológico, a dificuldade de se denominar especificamente como agroecológico talvez resida no fato do termo não estar tão acessível como corrobora Schmitt (2009, p. 181):

A palavra agroecologia não está presente, necessariamente, na teia de relações e significados que serve de referência a muitas dessas experiências, o que não significa que princípios e práticas passíveis de serem identificados como ecológicos ou agroecológicos não estejam integrados às formas de manejo dos sistemas produtivos desenvolvidas pelos camponeses, agricultores familiares modernizados, extrativistas [...].

Em relação à transição agroecológica, o agricultor A defende que a transição é mais benéfica ao agricultor do que a ruptura, no sentido que as mudanças são feitas de forma gradual dentro do próprio sistema de produção e não necessariamente abandonando o que ainda há de convencional na propriedade. Assim, ele afirma:

[...] a ruptura gera uma quebra financeira, o melhor é fazer uma transição. Porque muitas vezes, as propriedades rurais já têm um negócio em andamento, (geralmente) convencional. [...] Como sistemas agroflorestais não são uma tecnologia em si, mas um conjunto de técnicas, todas elas podem ser introduzidas devagarzinho dentro do sistema de produção. Se (o agricultor) trabalha com adubação tradicional passa a usar adubação orgânica, não é uma ruptura com o sistema, (mas) com as indústrias de fornecimento de insumo químicos e agrotóxicos. 
Ao entrevistar os agricultores percebemos que as respostas se mesclavam entre diferentes dimensões (que haviam sido previamente preestabelecidas), justamente porque no cotidiano o agricultor não segmenta seus processos de trabalho por causa dos princípios, pelo contrário, seus princípios são intrínsecos no cotidiano deles. Sobre essa percepção, Schmitt (2009, p. 197) considera:

Os recursos ou ativos utilizados pelos indivíduos e grupos como forma de garantir sua reprodução social não se configuram, simplesmente, como meios materiais, estando imersos em uma teia de significados na qual esses agentes constroem suas identidades e conferem sentido a suas práticas.

As respostas obtidas nas entrevistas variam em termos de complexidade, empirismo e/ou conhecimento formal. Os agricultores A, B e D possuem nível superior, enquanto que o agricultor $\mathrm{C}$ possui nível fundamental incompleto. Assim, observa-se uma heterogeneidade na questão da escolaridade. A seguir temos a descrição e análise das respostas dos agricultores familiares em relação as dimensões da agroecologia que foram propostas.

\subsection{CONSIDERAÇÕES SOBRE AS DIMENSÕES DA AGROECOLOGIA PELOS AGRICULTORES FAMILIARES}

Os dados estão apresentados separadamente em dimensões seguindo a estrutura de blocos temáticos utilizada na entrevista, apenas para ficar mais clara sua apresentação. Essa observação é importante pois as dimensões são holísticas e alguns dados poderiam ser apresentados ou identificados em mais de uma dimensão.

\subsubsection{Dimensão Ambiental}

Todos os agricultores afirmam que a produtividade dos seus sistemas agroflorestais aumentou devido à inserção de novas espécies. O agricultor A afirma que por causa da biodiversidade houve o controle de pragas e a diminuição de custos relativos a esse controle na sua propriedade. $\mathrm{O}$ agricultor $\mathrm{B}$ disse que cada agricultor tem uma realidade de sistemas agroflorestais diferentes, pois a partir das técnicas agroflorestais eles adaptam sua produção da forma que lhes convém. O agricultor D relata que durante a transição agroecológica havia muitos ataques de praga e incidência 
de doenças nas plantas, mas com o tempo o ambiente foi se adaptando às novas técnicas e foi restabelecido o equilíbrio de solo e nutrientes.

Observa-se na experiência dos agricultores acima descritos a materialização da teoria, pois, segundo Altieri (2014, p.19) “quando a biodiversidade é restituída aos agroecossistemas, numerosas e complexas interações passam a estabelecer-se entre o solo, as plantas e os animais". Entre essas interações podemos destacar a contínua cobertura vegetal, a conservação do solo e dos recursos hídricos, proteção contra o vento, intensificação do controle biológico de pragas, além de assegurar uma produção livre de insumos químicos degradantes (ALTIERI, 2014).

Podemos observar na conduta dos agricultores o que na literatura Machado (2009, p. 249) afirma: “A conduta agroecológica não usa qualquer herbicida, independente de sua origem, porque não queremos solucionar problemas; nossa conduta é não ter problemas".

A irrigação por aspersão é o método que todos os agricultores utilizam. Em relação à quantidade de água usada no sistema agroflorestal, o agricultor A afirmou que como o solo está sempre coberto evita-se a perda de água e tem-se menos vento também. Dessa forma as folhas que cobrem o solo diminuem a evaporação, pois mantém a umidade. O agricultor B relembrou que quando produzia no sistema convencional a bomba de água ficava ligada o dia inteiro, já no sistema agroflorestal, ele irriga a cada dois dias. Ele afirma que "agrofloresta não precisa aguar". O agricultor C relata que o sistema agroflorestal dele hoje comparado ao sistema orgânico convencional economiza de quatro a cinco vezes a quantidade de água que é usada para a mesma cultura. Ele diz que enquanto no sistema convencional eles irrigam durante trinta minutos três vezes ao dia, no sistema agroflorestal dele irriga somente quinze minutos por dia, ou seja, uma hora e meia contra quinze minutos ao dia. O agricultor D também citou matéria orgânica como forma de manter a umidade do solo e afirmou que irriga cada área de cultivo durante quinze minutos por dia. O benefício da utilização do sistema agroflorestal também é percebido na literatura por Hoffmann (2013, p.01) que destaca:

[...] as tecnologias agroflorestais são ferramentas potenciais de construção da segurança e soberania alimentar no Brasil, de melhoria do bem-estar da população e conservação dos recursos naturais, possibilitando a ampliação das áreas com conservação ambiental, manutenção da biodiversidade, mantendo a integridade das bacias hidrográficas e a estabilidade do clima. 
Em relação ao maquinário agrícola, todos possuem microtrator (tobata) e roçadeira costal (motoserra). Além desses, o agricultor A possui um moinho para moer matéria orgânica, o agricultor $C$ possui um super triturador para moer matéria orgânica também e o agricultor $\mathrm{D}$ possui um pequeno caminhão e uma grade de terra. Os agricultores são unânimes ao afirmar que a utilização do maquinário agrícola é indispensável por diminuir o desgaste físico, por aumentar a produtividade e por possibilitar a realização de um trabalho em menos tempo do que vários homens levariam para realizar. Destaca-se a utilização unânime de maquinário agrícola por todos os agricultores familiares, assim como afirma Machado e Machado Filho (2014, p. 41): "Certamente a agroecologia utiliza todos os benefícios da ciência, da mecanização e do progresso tecnológico, mas sempre para amplificar a eficiência do trabalho e reduzir o esforço do trabalho humano e não para aumentar o lucro dos fabricantes".

Todas as propriedades visitadas possuíam área de preservação ambiental. Na propriedade do agricultor A há uma Área de Preservação Permanente (APP) e na propriedade do agricultor D há três hectares produtivos e quinze hectares sem produzir que são compostos de Cerrado intacto. A propriedade do agricultor B tem definidas as áreas de APP e reserva legal, sendo que a APP totaliza meio hectare, e a reserva legal possui 03 hectares e está intacta. Ele pretende inserir o sistema de produção na reserva legal, pois é permitido por lei (Código Florestal). Nesse mesmo sentido afirma o agricultor $\mathrm{C}$ :

O Sistema Agroflorestal (SAF) hoje encaixa para recuperar APP, tanto para reserva legal, quanto no sistema de produção. Na hora que eu for fazer o Cadastro Ambiental Rural $(C A R)^{15}$ eu vou pôr a reserva legal dentro do meu sistema de produção. (...) Se você tiver APP tem que preservar, agora reserva legal você tem que decidir onde vai ser. Então quando eu for decidir, o SAF já está incluído. Não vou precisar fazer um cantinho separado para reserva legal, porque a melhor reserva legal é a agrofloresta, produtiva.

A inserção dos SAFs na reserva legal é permitido, assim como destaca Abdo, Valeri e Martins (2009, p.58):

O Código Florestal dá possibilidades de implantação de sistemas agroflorestais em pequenas propriedades e manejo sustentável na área da

\footnotetext{
15 “O Cadastro Ambiental Rural (CAR) é um registro eletrônico, obrigatório para todos os imóveis rurais, formando base de dados estratégica para o controle, monitoramento e combate ao desmatamento das florestas e demais formas de vegetação nativa do Brasil, bem como para planejamento ambiental e econômico dos imóveis rurais.”. (Disponível em: http://www.mma.gov.br/mma-em-numeros/cadastroambiental-rural)
} 
reserva legal. A área de reserva legal deve ser pelo menos $80 \%$ da propriedade agrícola na Amazônia Legal, 35\% da propriedade agrícola do Cerrado da Amazônia Legal e $20 \%$ da área da propriedade para as demais localidades.

$\mathrm{O}$ agricultor $\mathrm{A}$ disse que geralmente na área rural não tem água encanada, assim há de se preservar a nascente para poder beber a água, não desmatar em volta e delimitar a área para que os bichos não sujem a nascente. Ele completa:

Eu preciso de água pra beber e pra minha família, pros animais e pra usar na fazenda, pra isso eu preciso preservar as águas da minha fazenda. (...) Não tem discurso ecológico nenhum nisso é bem prático, mas é uma inteligência né, de entender a natureza.

Ainda sobre a preservação ambiental, o agricultor B relatou que para ele a agroecologia é a essência da vida e o trabalho dele, além da produção, é uma forma de reflorestar e tornar o ambiente melhor para todos. Já o agricultor D diz que para ele a preservação ambiental significa o equilíbrio nos seus sistemas produtivos.

Em todas as propriedades visitadas havia áreas recuperadas pós transição agroecológica, ou seja, após a mudança do sistema de produção convencional para o sistema de produção utilizando sistemas agroflorestais. No caso do agricultor A, a propriedade era convencional em praticamente toda a sua extensão, incluindo as lavouras e as pastagens. As áreas de pastagem eram bem degradadas, havia erosão e compactação superficial nas áreas do gado. Depois da implantação dos sistemas agroflorestais a propriedade possui agora cerca de 50 quilos de matéria orgânica por metro quadrado, segundo levantamento do próprio agricultor em 2005. Além disso, as áreas de gado estão em uma área arrendada (da propriedade dele), mas ele faz o manejo dessa área com plantio de consórcios de leguminosas para reequilibrar nutricionalmente o solo, além de deixar o solo em descanso sem que o gado utilize para recuperá-lo. Essa fala do agricultor A pode ser verificada na literatura em Moura et al. (2010, p. 08):

\footnotetext{
Quando uma área de pasto ou roça é deixada em descanso, sem animal pastando ou fogo por algum tempo, ela se refloresta naturalmente, o pasto vira capoeira, cerrado, cerradão ou floresta, sempre aumentando a diversidade e a quantidade de plantas e árvores.
}

Tanto o agricultor B quanto o D reconhecem que após a implantação dos sistemas agroflorestais eles não tem mais erosão e a água penetra abundantemente no solo. Em relação à água, o agricultor D relatou: 
A gente tem umas nascentes lá que quando começamos a trabalhar com orgânicos, a gente começou a reconstruir, pra plantar mudas nativas, fazer plantio ao redor [...] Hoje, a nascente jorra água, antes ela não jorrava. Ela jorrava água no tempo da chuva, hoje ela jorra água até na seca, o tempo todo. Porque plantou árvores ali, a gente começou a recuperar (a nascente), ela está lá, intacta lá. Hoje a gente viu a importância da preservação e todo esse trabalho que a gente veio fazendo, essa capacitação nossa, né? Como é importante a preservação do meio pra dar certo a produção.

Todos os agricultores afirmam a melhora da qualidade do solo pós transição agroecológica, principalmente nos aspectos relativos à quantidade de matéria orgânica do solo, a cor, a textura e a maior presença de insetos no solo. Uma prática indispensável citada pelo agricultor B é a utilização do adubo verde e do controle biológico. Essa prática é confirmada por Altieri (2014) quando o autor afirma que há metodologia adequada na agroecologia para a utilização de medidas drásticas, como inseticidas botânicos ou fertilizantes alternativos, para o controle de pragas específicos ou deficiências do solo. Assim como observado nas propriedades dos quatro agricultores, Peneireiro (1999, p. 96) destaca a importância dos sistemas agroflorestais na recuperação de áreas degradadas:

O Sistema Agroflorestal dirigido pela sucessão natural apresentou-se como um sistema de produção comprovadamente capaz de recuperar áreas degradadas, aliando produção à conservação, recuperação, manutenção, ou ainda, melhoria da qualidade, dos recursos naturais. 


\subsubsection{Dimensão Escala}

$\mathrm{Na}$ entrevista com o agricultor $\mathrm{A}$, verificou-se que o mesmo registra seu volume de produção semanal (figura 03). Em relação ao aumento da escala de produção, o agricultor A afirmou que vem investindo em mais áreas e melhorando a adubação, observando as peculiaridades de cada espécie. Por exemplo, quando afirma que "na área da banana, a cultura está em decréscimo de produtividade, porque é um talhão velho já, que tem que ser replantado". Ou seja, por enquanto não será necessário melhorar a área de adubação do bananal porque é uma área que em breve será plantada de novo pelo agricultor A, então ele prioriza as áreas das outras frutas.

O agricultor familiar B tem como principais produtos os tubérculos, sendo que quando era um produtor convencional (não orgânico) seu carro-chefe era o chuchu e agora é a cenoura, a banana e às vezes beterraba (figura 03). Verificou-se, porém, que o controle da organização da produção não é feito de forma sistemática.

$\mathrm{O}$ agricultor $\mathrm{C}$ tem como principais produtos as folhagens em geral: rúcula, agrião, couve, brócolis, couve-flor, couve-manteiga. Também produz mandioca, inhame, batata doce, banana, limão tahiti, morango, quiabo e milho (figura 03). Sobre isso o agricultor $\mathrm{C}$ discorre:

Como a gente trabalha com feira, né, então a gente tem muita variedade de produto, nosso mercado é esse, a variedade, não necessariamente tem que ter muita coisa de cada produto, e sim, variedade. (...) Então, o nosso foco é a diversidade, e nada melhor que a agrofloresta pra trabalhar com diversidade.

O agricultor familiar D também produz hortaliças em geral, principalmente folhagens (alface, rúcula), cenoura e morango (figura 03). Sobre sua produção o agricultor D afirma:

A gente já entrou dentro de um patamar assim de produção, de profissionalismo, que a coisa já está realmente planejada na cabeça, que não falta quase mais nada direto, sempre está tendo, então a gente sabe que se não plantar de 15 em 15 dias por exemplo, folhagem você não vai ter. (...) A gente chega a vender, por exemplo, volume de produção por semana, umas 100 caixas de mercadoria, de 20 quilos cada uma. Folhagem dá 10 quilos, né, metade. Dá até 120 por semana, cada família. 
Figura 03. Volume de comercialização de frutas, legumes, raízes e folhagens dos agricultores A, B, C e D

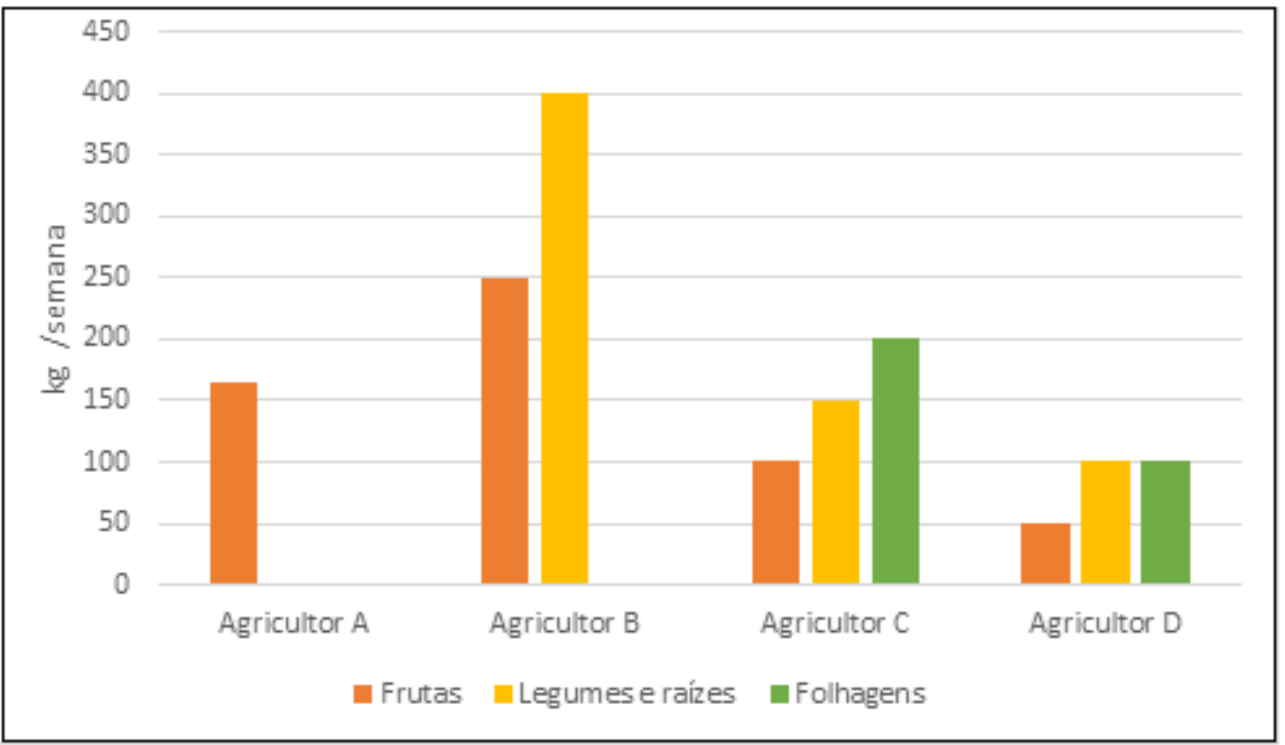

Em relação ao aumento da escala de produção, o agricultor familiar B destaca que trabalhava com produtos que necessitavam de mão-de-obra mais intensa e, por esse motivo, preferiu reduzir o número de culturas para facilitar a própria lida. Nas palavras dele:

É o seguinte, por falta de mão-de-obra, nós aumentou assim em termo. Porque por falta de mão-de-obra, eu mexia com folhosa, mexia com muita coisa mas dava muita mão-de-obra. Como eu só tenho familiar aqui e um funcionário só, eu optei em escolher algumas culturas que dá menos trabalho pra gente poder plantar. Então aumentou sim.

Sobre a organização da produção e venda, o agricultor $\mathrm{C}$ tem mais controle sobre a média mensal de rendimentos dos produtos vendidos, dependendo do produto, pois cada produto tem uma saída diferente e há épocas em que tem produto suficiente para vender, enquanto que em outras épocas não é possível ter produto suficiente para a venda. $\mathrm{O}$ agricultor $\mathrm{C}$ afirma que seu ganho de produtividade é maior, mesmo em comparação com outros agricultores que também trabalham com sistemas agroflorestais, pois ele replanta continuamente. Esta situação pode ser confirmada com a seguinte fala: 
A gente planta verdura várias vezes, no mesmo sistema, cheio de árvores, derrubando as árvores e plantando de novo, rebrotando e plantando de novo. Ninguém faz isso, todo mundo planta sua agrofloresta e só colhe uma vez a rúcula e o agrião, e depois fica esperando dois anos pra colher banana, cinco anos pra colher um pé de fruta, aí vai à falência.

A agricultura convencional por vezes reforça a premissa de que sua produtividade é maior que a da agricultura orgânica/agroecológica. Sobre isso Pat Mooney, 2006 apud Machado, Machado Filho, 2014, p. 41 destaca que:

Há várias pesquisas comparando a produção ecológica, sem veneno, com a produção do agronegócio. Invariavelmente, a produção agroecológica tem produtividade superior, entre $6 \%$ e $10 \%$.

As vantagens do plantio em sistemas agroflorestais ou policultivos é afirmado por Altieri (2012, p. 223) “[...] muito frequentemente é possível obter maiores produtividades numa área semeada em policultivo do que em área equivalente semeada com uma monocultura".

Segundo Machado e Machado Filho (2014) a escala é o volume de produção alcançado pelo agricultor familiar agroecológico. Observa-se que no caso dos quatro agricultores estudados, todos conseguem oferecer produtos semanalmente a seus clientes e com um volume de produção relativamente alto, a média de produtos comercializados pelos quatro agricultores foi de $141 \mathrm{~kg}$ de frutas por semana, $75 \mathrm{~kg}$ de folhagens por semana e $163 \mathrm{~kg}$ de legumes e raízes por semana. Assim todos os agricultores têm sua fala condizente com Moura et al. (2010, p. 42):

[...] Com a implantação de agroflorestas, há introdução de muitas espécies vegetais ao sistema de cultivo de forma gradual. São os consórcios, os policultivos, quebra-ventos, corredores de vegetação, áreas de plantio separadas por faixas de agroflorestas, módulos de agroflorestas com 50 ou mais espécies vegetais. Esse método irá fazer com que a produção melhore e aumente com o decorrer do tempo. O sistema agroflorestal baixa o custo da produção, pois são utilizados menos insumos (adubos e agrotóxicos). Melhora a produção, pois cria um ambiente propício para o desenvolvimento das plantas, possibilitando aumentar a renda com a venda de diferentes produtos em diferentes épocas.

O planejamento do plantio e organização de venda do agricultor D ainda é feito de forma bastante simplificada. Ele utiliza um caderno, onde escreve o que colheu, com as quantidades enviadas para cada ponto de venda. No fim do mês os dados desse caderno são sistematizados no computador, conforme relata o próprio agricultor:

Eu tenho esse controle no caderno, por exemplo assim, quando eu vou fechar o mês, eu vejo quem me pagou e isso aí tudinho. Aí eu lanço isso ou no computador, ou no outro caderno que daí eu faço o balanço do mês, que aí 
fica balanço de cada mês e aí no final do ano eu tenho o balanço de todo o ano.

Sobre a regularidade da oferta, a diversificação e a qualidade dos produtos observamos que todos os agricultores atendem esses requisitos que caracterizam as exigências do mercado de orgânicos/agroecológicos atualmente, como destacam Niederle e Almeida (2013, p. 26):

De fato, o que caracteriza este mercado atualmente é um processo de diversificação e segmentação de canais de comercialização, cada qual impondo um conjunto mais ou menos específico de exigências aos produtores: escala de produção, diversificação dos produtos, regularidade de entrega, padrões de qualidade etc.

O único agricultor que tem um controle preciso de organização da produção é o agricultor A, os agricultores, B e C relatam que tem o planejamento "na cabeça", enquanto que o agricultor D faz o controle de colheita e distribuição manual utilizando um caderno. Eles sabem mais o quanto venderam em termos de saquinhos e caixas de produtos, do que a organização antes disso do que plantaram. É interessante notar que a produção é diversificada e constante, porém os consumidores já sabem que encontrarão alimentos da época, por exemplo eles sabem que haverá morango para ser vendido na época certa do produto, diferentemente do mercado convencional. 


\subsubsection{Dimensão Social}

É importante observar que os canais de comercialização são destacados na dimensão social porque assim são citados na literatura utilizada para balizar esse estudo, para estudar como é o abastecimento local e regional por meio desses canais. Também observamos o aspecto da capilaridade desse alimento, no sentido de quais são os pontos de venda e quem são as pessoas que o consomem.

$\mathrm{O}$ agricultor A teve como primeiros pontos de venda uma feira e restaurantes na Asa Norte e na feira da Associação de Agricultura Ecológica (AGE). Atualmente, o agricultor A tem como pontos de venda a Cooperativa do Mercado Orgânico, situada na Central de Abastecimento do Distrito Federal (CEASA) e uma loja que vende produtos orgânicos na asa norte (Figura 04).

Figura 04. Canais de comercialização do Agricultor Familiar A

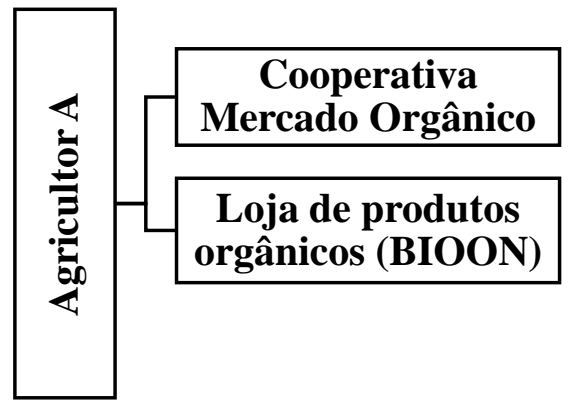

Em relação à forma como o agricultor conseguiu escoar sua produção, destacase que as redes de confiança e relacionamento foram essenciais, conforme afirmado por ele na entrevista:

(...) o Mercado Orgânico, eu conheci uma agricultora que era produtora lá e perguntei pra ela se eu podia me cooperar lá, ela falou que podia. Então chegou um momento que eu fui lá e me cooperei. Depois, a loja Bioon. Quando eles abriram a loja que ia ter frutas, eu já conhecia eles e eles me convidaram pra entregar lá.

O agricultor relata que há alguns anos já comercializou seus produtos em um ponto de feira na Asa Norte durante seis meses, porém não possuía escala de vendas suficiente e nem disponibilidade para estar presente durante o tempo necessário para 
vender os produtos na feira. Dessa forma, ele afirma que os pontos do Mercado Orgânico e a loja Bioon são mais interessantes para a comercialização de seus produtos, pois sozinhos já representam um grande volume de suas vendas. Assim, o agricultor destaca:

\begin{abstract}
Eu não tenho interesse nem condição de fazer feira ou abrir um ponto de comercialização direta, porque é muito trabalho. Então eu estou optando por canais indiretos de comercialização, através de lojas, de cooperativas, de instituições que faça essa ponte até o cliente e distribuição. Porque mesmo delivery né, também é outra logística complexa.
\end{abstract}

Alguns autores (SABOURIN et al., 2014; NIEDERLE, ALMEIDA e VEZZANI, 2013) afirmam que a relação entre agricultores e consumidores é uma relação de proximidade quando a comercialização é feita de forma direta, principalmente em feiras livres, porém observa-se a fala do agricultor A:

Geralmente eles passam dão um 'bom-dia' e vão embora. Não tem um que pare e fique conversando. E assim, tem o fato de estabelecer uma relação de amizade numa feira ainda, assim isso ainda está muito longe de realmente conhecer a realidade do campo.

Percebe-se na fala do agricultor A que ele não concorda com a afirmação de autores (SABOURIN et al., 2014; NIEDERLE, ALMEIDA e VEZZANI, 2013) que a comercialização direta permite ou cria uma relação de proximidade, pois os consumidores que ele atende são impessoais e apenas compram os produtos.

Sobre a motivação do consumidor para comprar produtos orgânicos e/ou agroecológicos, o agricultor A afirma que a justificativa da compra seria pela saúde e por "modismo", já a motivação de produção do próprio agricultor seria pela segurança dele e de sua família (no manejo e comercialização dos produtos). Discorre assim:

Esses dois aspectos. E pra um agricultor (trabalhar) com isso no meu ver tem dois aspectos, o financeiro e pessoas que já passaram por problemas de intoxicação muito sério na família, ou coisa assim. Então tiveram que mudar pra um sistema de produção agroecológico por uma questão de segurança da própria família, né? Tem esses dois aspectos que eu tenho visto.

$\mathrm{O}$ agricultor B teve como primeiros pontos de venda o Espaço Natural e o Empório Malunga. Atualmente, às vezes fornece para a fazenda Malunga, para a loja de orgânicos BIOON e também vende seus produtos junto com outros agricultores pertencentes a um grupo de agroecologia que escoa a produção na Feira da Estação Biológica (FOEB) em frente à Emater, localizado na Asa Norte. Também escoa sua produção por meio dos mercados institucionais, sendo que participa do PAA desde o 
início do programa e entregou para o PAPA somente no ano passado (2014). O canal de comercialização do agricultor B está descrito na Figura 05.

Figura 05. Canais de comercialização do Agricultor Familiar B

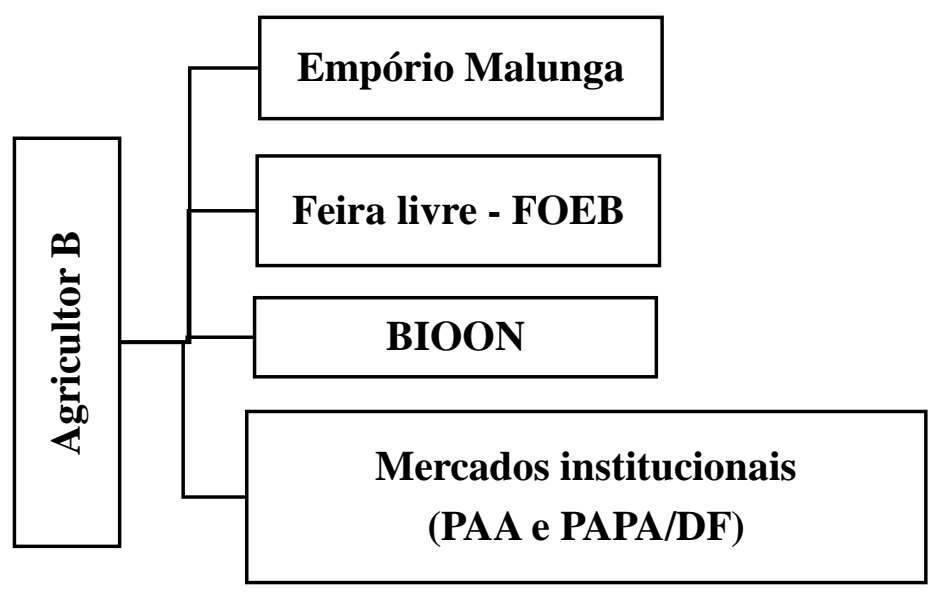

Sobre o relacionamento com os consumidores, o agricultor B destaca que de todos os seus compradores, só conhece mesmo os clientes da feira livre. Sobre esta relação, comenta " Tem alguns desses que a gente se torna amigos, a relação é boa, muito boa. E tem alguns deles que já vieram aqui. [...] Às vezes a gente convida também se a pessoa quiser conhecer a propriedade, ver da onde vem o produto". Nessa fala do agricultor B podemos verificar que confirma a relação de amizade que está na teoria, quando Sabourin et al. (2014, p. 104) afirmam que:

Tais situações de contato direto dão lugar a relações humanas (conversas e explicações em torno do produto, dos processos, das receitas) que geram também sentimentos de proximidade, amizade e valores de confiança e de fidelidade entre produtor e consumidor.

Já o agricultor familiar $\mathrm{C}$ teve como primeiros pontos de venda o restaurante Girassol, na Asa Sul, e o mercado orgânico da Ceasa, esses dois pontos antes da certificação. Após conseguir o certificado de agricultor familiar, iniciou a comercialização na feirinha orgânica em frente à Emater. Atualmente comercializa nessa feira livre mencionada, na feira livre do Lago Norte, na feira da AGE na asa norte, na feira livre do Ibram na 511 norte, na loja de orgânicos BIOON, além de participar dos programas de entrega de produtos da agricultura familiar, o Programa de Aquisição de Alimentos (PAA) e o Programa de Aquisição de produtos da Agricultura Familiar 
(PAPA-DF). Os canais de comercialização do agricultor $\mathrm{C}$ estão esquematizados na Figura 06.

Figura 06. Canais de comercialização do Agricultor Familiar C

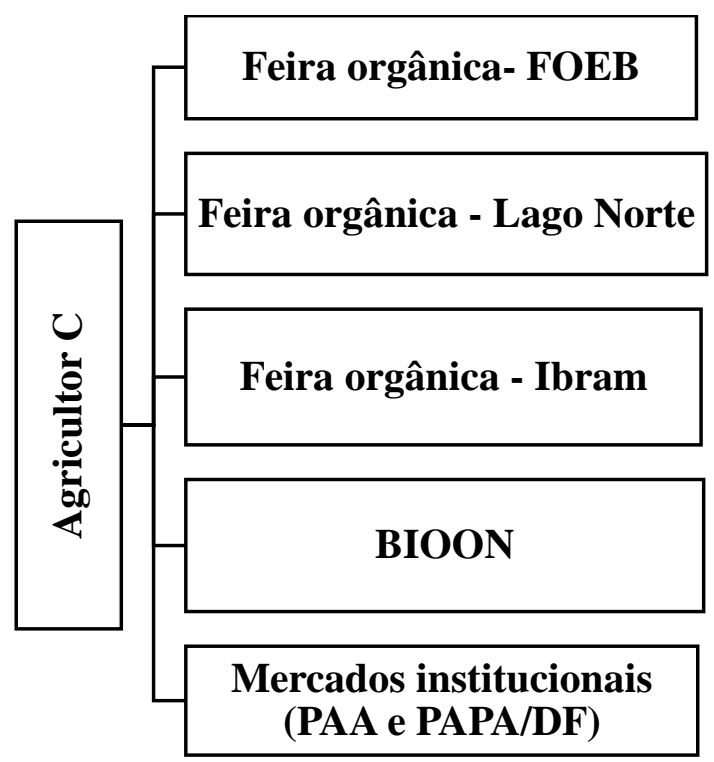

Sobre como conseguiu comercializar nesses locais, o agricultor $\mathrm{C}$ relata:

Na verdade, a gente correu atrás, né? A gente que abriu a feira do Lago Norte e a gente que abriu a feira do Ibram, então foi a gente que foi atrás $e$ pediu, as pessoas queriam também.

Sobre a possibilidade da feira livre aproximar mais agricultores e consumidores, o agricultor $\mathrm{C}$ não responde assertivamente e discorre:

Tem desde os amigos, pessoais, que vão na feira até pessoas que eu não conheço, não falo, só “oi, bom dia”, então (tem pessoas) de todos os tipos. Tem pessoas que se tornaram amigos pela frequência na feira, aí tem pessoas que só sabem que o produto é orgânico igual a qualquer feira, não sabe o que é agrofloresta. [...] Na feira tem sete, oito produtores, (mas) só nós dois trabalhamos com agrofloresta no grupo. (O consumidor) sabe que o produto agroflorestal é melhor, melhor pro planeta e melhor pra ele.

$\mathrm{O}$ agricultor $\mathrm{C}$ relata que se tornou amigo de clientes que são frequentes na feira o que reforça o argumento de relação de proximidade também segundo Sabourin et al., 2014; Nierdele, Almeida e Vezzani, 2013.

$\mathrm{O}$ agricultor $\mathrm{D}$ teve como primeiros pontos de comercialização algumas bancas de feira livre na Universidade de Brasília, Campus Darcy Ribeiro (Asa Norte), um ponto de venda no Ministério do Meio Ambiente, um ponto de venda no Ministério do 
Desenvolvimento Agrário e um ponto de venda na Universidade Católica de Brasília, em Taguatinga. Hoje, o grupo de agricultores do Assentamento Colônia I, denominado Grupo Vida e Preservação (GVP) tem como locais de venda (Figura 07) as feiras livres na UnB, no Ministério do Meio Ambiente (quadra 505 norte), no Ministério do Desenvolvimento Agrário, na quadra 305 norte e aos sábados a feira da 302 norte.

Figura 07. Canais de comercialização do Agricultor Familiar D

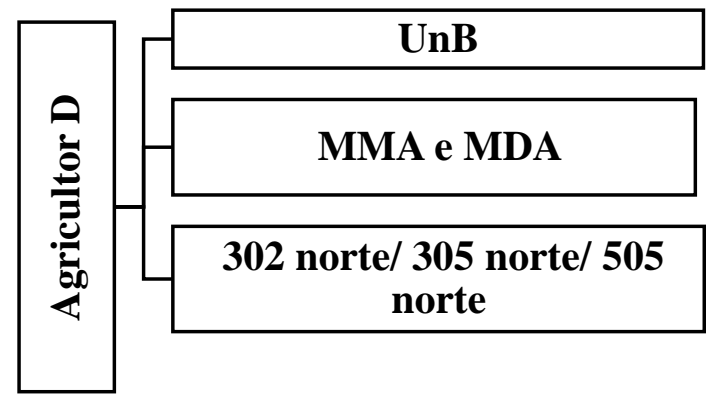

$\mathrm{O}$ agricultor familiar D explica que o assentamento fazia parte de um projeto para que eles plantassem para subsistência, mas quando a produção começou a ter excedente eles tiveram a ideia de comercializar, conforme relata:

\begin{abstract}
A proposta do projeto que a gente conseguiu na época era fazer pra subsistência, né? Produção para consumo das famílias envolvidas. Quando a gente viu que tinha excedente, então a gente viu que a gente tem que fazer e vender, porque a gente vai perder alface, perder um monte de coisa e a gente tem que fazer isso virar dinheiro.
\end{abstract}

Sobre a relação de proximidade com os consumidores, assim como afirmaram os agricultores $\mathrm{B}$ e $\mathrm{C}$, o agricultor $\mathrm{D}$ afirmou que conhece e tem relação de confiança e amizade com muitos de seus clientes. Como podemos verificar na seguinte fala:

Eu sei 80, 90\% quem são meus compradores. Eu sei quando eles somem, quando eles aparecem. Quando aparece um novo eu sei que é diferente, aquele ali eu conheço aquele ali é o Guilherme. Eu acho assim, que a gente consegue fazer uma relação boa, de conversar, de amizade, de brincar, de receber. Aquele lá tá me devendo uma visita, até hoje não foi, mas a gente consegue receber visitas deles, a gente faz esse trabalho.. Eu tenho uma cliente que o filho dela vai pra minha casa pra poder passear. Agora você imagina a relação, é mais do que produtor, venda e comércio, é uma relação familiar mesmo. 
Sabourin et al. (2014, p.103) destaca então a relação entre venda direta e as relações de troca entre o agricultor/produtor e o consumidor:

A venda direta é uma prática comercial que permite o encontro entre o produtor e o consumidor na unidade de produção, na feira do produtor ou nos mercados de proximidade. Existe sim uma relação de troca; mas o contato direto entre produtor e comprador permite redobrar essa relação de troca em uma relação de reciprocidade binária (de cara a cara) que gera, no mínimo, valores afetivos: sentimentos de conhecimento mútuo, de reconhecimento mútuo e até de amizade ou valores éticos de respeito mútuo e de fidelidade.

E ainda nesse sentido de reciprocidade binária, Sabourin et al. (2014, p. 102) destaca que "[...] a relação de reciprocidade em uma estrutura bilateral simétrica gera um sentimento de amizade".

O agricultor familiar D afirma que vê como benefícios de comercializar sua produção em feiras orgânicas o contato direto com o consumidor e principalmente o fato de poder praticar um preço satisfatório tanto para eles quanto para o consumidor. A maior dificuldade que ele aponta é a logística para sair do assentamento e chegar bem cedo nos locais das feiras livres, assim como o atendimento em momentos de pico, quando há muitos clientes querendo ser atendidos ao mesmo tempo. Verificamos nas falas:

Os benefícios é que você tem contato direto com o consumidor, você pode vender diretamente com um preço justo pro agricultor e justo pro consumidor. Por exemplo, hoje, um alface aqui é R\$2,50. Se você for no Oba (mercado) hoje comprar (um alface) da Malunga deve estar no mínimo uns $R \$ 3,80$, jogando baixo, $R \$ 4,00$ reais a média. Então, imagina, eu vendendo esse alface a $R \$ 2,50$ pro cliente, e ele podia comprar a um tal valor, quase o dobro, entendeu? Pra mim é um preço satisfatório, pra mim um pé de alface $R \$ 2,50$ é muito dinheiro. A gente vê que é uma grana boa e pro consumidor é pouco, tá pagando pouco, é orgânico.

O que dificulta pra mim é os horários, muito cedo. Tem que chegar muito cedo nas feiras, tipo sair de casa umas 02h30,02h40, aí eu acho mais difícil. E muita gente ao mesmo tempo, quando vem, vem todo mundo ao mesmo tempo, você viu aí dez, quinze pessoas. Tem dia que junta vinte pessoas, aí duas pessoas aqui, não consegue (atender).

Essa venda direta entre o agricultor e o consumidor final pode ser compreendida como circuitos curtos de comercialização (CC). Os circuitos curtos ${ }^{16}$ têm sido uma tendência emergente no mundo, em sua origem estiveram vinculados a

\footnotetext{
16 Segundo o boletim da CEPAL-FAO-IICA (2014, p.02), a primeira vez que o conceito formal de circuitos curtos apareceu foi: “Em 1965, no Japão, quando um grupo de mães de família, preocupadas pela industrialização da agricultura e o uso massivo de produtos químicos, fundaram as primeiras alianças (teikei) com produtores que se comprometiam a produzir alimentos sem produtos químicos. Em troca disso, as mulheres asseguravam a compra da colheita, por meio de associação a essas "teikel". ". (tradução livre)
} 
relações de proximidade, no sentido dos consumidores estarem buscando um contato direto com os produtores e, a geração de relação de confiança com o produtor (CEPALFAO-IICA, 2014). Essa construção de circuitos curtos que ligam a produção e o consumo do alimento também ligam a agricultura e a sociedade regional, diferentemente do modelo tradicional que é baseado em grandes empresas de processamento e comercialização, que cada dia mais trabalham em escala global (VAN DER PLOEG, 2008b).

Segundo o agricultor D, os consumidores valorizam o alimento agroecológico pois além de perceberem a maior qualidade desses alimentos, também sabem que é mais barato para eles do que se comprassem em mercados ou supermercados - onde o preço é maior, principalmente pela logística que o alimento percorre. Além do lado do consumidor, o agricultor D discorre que para ele o valor que cobra sobre seus produtos é justo e suficiente para cobrir seus custos de produção e continuar trabalhando com agricultura. $\mathrm{O}$ agricultor $\mathrm{A}$ afirma que os consumidores compram produtos orgânicos/agroecológicos tanto pela saúde quanto pelo "modismo". Já o agricultor C afirma que são as mulheres as maiores compradoras dos alimentos orgânicos/agroecológicos. Esse assunto será abordado mais detalhadamente na dimensão econômica quando há a questão da motivação de compra. 


\subsubsection{Dimensão Econômica}

Nessa dimensão não foram trabalhados aspectos financeiros em si, como a renda explícita dos agricultores. O intuito foi principalmente verificar se a atividade agrícola era a principal atividade do agricultor, e em todos os casos foi verificado que não só a produção em si, mas o conhecimento técnico em sistemas agroflorestais permite que todos eles tenham renda também com cursos e palestras que oferecem pelo tema.

Quadro 05. Principais fontes de renda dos agricultores A, B, C e D.

\begin{tabular}{|l|c|c|c|c|}
\hline & $\begin{array}{c}\text { Produtos } \\
\text { agroecológicos }\end{array}$ & $\begin{array}{c}\text { Visitas à } \\
\text { propriedade }\end{array}$ & Curso de SAFs & Consultorias \\
\hline Agricultor A & $\mathrm{X}$ & & & $\mathrm{X}$ \\
\hline Agricultor B & $\mathrm{X}$ & $\mathrm{X}$ & $\mathrm{X}$ & $\mathrm{X}$ \\
\hline Agricultor C & $\mathrm{X}$ & $\mathrm{X}$ & & \\
\hline Agricultor D & $\mathrm{X}$ & $\mathrm{X}$ & \\
\hline
\end{tabular}

Dos três agricultores familiares entrevistados apenas o agricultor A não tem como principal fonte de renda a agricultura. Esse agricultor A tem como principal fonte de sustento a consultoria em sistemas agroflorestais/agroecológicos, mas pretende ter no futuro maior renda com sua produção agroecológica. O agricultor A destaca:

\footnotetext{
Eu não sei se vai ser minha principal renda (no futuro), mas assim eu tenho uma visão mais pragmática desse assunto, é um negócio eu tô investindo, tenho três hectares em produção. $O$ ponto de equilíbrio desse negócio é de cinco a sete hectares, inclusive eu tenho que investir mais aí uns quatro hectares. Então eu preciso investir uns 150 mil reais nos próximos dois, três anos pra chegar em um ponto de equilíbrio. (...) Eu acho que a agricultura familiar tem que olhar pra propriedade que eles têm como um negócio.
}

Em relação ao direcionamento do lucro das vendas na propriedade, as respostas são diversas. $\mathrm{O}$ agricultor $\mathrm{B}$ afirma que se tem dinheiro tem mercadoria e se tem mercadoria tem dinheiro, ele justifica citando os custos de produção, pagamento de funcionário e logística. Assim, quando consegue produzir e vender o que produz, consequentemente ele consegue realimentar o sistema. $\mathrm{O}$ agricultor $\mathrm{C}$ afirma que não detalha exatamente onde investe o dinheiro que entra na propriedade, pois ele às vezes utiliza um valor recebido nos cursos de capacitação que oferece na propriedade, outras vezes recebe o dinheiro de um produto e usa para fazer um gasto pessoal. Dessa forma, ele está contando com o auxílio de uma pesquisadora da Embrapa Cerrados, que por 
meio de um projeto, está organizando as finanças do sítio. $\mathrm{O}$ agricultor $\mathrm{D}$ destaca que boa parte do dinheiro recebido na venda dos produtos agroecológicos são investidos em melhorias na propriedade, ele cita como exemplo o poço artesanal, a irrigação, uma bomba trifásica e o caminhão. Além desses investimentos, ele destaca que também há os custos de adubação, produção e pessoal para trabalhar.

Os agricultores familiares que trabalham principalmente com a produção e venda de produtos agroecológicos são os agricultores B e D, no entanto o agricultor D também recebe grupos diversos para visitar a propriedade e isso também contribui com a renda dele. Como já descrito anteriormente, o agricultor A trabalha também com consultoria e o agricultor $\mathrm{C}$, além da comercialização de produtos agroecológicos, também oferece cursos de capacitação em sistemas agroflorestais na sua propriedade. Sobre isso ele diz "O principal é, o foco do meu investimento é a produção, a qualidade do sistema e consequentemente tem as capacitações, as visitas, e as consultorias que vêm na sequência pra fora (do sítio)".

Todos os agricultores afirmam que sempre tem produto para oferecer ao consumidor. E sobre o método de organização os agricultores B e D afirmam que anotam em cadernos o que plantam e o que colhem. Os produtos de todos os agricultores são vendidos in natura e lavados, não são vendidos minimamente processados porque para isso seria necessária uma estrutura de packing house ${ }^{17}$ e eles ainda não tem capital nem autorização para fazê-lo. Nesse sentido, o único agricultor que vende seus produtos embalados é o agricultor $C$, pois ele afirma que é uma exigência da certificação orgânica.

Com relação ao entendimento dos agricultores familiares sobre o interesse dos consumidores por produtos orgânicos/agroecológicos, houve vários relatos diferentes. $\mathrm{O}$ agricultor $\mathrm{C}$ afirmou que percebe que a maioria dos consumidores das feiras livres onde comercializa são mulheres e ele afirmou que elas compram seguindo critérios de organização e de "beleza" dos produtos, ele disse que "a mulher compra com o olho". O agricultor D relatou que seus consumidores apontam a durabilidade, a qualidade da textura e o sabor dos seus produtos agroecológicos. Uma fala diferente é a do agricultor A que pensa que os consumidores querem comprar produtos sem veneno e pelo menor preço que puderem pagar. Assim destaca o agricultor A:

17 É uma unidade de beneficiamento, uma estrutura com instalações que atendam às exigências fitossanitárias. 
Os consumidores tão muito longe da realidade da agricultura, eles não sabem de nada, eles só querem pagar o mais barato possível e comer sem veneno. (...) Não é porque é orgânico ou agroecológico que estreitou as relações entre cidade e meio rural.

As motivações apresentadas pelos consumidores, para o consumo de alimentos orgânicos é diverso na literatura. Porém, recente estudo da Codeplan no Distrito Federal destaca alguns pontos pertinentes, assim segundo Gonçalves, Rolim e Rosa (2016, p. 19):

\begin{abstract}
As razões que levam as pessoas a consumirem produtos orgânicos são inúmeras e diversas, não restringindo apenas a hábitos pessoais e familiares. [...] A preocupação com a sustentabilidade e inclusão social, também, são marcantes entre os consumidores fiéis deste nicho. [...] Ainda, entre as variáveis importantes que condicionam a demanda por orgânicos, renda e preço são consideradas as de maior relevância na hora da compra.
\end{abstract}

Essa citação corrobora com a fala do agricultor D que sinaliza principalmente a questão do preço. Já os agricultores C e D destacam os aspectos extrínsecos dos produtos ao relatar a percepção deles sobre a motivação dos consumidores de seus produtos. O autor Darolt (2007, p.31) afirma que "[...] 66\% dos consumidores de orgânicos são do sexo feminino", assim como destacou o agricultor C.

Todos os agricultores familiares afirmaram que gostariam de continuar vivendo de agricultura no futuro. Sobre esse assunto, o agricultor A afirma que a agricultura é um negócio economicamente viável e que, com o tempo, ele terá estruturado melhor sua produção e propriedade, pois além da fruticultura, ele pretende agregar madeiras para serem colhidas em longo prazo. Já o agricultor $\mathrm{C}$ afirma que pretende aumentar sua área de produção, porém permanecendo na categoria de agricultura familiar, relatando o seguinte:

[...] não tenho interesse em virar um médio produtor. Eu quero ser um agricultor familiar, eu prefiro, porque eu acredito na agricultura familiar com muita força, então o meu trabalho é realmente mostrar que esse trabalho é viável para agricultura familiar, principalmente.

É interessante notar a visão distinta que cada um dos agricultores tem de sua produção. Enquanto o agricultor A ressalta que os agricultores familiares precisam ver sua propriedade como um negócio (porém ainda não vive apenas da agricultura tendo como maior renda a consultoria na área de SAFs), o agricultor $\mathrm{C}$ pretende aumentar a área de produção, mas só o necessário, pois relata que não quer tornar-se um médio produtor porque acredita na agricultura familiar. O agricultor B na entrevista, quando 
perguntado sobre perspectivas futuras, respondeu veementemente com alegria e disposição querer permanecer como agricultor familiar enquanto puder. O agricultor D é um caso também diferente, pois é assentado e filho de assentado da reforma agrária, iniciou a produção convencional de subsistência, passou pela transição agroecológica e atualmente produz em SAFs e vive da comercialização dos seus produtos também querendo continuar sendo agricultor familiar no futuro. 


\subsubsection{Dimensão Política}

A utilização de algumas políticas públicas foi identificada na pesquisa, conforme o quadro 04. Segundo Niederle e Almeida (2013, p. 49):

[...]reconhecem-se os mercados institucionais como circuitos de venda direta em que a qualidade do produto é assegurada pela confiança produzida na recorrência das relações entre os agricultores familiares e consumidores beneficiários.

Os mercados institucionais, na figura do programa nacional PAA e do programa distrital PAPA-DF são acessados pelos agricultores B e C. O agricultor D elogia o funcionamento do PAPA-DF e comenta que já participou por meio de uma cooperativa que envolvia agricultores do DF e da região do Entorno, mas afirma que não consegue acessar o PAPA-GO e nem o PNAE por questões de pouca oferta de produtos.

Os mecanismos de intervenção pública, nesse trabalho os próprios mercados institucionais, podem ser percebidos também como mercados aninhados, assim explicam o conceito Schmitt e Grisa (2013, p.231): [...] “mercados encaixados" (nested markets), ou seja, segmentos diferenciados de mercado que se encontram imbricados em um mercado mais amplo, possuindo fronteiras mais ou menos permeáveis".

Quadro 04. Políticas públicas (PAA, PAPA-DF, PRONAF, Mais Alimentos e Prospera) acessadas pelos agricultores A, B, C e D.

\begin{tabular}{|l|c|c|c|c|c|}
\hline & PAA & PAPA-DF & PRONAF & Mais Alimentos & Prospera \\
\hline Agricultor A & & & $\mathrm{X}$ & & \\
\hline Agricultor B & $\mathrm{X}$ & $\mathrm{X}$ & & & \\
\hline Agricultor C & $\mathrm{X}$ & $\mathrm{X}$ & $\mathrm{X}$ & $\mathrm{X}$ & $\mathrm{X}$ \\
\hline Agricultor D & & $\mathrm{X}$ & & & \\
\hline
\end{tabular}

Em relação a programas de governo, de financiamento e subsídio para a produção, o agricultor $\mathrm{C}$ explicita que utilizou o Pronaf para o plantio e para adquirir um automóvel, além do programa Mais Alimentos ${ }^{18}$ para a produção também. Na esfera

${ }^{18}$ O programa Mais Alimentos é uma linha de crédito do Pronaf para financiar investimentos em infraestrutura produtiva da propriedade. 
distrital utiliza o subsídio do Prospera ${ }^{19}$ para fazer a manutenção dos bananais. O agricultor A também utilizou recursos do Pronaf para adquirir um automóvel e para manutenção da produção. Os demais agricultores não mencionaram utilização de financiamentos governamentais em suas propriedades.

O agricultor familiar A relata que participou de diversos cursos sobre sistemas agroflorestais e agroecologia antes de, de fato, implementar de forma contínua essas técnicas em sua propriedade. $\mathrm{O}$ agricultor confirma:

\begin{abstract}
Teve alguns né (cursos de capacitação). Na verdade, o conhecimento técnico que o produtor rural precisa pra trabalhar com sistema agroflorestal ele demora alguns anos pra formar isso. Tem que fazer alguns cursos, algumas áreas experimentais, tem que estudar, tem que começar a inserir isso dentro da história da fazenda dele. Eu passei assim uns três anos fazendo experimentos, fazendo curso com o Ernst. Eu comecei a plantar sistemas comerciais mesmo em 2006.
\end{abstract}

Segundo o agricultor familiar A, ele não contou com auxílio de nenhuma instituição pública de ensino, pesquisa, extensão ou fomento para a sua produção e afirmou que para ele a agroecologia é uma área em que ainda há a necessidade de mais mão de obra especializada. Porém, percebe-se que como ele é consultor na área e já possui vasta experiência com Sistemas Agroflorestais, talvez as instituições existentes não corresponderam às suas expectativas porque ele considera possuir mais conhecimento que elas.

Tanto o agricultor A quanto o agricultor $\mathrm{C}$ tiveram seu contato inicial com sistemas agroflorestais e, portanto, com o conceito de agroecologia principalmente a partir de cursos com o suíço Ernst Gotsch em Alto Paraíso - Goiás. Já os agricultores B e D tiveram auxílio de instituições públicas para iniciar a produção agroecológica. O agricultor B teve a propriedade escolhida como unidade demonstrativa para um curso de iniciação à Agroecologia para agricultores familiares desenvolvido pela Emater-DF. Já o agricultor D teve como principal impulsionador a própria Universidade de Brasília, por meio de um curso de extensão, além de apoio da Emater-DF da Embrapa, o agricultor D destaca que não teve uma capacitação oficial, mas houve orientação e participação das duas instituições nas atividades de produção orgânica/agroecológica.

Outro fator decisivo na implantação da produção orgânica foi um projeto oferecido pela UnB, no qual filhos de assentados eram selecionados para estudar em um curso de técnico agropecuário na Escola de Unaí. Dois jovens do Assentamento Colônia

\footnotetext{
${ }^{19}$ O Prospera é um programa de microcrédito para pequenos empreendedores do DF e Entorno oferecido pelo Banco de Brasília - BRB.
} 
I foram selecionados, entre eles o próprio agricultor entrevistado Wátila. Segundo ele, o curso foi essencial para colocar em prática os conhecimentos e a organização da comunidade em associação e cooperativa.

Os serviços de apoio são citados pelos agricultores assim como em outro estudo sobre agricultura orgânica e agroecológica, onde Sabourin et al. (2014, p. 112) destaca:

\begin{abstract}
A aproximação entre produtores orgânicos de diversas origens e as suas relações com os serviços de apoio (EMATER, EMBRAPA, SEBRAE), aparece também nas entrevistas como fonte de aprendizagem e de inovações. Embora a Embrapa e a Emater proponham uma "invenção", é o produtor (muitas vezes em interação com outros colegas) quem realiza a adaptação da proposta técnica às condições reais, quer dizer, o processo de "inovação". Quanto às técnicas de produção, todos os entrevistados confirmam a importância do compartilhamento de saberes e da transmissão de conhecimentos "boca a boca", dentro do conjunto da cadeia.
\end{abstract}

Todos os agricultores familiares estudados participam de cooperativas. $\mathrm{O}$ agricultor A faz parte da Cooperativa do Mercado Orgânico na CEASA. Os agricultores B e C fazem parte de uma Cooperativa chamada Agroorgânica. E, por fim, o agricultor D faz parte da Cooperativa de agricultores agroecológicos do Assentamento Colônia I (Coopafama) e região.

Dentro do Assentamento Colônia I existem dois grupos de produção, o grupo Vida e Preservação, que trabalha com produtos orgânicos e o grupo de mulheres chamado Sabor do Cerrado, que produz biscoitos e doces a partir de frutos do Cerrado, além de prestarem o serviço de buffet em eventos e reuniões. Em relação a forma de organização e comercialização do agricultor D destacamos a seguinte análise de Sabourin et al. (2014, p. 113):

No grupo Vida e Preservação, os produtores beneficiam das vantagens de uma estrutura formal como membros da COOPAFAMA, a cooperativa do assentamento e tem acesso às compras públicas do PAA e PNAE, e a certos créditos subsidiados. Mas preservam a sua liberdade de gestão, organização e decisão, mediante a flexibilidade do grupo informal do GPV para a venda direta. Os excedentes são processados pelo grupo de mulheres integrado a rede "Sabores do Cerrado".

Sobre estar envolvido em associações ou grupo de estudos que discutem os princípios agroecológicos, o agricultor B afirma que pelo fato de sua propriedade ser uma chácara demonstrativa, ele recebe muitos grupos de estudos da Embrapa e da Emater, estando, dessa forma, envolvido com os estudos dos princípios agroecológicos. $\mathrm{O}$ agricultor C relata que criou a Asprosaf - Associação dos produtores agroflorestais 
com o intuito de aprovar projetos de educação agroflorestal e também de gênero dentro da agricultura familiar. Já o agricultor D explicou que existem reuniões a cada dois meses em que eles decidem a programação de plantio e venda, além de resolução de problemas que por ventura apareçam, sendo que essas reuniões são feitas com a presença dos jovens do Assentamento. Ele destaca "A gente toma uma decisão (na reunião), como tudo nosso é coletivo. Somos referência em trabalho coletivo, né, de produção agroecológica em Brasília e no Goiás”.

A assistência pública, na figura das instituições de assistência técnica e extensão rural, assim como também de pesquisa e extensão - Emater, Embrapa e no caso do DF, a Universidade de Brasília - destacaram-se nesse trabalho como fundamentais no sucesso dos empreendimentos rurais dos agricultores familiares A, B, C e D. 


\section{CONSIDERAÇÕES FINAIS}

A agroecologia não busca uma ruptura completa do sistema econômico vigente, apesar de autores como Machado e Machado Filho (2014) acreditarem que a agroecologia em sua totalidade só é possível além do capitalismo. A agroecologia é mais abrangente que os conceitos de agricultura alternativa, maior que o conceito de sistemas agrícolas ou técnicas específicas, como a agricultura orgânica e os sistemas agroflorestais. Para o mundo acadêmico e não acadêmico também, ainda é vista de forma utópica e como se estivesse na esfera do "ideal".

Ao analisar as respostas dos agricultores no que tange a autodenominação deles entre orgânico ou agroecológico ficou evidente que eles buscavam aspectos práticos para balizar suas respostas. Dois agricultores - A e C - enfatizaram que se consideravam orgânicos por causa da certificação que possuíam e agroecológicos devido a produção em sistemas agroflorestais, enquanto que o agricultor B relatou que era tanto orgânico quanto agroecológico, porque para ele os SAFs eram agroecológicos e as folhagens orgânicas. $\mathrm{O}$ agricultor $\mathrm{D}$ considerou-se agroecológico pois sua produção vai além de aspectos de comercialização.

Os agricultores familiares estudados nessa dissertação são um recorte da heterogeneidade da categoria tanto no DF quanto no país, dessa forma podemos destacar as diferenças base e estruturais entre eles. O agricultor A que estudou aspectos técnicos da agricultura a partir da formação em agronomia e mestrado em agronegócios, também estudou os sistemas agroflorestais com Ernst Götsch. Esse agricultor tem como principal renda a consultoria, porém pretende continuar trabalhando para ter como principal renda, a agricultura. O agricultor B tem formação superior em Ciências Biológicas e também estudou sistemas agroflorestais com Ernst Götsch. Ele tem como renda principalmente a agricultura, além de oferecer cursos de manejo em SAfs na propriedade. $\mathrm{O}$ agricultor $\mathrm{C}$ tem o ensino fundamental incompleto e é o caso clássico de agricultor familiar que era convencional e passou pela transição agroecológica, com essencial apoio de instituições de assistência técnica e extensão rural (Emater e Embrapa). Ele é o agricultor que tem o maior volume de produção de frutas, legumes, raízes e folhagens entre todos os agricultores estudados. O agricultor D é licenciado em Educação do Campo, aqui temos o caso de um agricultor assentado que passou pela fase inicial de produção de subsistência, depois produção convencional seguida de transição agroecológica para consumo e comercialização. 
O Distrito Federal tem uma renda per capita entre as mais altas do país, e também sofre com a concentração fundiária. O DF é cercado pelas pastagens e paisagens monoculturais do agronegócio, mas há iniciativas de agricultores familiares produzindo em sistemas orgânicos e agroecológicos. Assim, possuímos um mercado em franca expansão e consumidores que procuram por esse tipo de alimento. Hoje a demanda no DF por produtos orgânicos/agroecológicos ainda é maior que a oferta desses produtos.

Um ponto importante observado foram as iniciativas dos agricultores quanto ao escoamento de seus produtos nas feiras orgânicas e a forma como colaboram uns com os outros na divisão de produtos para a venda (principalmente os agricultores B, C e D). Outro aspecto importante foi a real utilização dos mercados institucionais, essencialmente o PAA e o PAPA-DF para a comercialização dos produtos de três dos quatro agricultores estudados, o que reforça o quanto essas políticas públicas são necessárias para os agricultores familiares.

O apoio de instituições de assistência técnica e extensão rural e também instituições de ensino foram fundamentais no processo de transição agroecológica dos agricultores B e D. A interdependência das dimensões ambiental, escala, social, econômica e política foi verificada nas falas de todos os agricultores. Não reduzir a importância de nenhuma dessas dimensões é fundamental para tentar compreender de forma holística como elas influenciam totalmente a busca pela sustentabilidade.

Muito mais que o aspecto econômico, a perspectiva de no futuro continuar trabalhando com a agroecologia reforça o comprometimento dos agricultores familiares com o seu trabalho e com uma causa maior. Por um lado, na esfera pragmática, eles contribuem com abastecimento local de alimentos orgânicos/agroecológicos e por outro lado, na esfera do ideal, contribuem para o meio ambiente por meio de uma produção limpa, sem se afastar da tríade do socialmente justo, economicamente viável e ecologicamente correto.

Apesar desta pesquisa ter sido elaborada com apenas quatro agricultores familiares, assim não podendo generalizar os resultados apresentados, é explícita a contribuição do modo de produção deles e como é coeso com as dimensões da agroecologia presentes na literatura. Um limite conceitual da pesquisa foi a separação didática das dimensões para compararmos as respostas dos agricultores. Assim, um tema como canais de comercialização, que a priori deveria estar situado na dimensão econômica figurou na dimensão social por estar vinculado ao abastecimento local da 
forma como foi citado na literatura. As dimensões da agroecologia são holísticas e interdependentes, a forma como os dados foram apresentados configuram-se como uma escolha de apresentação das informações.

É mister que os conhecimentos empíricos e adquiridos pelo contexto das comunidades em que os agricultores familiares estão inseridos sejam estudados e ouvidos pelos pesquisadores acadêmicos. A construção do conhecimento agroecológico é mais ancestral, e de saber entender a natureza, do que a simples implantação da técnica em si.

O papel da mulher é fundamental na agricultura familiar, em muitos âmbitos dentro e fora da propriedade rural. As mulheres são responsáveis muitas vezes pelo planejamento da rotina, pelo planejamento financeiro e por toda a estrutura que o agricultor familiar tem para conseguir desenvolver outros trabalhos. Apesar dessa importância, essa temática de gênero não foi abordada pela pesquisa porque delimitamos as dimensões selecionadas para o estudo na dissertação. Assim apontamos como perspectiva de pesquisa, a identificação do papel da mulher em processos e dimensões da agroecologia.

A agroecologia tem como objetivo mudar o mundo pela forma como produzimos, consumimos, distribuímos, vendemos os alimentos. E também pela forma como nos relacionamos, com ética e responsabilidade social, econômica e política, uns com os outros. Muito além dos aspectos técnicos, a agroecologia propõe uma nova forma de viver nesse planeta. Tendo observado um pouco de perto o trabalho e o comprometimento desses quatro agricultores, há uma esperança de que a valorização do trabalho deles por meio de políticas públicas mais assertivas, a existência de mais espaços para a comercialização de seus produtos, assim como a divulgação dessa "nova" forma de produzir e comercializar possa impactar positivamente os rumos da nossa vida localmente, regionalmente e globalmente. 


\section{REFERÊNCIAS}

ABDO, M. T. V. N.; VALERI, S. V.; MARTINS, A. L. M. Sistemas agroflorestais e agricultura familiar: uma parceria interessante. Revista Tecnologia \& Inovação Agropecuária, 2009.

ALTIERI, M. Agroecologia: A dinâmica produtiva da agricultura sustentável. 4. Ed. Porto Alegre: Editora da UFRGS, 2004.

ALTIERI, M. Agroecologia: bases científicas para uma agricultura sustentável. 3 . ed. rev. ampl. São Paulo, Rio de Janeiro: Expressão Popular, AS-PTA, 2012.

ARL, V. Agroecologia: desafios para uma condição de interação positiva e coevolução humana na natureza. In: Desenvolvimento territorial e agroecologia. Orgs.: Alves, A.F; Carrijo, B.C.; Candiotto, L.Z.P. São Paulo: Expressão Popular, 2008.

ASSIS, R. L.; ROMEIRO, A. R. Agroecologia e agricultura orgânica: controvérsias e tendências. In: Desenvolvimento e Meio Ambiente. Curitiba, v. 6, p. 67-80, 2002.

BARUJA, J. E. A; DELLAI, W; BRANDÃO, J. D. Política nacional de agroecologia e produção orgânica: entre a abordagem agroecológica e a construção de uma política pública. Resumos do I Congresso Paranaense de Agroecologia. Pinhais/PR, 2014.

BETTI, P.; FENIMAN, E.; SCHNEIDER, T.; NIEDERLE, P. O consumo politizado como resposta à crise socioambiental: as justificativas sociais da compra de produtos orgânicos em feiras-livre de Curitiba. In: Agroecologia: Práticas, Mercados e Políticas para uma Nova Agricultura. Orgs.: Niederle, P. A; Almeida, L; Vezzani, F.M. Curitiba: Kairós, 2013.

BRASIL. Congresso Nacional. Lei $\mathrm{n}^{\circ}$ 11.326, de 24 de julho de 2006. Estabelece as diretrizes para a formulação da Política Nacional da Agricultura Familiar e Empreendimentos Familiares Rurais. Diário Oficial da União, Brasília, DF, 25 jul. 2006. Disponível em: http://www.planalto.gov.br/ccivil_03/_ato20042006/2006/lei/111326.htm. Acesso em: 30 jan. 2016.

BRASIL. Presidência da República. Decreto no 6.323, de 27 de dezembro de 2007. Regulamenta a Lei $\mathrm{n}^{\mathrm{o}} 10.831$, de 23 de dezembro de 2003, que dispõe sobre a agricultura orgânica, e dá outras providências. Diário Oficial da União, Brasília, DF, 28 dez. 2007. Disponível em: http://www.planalto.gov.br/ccivil_03/_ato20072010/2007/Decreto/D6323.htm. Acesso em 18 fev. 2016.

BRASIL. PRONAF: Buscando as raízes: agricultura familiar e reforma agrária. (Caderno de Capacitação, nº 01). Brasília: Gráfica e Editora Del Rey, 2002.

BRASÍlLIA. Lei $\mathrm{n}^{\circ}$ 4.752, de 07 de fevereiro de 2012. Dispõe sobre a criação do Programa de Aquisição da Produção da Agricultura - PAPA/DF e dá outras providências. Diário Oficial do Distrito Federal 8 de fev 2012. 
BUAINAIN, A.M; GUANZIROLI, C; SOUZA FILHO, H.M; BÁNKUTI, F.I. Peculiaridades regionais da agricultura familiar brasileira. In: SOUZA FILHO, H.M; BATALHA, M. O. (orgs.). Gestão integrada da agricultura familiar. São Carlos: EdUFSCar, 2005.

BUAINAIN, A.M; SOUZA FILHO, H. M. Agricultura familiar, agroecológica e desenvolvimento sustentável: questões para debate. Título II. Série III. Brasília: IICAA, 2006.

CANDIOTTO, L. Z. P.; CARRIJO, B. R.; OLIVEIRA, J. A. A agroecologia e as agroflorestas no contexto de uma agricultura sustentável. In: Desenvolvimento territorial e agroecologia. Orgs.: Alves, A.F; Carrijo, B.C.; Candiotto, L.Z.P. São Paulo: Expressão Popular, 2008.

CAPORAL, F.R. La extensión agraria del sector público ante los desafíos del desarrollo sostenible: el caso de Rio Grande do Sul, Brasil. Tese de Doutorado. Córdoba: 1998.

CAPORAL, F.R. Em defesa de um plano nacional de transição agroecológica: compromisso com as atuais e nosso legado para as futuras gerações. In: Agroecologia e os desafios da transição agroecológica. SAUER, S.; BALESTRO, M. V. (orgs.). São Paulo: Expressão Popular, 2009.

CAPORAL, F.R; COSTABEBER, J.A. Agroecologia: alguns conceitos e princípios. Brasília: MDA/SAF/DATER-IICA, 2004.

Agroecologia e Extensão Rural: Contribuições para o Desenvolvimento Rural Sustentável. Porto Alegre - RS: 2004.

Agroecologia e Extensão Rural: Contribuições para o Desenvolvimento Rural Sustentável. Brasília - DF: 2007.

CARNEIRO, M. J. Pluriatividade da agricultura no Brasil: uma reflexão crítica. In: A diversidade da agricultura familiar. SCHNEIDER, S (org.). Porto Alegre: Editora da UFRGS, 2006.

CEPAL-FAO-IICA. Fomento de circuitos cortos como alternativa para la promoción de la agricultura familiar. Boletim, 2014. Disponível em: http://repiica.iica.int/docs/b3372e/b3372e.pdf

CODEPLAN. Agricultura Familiar no Distrito Federal: Dimensões e Desafios. Brasília: 2015.

COMUNELLO, F. J. Os movimentos nos mercados: a formação dos circuitos agroecológico e orgânico. In: Resumos do $V$ Encontro Nacional da ANPPAS. Florianópolis: 2010.2 Disponível em: http://www.anppas.org.br/encontro5/cd/artigos/GT7-375-306-20100902224233.pdf

COSTA NETO, C. Relações entre agronegócio e agroecologia no contexto do desenvolvimento rural brasileiro. In: Campesinato e agronegócio na América Latina: 
a questão agrária atual. FERNANDES, B.M (org.). São Paulo: Expressão Popular, 2008.

DAROLT, M. R. Alimentos orgânicos: um guia para o consumidor consciente. Instituto Agronômico do Paraná. Londrina, 2007.

DAROLT, M. R. Circuitos Curtos de Comercialização de alimentos ecológicos: reconectando produtores e consumidores. In: Agroecologia: Práticas, Mercados e Políticas para uma Nova Agricultura. Orgs.: Niederle, P. A; Almeida, L; Vezzani, F.M. Curitiba: Kairós, 2013.

DIEHL, A. A; TATIM, D. C. Pesquisa em Ciências Sociais Aplicadas - Métodos e Técnicas. São Paulo: Prentice Hall, 2004.

DINIZ, J. D. A. S. et al. Conservação ambiental e aproveitamento econômico em áreas de reserva legal de agricultores familiares na região do cerrado. In: Políticas Agroambientais e Sustentabilidade: desafios, oportunidades e lições aprendidas. SAMBUICHI, R. H. R (et al. orgs). Brasília: IPEA, 2014.

EHLERS, E. Agricultura sustentável: origens e perspectivas de um novo paradigma. Guaíba: Agropecuária, 1999.

EMATER-DF/; SEAGRI-DF. Conjuntura Socioeconômica Rural do Distrito Federal em Números: 2009.

EMBRAPA. Marco referencial em agroecologia. Brasília-DF: Embrapa Informação Tecnológica, 2006.

FLICK, U. Uma introdução à pesquisa qualitativa. Porto Alegre: Bookman, 2004.

FLORES, M. X.; MACÊDO, M. M. C. Políticas para o novo mundo rural brasileiro. In: $O$ novo rural brasileiro: políticas públicas. Editores: CAMPANHOLA, C; GRAZIANO DA SILVA, J. Jaguariúna, SP: EMBRAPA Meio Ambiente, 2000.

GLIESSMAN, S. R. et al. Agroecología: promoviendo uma transición hacia la sostenibilidad. In: Ecosistema - Revista científica e técnica de ecologia y medio ambiente, 2007.

GONÇALVES, F. O.; ROLIM, M. F. S.; ROSA, T. M. Motivações para o consumo de alimentos orgânicos - Possibilidades do Distrito Federal. (Estudo) Codeplan, Brasília-DF, 2016.

GRAZIANO DA SILVA, J. O que é questão agrária. $18^{\circ}$ edição. Editora Brasiliense, 1994.

GRISA, C.; SCHNEIDER, S. Três gerações de políticas públicas para a agricultura familiar e formas de interação entre sociedade e estado no Brasil. Rev. Econ. Sociol. Rural (online), Brasília, v. 52, supl. 1, p. 125-146, 2014.

GUANZIROLI, C. E. et al. Agricultura familiar e reforma agrária no século XXI. Rio de Janeiro: Garamond, 2001. 
HOFFMANN, M. R. M. Sistemas agroflorestais para agricultura familiar: análise econômica. Dissertação de Mestrado. Faculdade de Agronomia e Medicina Veterinária, UnB. Brasília, 2013.

IBGE - Instituto Brasileiro de Geografia e Estatística. Censo Agropecuário 2006. Disponível

em: http://www.ibge.gov.br/home/estatistica/economia/agropecuaria/censoagro/agri_familia r_2006_2/default.shtm. Acesso em: 03 mar. 2016.

JACINTHO, C. R. S. A agroecologia, a permacultura, e o paradigma ecológico na extensão rural: uma experiência no Assentamento Colônia I. Dissertação de Mestrado. Centro de Desenvolvimento Sustentável, UnB. Brasília, 2007.

MACHADO, L. C. P. As necessidades humanas, os saberes, a utopia: a agroecologia, os cerrados e sua proteção. In: Agroecologia e os desafios da transição agroecológica. SAUER, S.; BALESTRO, M. V. (orgs.). São Paulo: Expressão Popular, 2009 .

MACHADO, L. C. P; MACHADO FILHO, L. C. P. A dialética da agroecologia Contribuição para um mundo com alimentos sem veneno. São Paulo: Expressão Popular, 2014.

MACHADO FILHO, L. C. P. [et al.] Transição para uma agropecuária agroecológica. In: Simpósio Brasileiro de Agropecuária Sustentável. Anais. Viçosa: Imprensa Universitária, 2010.

MARCONI, M.A; LAKATOS, E.M. Fundamentos de metodologia científica. São Paulo: Atlas, 2010.

MATTEI, L. Programa de aquisição de alimentos da agricultura familiar (PAA): antecedentes, concepção e composição geral do programa. Cadernos do CEAM, v. 7, p. 33-44, 2007.

MOLINA, M. G. Las experiencias agroecológicas y su incidencia em el desarrollo rural sostenible. La necesidad de uma agroecológica política. In: Agroecologia e os desafios da transição agroecológica. SAUER, S.; BALESTRO, M. V. (orgs.). São Paulo: Expressão Popular, 2009.

MORETTO, L.; SALLES DA SILVA, A. A experiência de transição agroecológica no Sítio Vida Verde em Ceilândia, Distrito Federal: os sistemas agroflorestais como resposta harmônica entre agricultura e meio ambiente. In: Resumos do IV Seminário de Agroecologia do Distrito Federal e Entorno. Brasília, 2014.

MOURA, M. R. H. [et al.] Agrofloresta pra todo lado. Emater-DF. Brasília, 2010.

MÜLLER, A. L. A construção das políticas públicas para a agricultura familiar no Brasil: o caso do programa de aquisição de alimentos. Dissertação (Mestrado em Desenvolvimento Rural). Porto Alegre: UFSC, 2007. 
NAVES, F. Construção, subversão e submissão: reflexões sobre estratégias de acesso ao mercado adotadas por agricultores familiares agroecológicos. In: $O$ campo em debate: terra, homens, lutas. SECRETO, M. V; CARNEIRO, M. J; BRUNO, R (orgs.) et alii. Rio de Janeiro: Mauad X; Seropédica, RJ: EDUR, 2008.

NIEDERLE, P. A.; ALMEIDA, L. A nova arquitetura dos mercados para produtos orgânicos: o debate da convencionalização. In: Agroecologia: práticas, mercados e políticas para uma nova agricultura. NIEDERLE, P. A.; ALMEIDA, L. A; VEZZANI, F. M. (orgs.). Curitiba: Kairós, 2013.

NIEDERLE, P. A.; ALMEIDA, L. e VEZZANI, F. M. (orgs.). Agroecologia: Práticas, Mercados e Políticas para uma Nova Agricultura. Curitiba: Kairós, 2013.

OLIVEIRA, M. N. S; WEHRMANN, M. E. S. F; SAUER, S. Agricultura familiar no Distrito Federal: a busca por uma produção sustentável. In: Sustentabilidade em debate. v. 06. N. 01. Brasília: 2015.

ORSI, S. D. Principais contribuições do programa de apoio às tecnologias apropriadas ao programa de verticalização da pequena produção agrícola no DF PROVE. In: Inovação nas tradições da agricultura familiar. LIMA, D.M.A; WILKINSON, J. (orgs.) Brasília: CNPQ/Paralelo 15, 2002.

PENEIREIRO, F. M. Fundamentos da agrofloresta sucessional. II Simpósio de Sistemas Agroflorestais. Sergipe, 2003.

PENEIREIRO, F. M. Sistemas agroflorestais dirigidos pela sucessão natural: um estudo de caso. Dissertação de Mestrado. Mestrado em Ciências. ESALQ/USP (1999).

PETERSEN, P. (org.). Introdução. In: Agricultura familiar camponesa na construção do futuro. Rio de Janeiro: AS-PTA, 2009.

SABOURIN, E.; THOMAS, S.; EGRET, L.; ÁVILA, M. L. Inovação social na comercialização de produtos orgânicos e agroecológicos da agricultura familiar no Distrito Federal. In: Sustentabilidade em debate. v. 05. n. 03. Brasília: 2014.

SACHS, I. Posfácio. In: Agricultura familiar e reforma agrária no século XXI. GUANZIROLI, C. E. et al. Rio de Janeiro: Garamond, 2001.

SANTOS, C. F.; ARAÚJO, I. T.; MAIA, Z. M. G. Agroecologia e Sustentabilidade para o espaço rural. Anais: ANPPAS, 2012. Disponível em: http://www.anppas.org.br/encontro6/anais/ARQUIVOS/GT7-1376-119520120630180622.pdf

SAQUET, A. A. Reflexões sobre a agroecologia no Brasil. In: Desenvolvimento territorial e agroecologia. Orgs.: Alves, A.F; Carrijo, B.C.; Candiotto, L.Z.P. São Paulo: Expressão Popular, 2008.

SAUER, S.; BALESTRO, M. V. (orgs.). Agroecologia e os desafios da transição agroecológica. São Paulo: Expressão Popular, 2009. 
SCARABELOT, M. Construção de Cadeias Agroalimentares Curtas e Papel dos Atores em Nova Veneza, SC. Dissertação de mestrado. UFRGS. Porto Alegre: 2012.

SCHMITT, C. J. Tecendo as redes de uma nova agricultura: um estudo socioambiental da Região Serrana do Rio Grande do Sul. Tese de doutorado. UFRGS. Porto Alegre: 2001.

SCHMITT, C. J. Transição agroecológica e desenvolvimento rural: um olhar a partir da experiência brasileira. In: Agroecologia e os desafios da transição agroecológica. SAUER, S.; BALESTRO, M. V. (orgs.). São Paulo: Expressão Popular, 2009.

SCHMITT, C. J.; GRISA, C. Agroecologias, mercados e políticas públicas: uma análise a partir dos instrumentos de ação governamental. In: Agroecologia: práticas, mercados e políticas para uma nova agricultura. NIEDERLE, P. A.; ALMEIDA, L. A; VEZZANI, F. M. (orgs.). Curitiba: Kairós, 2013.

SCHNEIDER, S. Introdução. In: A diversidade da agricultura familiar. SCHNEIDER, S (org.). Porto Alegre: Editora da UFRGS, 2006.

SCHNEIDER, S.; CONTERATO, M. A.; KOPPE, L. R.; SILVA, C. C. A pluriatividade e as condições de vida dos agricultores familiares do Rio Grande do Sul. In: A diversidade da agricultura familiar. SCHNEIDER, S (org.). Porto Alegre: Editora da UFRGS, 2006.

SOMARRIBA, E. Revisiting the past: an essay on agroforestry definition. Agroforestry Systems 19: 233-240. Kluwer Academic Publishers: Netherlands, 1992.

SOUZA FILHO, H.M; BATALHA, M. O. (orgs.). Gestão integrada da agricultura familiar. São Carlos: EdUFSCar, 2005.

THOMAS, S. Valorisation agro-alimentaire et commerciale des produits organiques. Etude de cas dans le District Fédéral, Brésil. Montpellier: Mémoire Istom, IRC Supagro, 2013.

VAN DER PLOEG, J. D. Agriculture in transition. Keynote Adress. Wageningem: 2008 (a).

VAN DER PLOEG, J. D. Camponeses e impérios alimentares: lutas por autonomia e sustentabilidade na era da globalização. Porto Alegre: UFRGS, 2008 (b).

WILKINSON, J. Mercados, redes e valores: o novo mundo da agricultura familiar. Porto Alegre: Editora da UFRGS, 2008. 


\section{APÊNDICE A \\ Entrevista semiestruturada com os agricultores familiares}

\section{Identificação}

1. Nome do entrevistado:

2. Idade:

3. Naturalidade:

4. Escolaridade:

5. Nome da propriedade:

6. Telefone:

\section{Bloco 1 - Resgate histórico}

a) O senhor se considera um agricultor de produção orgânica ou agroecológica? Ou os dois? Por que?

b) Quando e como iniciou a produção de orgânicos/agroecológicos?

c) Como esse tipo de produção aconteceu na prática? Fizeram algum curso/capacitação? Tiveram auxílio de alguém (outro agricultor/EMATER/consultoria)?

d) Qual a conjuntura agrícola, econômica e política da época?

\section{Bloco 2 - Dimensões da Agroecologia}

\subsection{Escala}

a) Quais os principais produtos comercializados?

b) Sabe quantos $\mathrm{kg} / \mathrm{caixas}$ são vendidos por mês desses produtos? Pode relatar?

c) Você tem o registro da quantidade dos produtos vendidos por mês dos últimos 05 anos? Houve aumento de escala na produção (sim/não)? Por quê?

\subsection{Social}

a) Quais foram os primeiros pontos de venda?

b) Como decidiram onde comercializar os produtos? Por quê?

c) Quais são os principais compradores? Venda direta (feira livre ou direto para o consumidor?) ou intermediários? Qual a sua opinião sobre os benefícios da venda direta/intermediária? Qual você prefere? Quais as dificuldades? 
d) Qual a relação com os consumidores? (no sentido de proximidade) Vocês conhecem os consumidores? Eles podem visitar a propriedade? (Como são organizadas essas visitas? Quantas pessoas? Grupos? Qual a finalidade da visita?)

\subsection{Política}

a) Alguma organização/entidade contribuiu de alguma forma para iniciar esse tipo de produção?

b) Participaram/participam de alguma política ou programa de governo de fomento a essa produção?

c) Faz parte de alguma associação que discute os princípios agroecológicos/ grupos de estudo/aperfeiçoamento?

d) Faz parte de alguma cooperativa/grupos de consumo (vendedor)?

\subsection{Econômica}

a) A venda dos produtos orgânicos/agroecológicos auxilia na renda familiar? É o principal dinheiro da família? Para onde você direciona o dinheiro recebido (na educação, alimentação, saúde e/ou para investimento na própria propriedade?)

b) O senhor consegue sempre oferecer o seu produto para o consumidor? Tem toda semana? Como é?

c) Como é sua organização em relação as culturas para sempre ter algum produto para a venda?

d) Você vende seus produtos da forma como são colhidos ou tem algum tipo de tratamento (descasque/lavagem/desfolhagem)? Embalagem, já vende cortadinho ou em porções? Como é?

e) Você acha que o seu consumidor valoriza esse tratamento? Como você percebe isso?

f) Vocês trabalham exclusivamente com as vendas dos produtos ou também trabalham com outras atividades?

g) Essas atividades que vocês fazem é para auxiliar na renda da família? Por que escolheram essas atividades? Hoje você gostaria de se manter nessa área 
(agricultura) (Sim/Não)? Por quê? Quais são suas perspectivas? Tem vontade de trabalhar em outra área?

\subsection{Ambiental}

a) Depois da transição/ruptura agroecológica ou depois do início da produção em sistemas orgânicos ou agroflorestais, perceberam que melhorou a produtividade por conta da inserção de novas espécies? E devido a crescente biodiversidade perceberam a diminuição de pragas e insetos?

b) Como era antes? E agora quantas espécies e cultivos possuem?

c) Houve redução do uso de ÁGUA (recursos naturais não renováveis)? Como é feito o uso da água na propriedade (aspersão, gotejamento e etc.)?

d) Há uso de maquinário agrícola (com motor)? Qual e por quê? Esse uso é estritamente necessário para a produção dos alimentos?

e) Há uma área de preservação ambiental na sua propriedade? Qual o tamanho? Qual a importância dessa área de preservação para você?

f) Há alguma área na propriedade que foi recuperada após a implementação de técnicas de sistema orgânicos ou agroecológicos? Qual e como? 


\section{APÊNDICE B \\ TERMO DE CONSENTIMENTO LIVRE E ESCLARECIDO}

Prezado (a) participante:

Sou estudante do mestrado em Meio Ambiente e Desenvolvimento Rural da Universidade de Brasília, Campus Planaltina. Estou realizando uma pesquisa sob supervisão das professoras Janaína Deane de Abreu Sá Diniz e Vânia Ferreira RoqueSpecht, cujo objetivo é identificar como se aplicam e desenvolvem os preceitos da Agroecologia na produção de agricultores familiares.

Sua participação envolve uma entrevista, que será gravada se assim você permitir, e que tem a duração aproximada duas horas.

A participação nesse estudo é voluntária e se você decidir não participar ou quiser desistir de continuar em qualquer momento, tem absoluta liberdade de fazê-lo.

Mesmo não tendo benefícios diretos em participar, indiretamente você estará contribuindo para a compreensão do tema estudado e para a produção de conhecimento científico.

Quaisquer dúvidas relativas à pesquisa poderão ser esclarecidas pelo(s) pesquisador(es), e-mail: nadia.lua@gmail.com ou janadiniz@unb.br.

Atenciosamente,

Nádia Silvério Oliveira Irineu

Brasília, / /2015.

Matrícula: 14/011089

Consinto em participar deste estudo e declaro ter recebido uma cópia deste termo de consentimento.

Agricultor Familiar

Brasília, / /2015. 